\title{
MICROCLIMA E OCORRÊNCIA DE RAMULOSE NO ALGODOEIRO EM DIFERENTES DENSIDADES POPULACIONAIS
}

\author{
JOSÉ EDUARDO BOFFINO DE ALMEIDA MONTEIRO
}

Dissertação apresentada à Escola Superior de

Agricultura “Luiz de Queiroz”, Universidade de São Paulo, para obtenção do título de Mestre em Agronomia, Área de Concentração: Física do Ambiente Agrícola.

P I R A C I C A B A

Estado de São Paulo - Brasil

Novembro - 2002 


\title{
MICROCLIMA E OCORRÊNCIA DE RAMULOSE NO ALGODOEIRO EM DIFERENTES DENSIDADES POPULACIONAIS
}

\author{
JOSÉ EDUARDO BOFFINO DE ALMEIDA MONTEIRO \\ Engenheiro Agrônomo
}

Orientador: Prof. Dr. PAULO CESAR SENTELHAS

\footnotetext{
Dissertação apresentada à Escola Superior de Agricultura "Luiz de Queiroz", Universidade de São Paulo, para obtenção do título de Mestre em Agronomia, Área de Concentração: Física do Ambiente Agrícola.
}

P I R A C I C A B A

Estado de São Paulo - Brasil

Novembro - 2002 


\section{Dados Internacionais de Catalogação na Publicação (CIP) DIVISÃO DE BIBLIOTECA E DOCUMENTAÇÃO - ESALQ/USP}

Monteiro, J osé Eduardo Boffino de Almeida

Mic roclima e ocorrência de ramulose no algodoeiro em diferentes densidades populaciona is / J osé Eduardo Boffino de Almeida Monteiro. - - Pira cicaba, 2002.

99 p. : il.

Dissertação (mestra do) - - Escola Superior de Agricultura Luiz de Queiroz, 2002. Bibliografia.

1. Algodão 2. Densidade populacional 3. Microclima 4. Práticas cultura is (Fitotécnica) 5. Ramulose 6. Va riedades vegeta is I. Título

CDD 633.51

"Permitida a cópia total ou parcial deste documento, desde que citada a fonte - $O$ autor" 
Aos meus pais, Manoel Antonio e Maria Cristina, pelo que sou hoje,

Dedico.

Aos meus irmãos, José Roberto, Alessandra e Beatriz,

À minha noiva, Tatiana, pelo exemplo de coragem e força de vontade,

Ofereço. 


\section{AGRADECIMENTOS}

Ao povo brasileiro que, em última instância, financiou a formação acadêmica, o projeto e, a bolsa de estudos por meio da CAPES.

Ao Prof. Dr. Paulo Cesar Sentelhas pelo exemplo profissional, orientação dedicada e, principalmente, pela grande amizade.

Ao Prof. Dr. Ederaldo José Chiavegato, pela atenção e grande participação no projeto e condução do experimento.

Ao Centro de Análise de Pesquisa Tecnológica do Agronegócio de Grãos e Fibras do Instituto Agronômico de Campinas (IAC).

Ao Centro de Pesquisa e Desenvolvimento de Fitossanidade do Instituto Agronômico de Campinas (IAC).

Ao amigo, Engenheiro Agrônomo Dr. Waldir Cintra de Jesus Júnior, pela grande colaboração.

Aos colegas e amigos de curso, não só pelo companheirismo mas, também, pelas exaustivas colaborações na fase experimental: Alaílson Santiago, Cristiane Guiselini, Evandro Righi, Fábio Marin, Felipe Pilau, Gustavo Lyra, Luciano Quaglia, Angélica Prela, Hélinton Pandorfi, e Rogério Cichota.

Ao Grupo de Estudos do Algodão (GEALG) e todos os seus integrantes que se contribuíram para a condução do experimento.

Aos professores, funcionários e colegas do Programa de Pós-Graduação em Física do Ambiente Agrí́cola do Departamento de Ciências Exatas, ESALQ/USP, pela amizade, colaboração e apoio.

Aos funcionários do Departamento de Produção Vegetal, ESALQ/USP, que auxiliaram em diversas atividades.

A todos aqueles que, direta ou indiretamente, contribuíram para a realização deste trabalho. 


\section{SUMÁRIO}

LISTA DE FIGURAS ........................................................................ vi

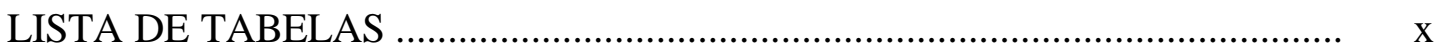

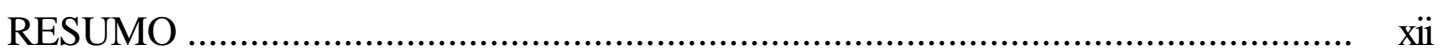

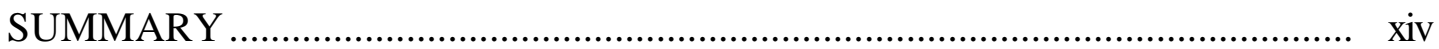

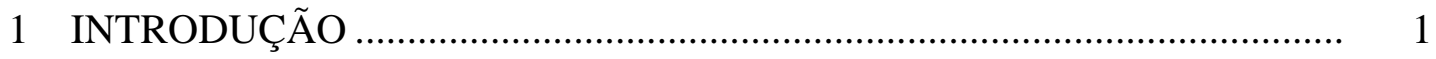

2 REVISÃO DE LITERATURA ............................................................. 4

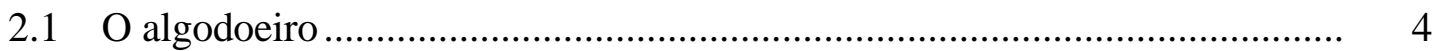

2.1.1 Densidade plantio ........................................................................ 5

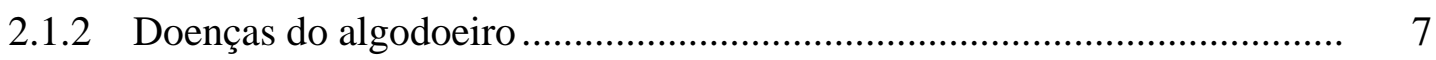

2.2 Condições meteorológicas e a ocorrência de doenças ............................... 10

2.2.1 Microclima da cultura ................................................................... 11

2.2.2 Temperatura ............................................................................. 13

2.2.3 Duração do período de molhamento ..................................................... 15

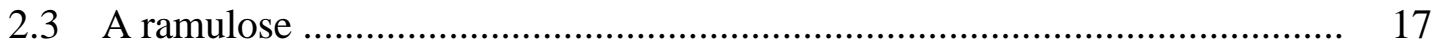

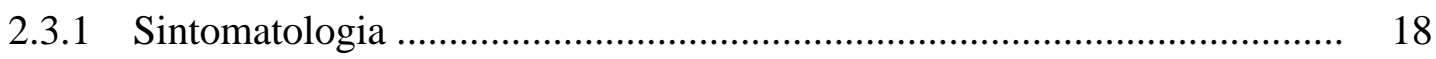

2.3.2 Disseminação e Epidemiologia ............................................................. 19

2.3.3 Progresso da ramulose e Controle .................................................... 20

3 MATERIAL E MÉTODOS .................................................................. 23

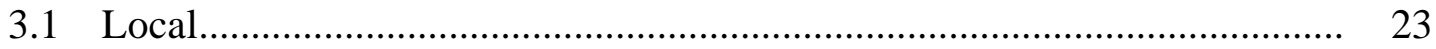

3.2 Cultura: Cultivares, Semeadura e Condução.............................................. 24

3.3 Inoculação e Avaliações da Doença .......................................................... 27

3.4 Avaliações Fitotécnicas ....................................................................... 29

3.4.1 Fases fenológicas....................................................................... 29

3.4.2 Desenvolvimento de um método de estimação da área foliar ................... 29

3.4.3 Altura de plantas, Massa Seca e Área Foliar .......................................... 31

3.4.4 Índice de Colheita e Produção................................................................. 32

3.5 Instrumentação e Monitoramento Agrometeorológico .............................. 33 
3.5.1 Estação Meteorológica …………………………................................. 33

3.5.2 Conjunto Sensor de Monitoramento Microclimático.................................. 34

3.5.2.1 Avaliação dos sensores de molhamento foliar ......................................... 35

3.5.3 Coleta e Análise dos Dados .................................................................... 36

4 RESULTADOS E DISCUSSÃO ……………………............................. 38

4.1 Análise de crescimento da cultura sadia ..................................................... 38

4.1.1 Massa seca e altura das plantas ........................................................... 38

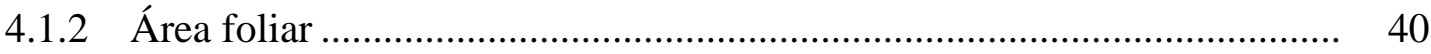

4.1.2.1 Desenvolvimento de um método de estimação da área foliar .................. 40

4.1.2.2 Índice de área foliar da cultura ao longo do ciclo .................................... 44

4.2 Microclima da cultura do algodoeiro …………………………………….. 45

4.2.1 Temperatura do ar ....................................................................... 46

4.2.2 Umidade relativa .............................................................................. 49

4.2.3 Duração do período de molhamento foliar (DPM) .................................... 51

4.2.3.1 Avaliação dos sensores de molhamento foliar ......................................... 51

4.2.3.2 Duração do período de molhamento foliar na cultura .............................. 53

4.3 Considerações gerais sobre o microclima da cultura ……………………….. 58

4.4 Ocorrência de ramulose na cultura do algodoeiro .......................................... 61

4.4.1 Curvas de Progresso da Doença ................................................................ 61

4.4.2 Área abaixo da curva de progresso da doença ........................................... 68

4.5 Relações entre o microclima da cultura e intensidade da doença ................. 71

4.6 Relações entre intensidade da doença e crescimento da cultura .................... 78

4.6.1 Massa seca e altura das plantas ................................................................. 78

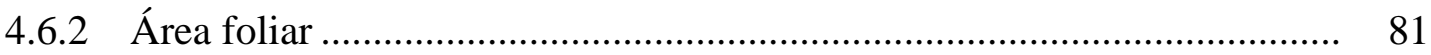

4.7 Relações entre intensidade da doença e a produção da cultura ...................... 84

5 CONCLUSÕES ............................................................................... 89

REFERÊNCIAS BIBLIOGR AFICAS _.......................................................... 92 


\section{LISTA DE FIGURAS}

Página

1 Ilustração esquemática da área experimental, distribuição dos tratamentos e equipamentos de monitoramento agrometeorológico.

2 Alguns sintomas da ramulose: lesões necróticas em forma de "estrela" com perfurações no limbo foliar e superbrotamento da região apical de um algodoeiro.

3 Contorno de imagens digitalizadas de folha jovem em expansão (a), folha cordiforme (b) e folha lobada expandida (c), com as indicações de seus respectivos comprimentos e larguras.

4 Conjunto sensor de monitoramento meteorológico na altura do terço superior das plantas.

5 Posicionamento do sensor eletrônico de molhamento foliar na altura do terço superior das plantas de algodoeiro.

6 Acúmulo de massa seca pelas cultivares de algodoeiro IAC 23 e Coodetec 401, testemunhas (T) - não inoculadas; de 0 a 150 dias após emergência (DAE), nas densidades de 5, 10 e 15 plantas por metro.

7 Altura média das plantas das cultivares de algodoeiro IAC 23 e Coodetec 401, testemunhas (T) - não inoculadas; de 0 a 150 dias após emergência (DAE), nas densidades de 5, 10 e 15 plantas por metro.

8 Relação entre os valores de área foliar do algodoeiro, estimados pelas dimensões das folhas e os valores de área foliar medidos, nas três classes de folhas avaliadas, para o algodoeiro.

9 Relação entre os valores de área foliar do algodoeiro, estimados pelas dimensões das folhas e os valores de área foliar medidos, nas três épocas avaliadas. 
10 Índice de área foliar das cultivares de algodoeiro IAC 23 e Coodetec 401, testemunhas (T) - não inoculadas; de 0 a 150 dias após emergência (DAE), nas densidades de 5, 10 e 15 plantas por metro.

11 Temperatura média do ar ao longo do ciclo da cultura do algodoeiro, medidas em cada densidade de plantio, na estação meteorológica da área experimental e no posto meteorológico (LCE/ESALQ/USP).

12 Temperatura do ar na cultura do algodoeiro e na estação meteorológica padrão, e velocidade do vento, ao longo do dia 02 de janeiro de 2002.

13 Umidade relativa média do ar ao longo do ciclo da cultura do algodoeiro, medidas em cada densidade de plantio, na estação meteorológica da área experimental e no posto meteorológico (LCE/ESALQ/USP).

14 Sinal elétrico de dois sensores de molhamento foliar, modelo 237 Campbell Scientific, instalados na cultura do algodoeiro nas seguintes condições: (a) sem pintura, dia 17/12/2001 e (b) com pintura, dia 17/03/2002.

15 Média diária da DPM, na cultura do algodoeiro, medida pelos sensores eletrônicos e estimada por NHUR $\geq 90 \%$, durante os 30 dias analisados. Barras com as mesmas letras não diferem estatisticamente entre si (Tukey a 5\%).

16 Duração do período de molhamento e precipitação em uma fase do ciclo da cultura do algodoeiro, medidas em cada densidade populacional, na estação meteorológica da área experimental e no posto meteorológico (LCE/ESALQ/USP).

17 Duração média do período de molhamento ao longo do ciclo da cultura do algodoeiro, medidas em cada densidade de plantio, na estação meteorológica da área experimental e no posto

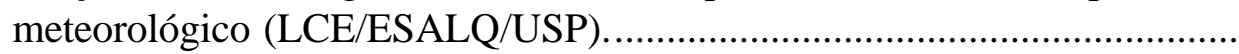

18 Duração nédia do período de molhamento, entre 0 e 60 DAE, em cada densidade de plantio e na estação meteorológica da área experimental. A linha pontilhada indica o período mínimo hipotético de molhamento necessário (12 h) para ocorrência de infecção entre 22 e $24^{\circ} \mathrm{C}$

19 Severidade média de ramulose na cultura do algodoeiro, nas parcelas inoculadas da cultivar IAC 23. 
20 Severidade média de ramulose na cultura do algodoeiro, nas parcelas inoculadas da cultivar Coodetec 401.

21 Taxa de crescimento da ramulose na cultura do algodoeiro, parcelas inoculadas, cultivares IAC 23 e Coodetec 401.

22 Incidência de ramulose, em valores percentuais na cultura do algodoeiro, nas parcelas inoculadas da cultivar IAC 23.

23 Incidência de ramulose, em valores percentuais na cultura do algodoeiro, nas parcelas inoculadas da cultivar Coodetec 401 .

24 Severidade de ramulose na cultura do algodoeiro, nas parcelas não inoculadas da cultivar IAC 23 (A) e Coodetec 401 (B).

25 Taxa de crescimento da ramulose no algodoeiro, parcelas não inoculadas, cultivares IAC 23 e Coodetec 401

26 Incidência de ramulose na cultura do algodoeiro, nas parcelas não inoculadas da cultivar IAC 23.

27 Incidência de ramulose na cultura do algodoeiro, nas parcelas não inoculadas da cultivar Coodetec 401.

28 Área abaixo da curva de progresso da ramulose no algodoeiro, cultivares IAC 23 e Coodetec 401, nas densidades de 5, 10 e 15 plantas por metro, parcelas inoculadas.

29 Área abaixo da curva de progresso da ramulose no algodoeiro, cultivares IAC 23 e Coodetec 401, nas densidades de 5, 10 e 15 plantas por metro, parcelas não inoculadas.

30 Variáveis meteorológicas registradas na área experimental nos dias que antecederam o maior aumento de incidência da ramulose no algodoeiro: a) DPM, UR e Precipitação; b) Temperatura e velocidade do vento.

31 Massa seca da cultura do algodoeiro, cultivares IAC 23 e Coodetec 401, nos tratamentos inoculados e testemunhas (T) - não inoculados; de 0 a 150 dias após emergência (DAE), nas densidades de 5, 10 e 15 plantas por metro.

32 Relação entre a área sob a curva de progresso da doença (AUDPC) e a massa seca (MS) aos 95 DAE, em todos os tratamentos e na média deles. Coeficientes de correlação não significativos para á $=0,05$. 
33 Área foliar ao longo do ciclo da cultura do algodoeiro, cultivares IAC 23 e Coodetec 401, inoculadas e testemunhas (T) não inoculadas, nas densidades de 5, 10 e 15 plantas por metro..........................

34 Duração da área foliar (DAF) da cultura do algodoeiro, cultivares IAC 23 e Coodetec 401, inoculadas e não inoculadas, nas densidades de 5,10 e 15 plantas por metro.

35 Rendimento de algodão em caroço, das cultivares IAC 23 e Coodetec 401, nas parcelas inoculadas e não inoculadas, nas densidades de 5, 10 e 15 plantas por metro.

36 Relação entre a área sob a curva de progresso da ramulose (AUDPC) e o rendimento de algodão em caroço, em todos os tratamentos e na média deles. Coeficientes de correlação significativos para á $=0,05$.

37 Redução percentual no rendimento de algodão em caroço, das cultivares IAC 23 e Coodetec 401, nas densidades de 5, 10 e 15 plantas por metro; parcelas inoculadas em relação às não inoculadas. 


\section{LISTA DE TABELAS}

Página

1 Importância potencial de doenças do algodoeiro em Estados produtores da região meridional do Brasil em $1999^{(1)}$

2 Dados médios mensais dos elementos meteorológicos em Piracicaba, SP. Período 1917 a 2000.

3 Tratamentos e respectivos números de repetições utilizadas.

25

4 Fases fenológicas do algodoeiro e correspondente época de ocorrência (DAE)

5 Resultados da análise de regressão entre o produto do comprimento pela largura $\left(\mathrm{C}^{*} \mathrm{~L}\right)$ das folhas e a área foliar medida, classificadas em três tipos de folhas do algodoeiro.

6 Ponderação do número de folhas agrupadas nas três classes definidas, em três momentos do ciclo da cultura do algodoeiro: 32, 65 e 95 dias após emergência.

7 Análise de regressão entre o produto do comprimento pela largura $\left(C^{*} \mathrm{~L}\right)$ das folhas e a área foliar medida, ponderando-se as classes de folhas aos 32, 65 e 95 dias após emergência.

8 Área sob a curva de progresso da ramulose no algodoeiro, cultivares IAC 23 e Coodetec 401, nas densidades de 5, 10 e 15 plantas por metro, parcelas inoculadas e não inoculadas.

9 Massa seca por parcela de algodoeiro, das cultivares IAC 23 e Coodetec 401 aos 90 DAE, nas densidades de 5, 10 e 15 plantas por metro, parcelas inoculadas e não inoculadas. 
10 Altura média das plantas de algodoeiro, cultivares IAC 23 e Coodetec 401 , inoculadas e não inoculadas.

11 Rendimento de algodão em caroço, em Kg. $\mathrm{m}^{-2}$, das cultivares IAC 23 e Coodetec 401, nas densidades de 5, 10 e 15 plantas por metro, nas parcelas inoculadas e não inoculadas.

12 Índice de colheita da cultura do algodoeiro, cultivares IAC 23 e Coodetec 401, nas densidades de 5, 10 e 15 plantas por metro, nas parcelas inoculadas e não inoculadas. 


\title{
MICROCLIMA E OCORRÊNCIA DE RAMULOSE NO ALGODOEIRO EM DIFERENTES DENSIDADES POPULACIONAIS
}

\author{
Autor: JOSÉ EDUARDO BOFFINO DE ALMEIDA MONTEIRO \\ Orientador: Prof. PAULO CESAR SENTELHAS
}

\section{RESUMO}

Com o objetivo de avaliar o microclima e a ocorrência de ramulose (Colletotrichum gossypii South. var. cephalosporioides Costa) em diferentes densidades populacionais do algodoeiro (Gossypium hirsutum L. var. latifolium Hutch.), foi conduzido um experimento com as cultivares IAC 23 e Coodetec 401, em espaçamento de $0,9 \mathrm{~m}$ entre linhas e com 5, 10 e 15 plantas por metro na linha de plantio, perfazendo um total de seis tratamentos, subdivididos em parcelas inoculadas e não inoculadas com o fungo. A temperatura do ar medida na altura do terço superior da cultura apresentou diferença significativa em relação à medida a $2 \mathrm{~m}$ do solo, na estação meteorológica, mas, não significativa entre as diferentes densidades. A umidade relativa foi maior quanto maior a densidade da cultura e significativamente menor na estação meteorológica. Porém, essa diferença ocorreu na fase inicial da cultura pois, a partir de um determinado grau de desenvolvimento, as diferenças entre densidades se minimizaram. A duração do período de molhamento (DPM) ocorreu de modo análogo à umidade relativa, porém com diferenças proporcionalmente maiores entre as densidades. Aos 30 dias após emergência (DAE), a DPM foi, em média, de 9,4, 10,2 e 11,7h, 
respectivamente, nas densidades de 5, 10 e 15 plantas por metro. Aos 45 DAE, a DPM foi de 11,2, 12,3 e 13,6h, nas mesmas densidades, respectivamente. Houve grande diferença de intensidade de doença entre as duas cultivares mas, não houve diferenças entre as três densidades, mesmo ocorrendo diferenças significativas entre os microclimas. Atribuiu-se a isso as condições macroclimáticas amplamente favoráveis ao patógeno, no decorrer do experimento. A área sob a curva de progresso da doença (AUDPC) nas parcelas inoculadas foi, em média, de 108 unidades na cultivar IAC 23 e 238 unidades na Coodetec 401. Nas não inoculadas, a AUDPC foi de 52 e 61 unidades, respectivamente. A duração da área foliar (DAF) entre 0 e 150 DAE, nas densidades de 5, 10 e 15 plantas por metro foi, respectivamente de 351, 502 e 645 IAF.dia na cultivar IAC 23, sem diferença entre parcelas inoculadas e não inoculadas. Na cultivar Coodetec 401, a DAF foi de 276, 482 e 606 IAF.dia nas parcelas não inoculadas, com redução de $8 \%$, 22\% e $20 \%$ nas parcelas inoculadas. Praticamente não houve diferença de rendimento de algodão em caroço entre as densidades. Na cultivar IAC 23 o rendimento foi de $0,42 \mathrm{Kg} \cdot \mathrm{m}^{-2}$ nas parcelas não inoculadas e de $0,36 \mathrm{Kg} \cdot \mathrm{m}^{-2}$ nas inoculadas. Na cultivar Coodetec 401, o rendimento foi de $0,44 \mathrm{Kg} \cdot \mathrm{m}^{-2}$ nas parcelas não inoculadas e de $0,24 \mathrm{Kg} \cdot \mathrm{m}^{-2}$ nas inoculadas. Com o monitoramento microclimático foi possível identificar um período bastante favorável à ocorrência da infecção, o qual precedeu um explosivo aumento de incidência da doença, próximo aos $87 \mathrm{DAE}$, que se caracterizou por um período com temperaturas noturnas menores, que $14^{\circ} \mathrm{C}-\mathrm{o}$ que aumenta o grau de predisposição do algodoeiro às doenças - seguido de dias com elevada umidade relativa do ar e DPM. 


\title{
MICROCLIMATE AND OCURRENCE OF RAMULOSE IN DIFFERENT COTTON PLANT POPULATION DENSITIES
}

\author{
Author: JOSÉ EDUARDO BOFFINO DE ALMEIDA MONTEIRO \\ Adviser: Prof. PAULO CESAR SENTELHAS
}

\section{SUMMARY}

With the goal of evaluating the microclimate and the occurrence of ramulose (Colletotrichum gossypii South. var. cephalosporioides Costa) in cotton (Gossypium hirsutum L. var. latifolium Hutch.) crop with different population densities, it was conducted an experiment with the genotypes IAC 23 and Coodetec 401, in the spacing of $0.9 \mathrm{~m}$ between lines and with 5, 10 and 15 plants per meter in the planting line, performing a total of six treatments, subdivided in areas, inoculated and not inoculated with the pathogen. The air temperature, measured within the crop canopy was significantly different from the measure obtained at $2 \mathrm{~m}$ in a weather station but it was not significantly different among densities. The relative humidity increased with the crop density and was larger at the crop level than at the weather station. However, the difference among densities occurred in the initial phase of development, being minimized with the crop growth. The wetness period presented variation similar to the relative humidity, however, with larger differences between densities. At 30 days after emergence of seedlings (DAE), wetness period was 9.4, 10.2 and $11.7 \mathrm{~h}$, 
respectively, in the densities of 5, 10 and 15 plants per meter. At 45 DAE, wetness period was $11.2,12.3$ and $13.6 \mathrm{~h}$, at the same densities, respectively. There was huge difference of disease intensity between genotypes but there was no difference between the three densities, even occurring significant differences in the microclimate. This was attributed to the macroclimatic conditions which were widely favorable to the pathogen during the experiment period. The area under disease progress curve (AUDPC) in the inoculated areas was, on the average, 108 units in the genotype IAC 23 and 238 units in Coodetec 401. In the not inoculated areas, it was 52 and 61 units, respectively. The duration of the leaf area (DAF) between 0 and 150 DAE, in the densities of 5, 10 and 15 plants per meter was, respectively, 351, 502 and 645 LAI.day in the genotype IAC 23, without difference between inoculated and not inoculated areas. In the genotype Coodetec 401, DAF was 276, 482 and 606 LAI.day in the not inoculated areas, occurring reduction of $8 \%, 22 \%$ and $20 \%$ in the inoculated ones. There was no difference in the cotton yield between densities. In the genotype IAC 23 the yield was $0.42 \mathrm{Kg} \cdot \mathrm{m}^{-2}$ in the not inoculated areas and $0.36 \mathrm{Kg} \cdot \mathrm{m}^{-2}$ in the inoculated ones. In the genotype Coodetec 401 , the yield was $0.44 \mathrm{Kg} \cdot \mathrm{m}^{-2}$ in the not inoculated areas and 0.24 $\mathrm{Kg} \cdot \mathrm{m}^{-2}$ in the inoculated. With the daily evaluation of the microclimate conditions it was possible to identify a favorable period to the pathogen infection, which preceded an explosive increase of the disease incidence, near to 87 DAE, which was characterized for a period with smaller nocturnal temperatures, under $14^{\circ} \mathrm{C}$ - what increases the predisposition degree of the cotton to diseases - followed by days with high air relative humidity and wetness period. 


\section{INTRODUÇÃO}

A cotonicultura no Brasil consolidou sua recuperação em termos de produção e até mesmo de inserção nos mercados internacionais, no ano de 2001. Depois de anos de estagnação do setor produtivo e de chegar a ser um dos maiores importadores mundiais da fibra, o Brasil volta a exportar volume significativo.

A explosão da cultura do algodão no Centro-Oeste e em certas regiões do Norte e Nordeste do Brasil representou a migração da cultura para novas áreas, as quais, livres de certas pragas e doenças e com clima mais favorável, permitiam certas vantagens comparativas, em relação às áreas tradicionais. Representou também, uma profunda mudança nos paradigmas básicos da cultura, na medida em que mudou completamente a escala de produção, o sistema de produção e o processo administrativo.

O consumo nacional de algodão em pluma no ano 2000 foi em torno de 949 mil toneladas, cerca de $25 \%$ maior que no início da década anterior, enquanto que no mesmo período o consumo médio mundial aumentou 7\%. No entanto, apesar dos bons resultados dos últimos anos, a cotonicultura brasileira também enfrenta difíceis problemas como a dificuldade de acesso a mercados internacionais, com enorme aparato de subsídios e barreiras comerciais (FNP, 2002). Além disso, os cotonicultores começam a enfrentar custosos problemas com doenças, como a ramulária, até então inexpressiva, ou mesmo inexistente, nas novas áreas produtoras (Chiavegato, 2001; Chiavegato ${ }^{1}$ ).

Se as perspectivas para o mercado de algodão no final de 2001 e ao longo de 2002 não tem sido favoráveis, é preciso, contudo, ter em mente que a atividade, nas bases em que se firma no Brasil, é altamente viável e as atuais dificuldades são meramente conjunturais.

\footnotetext{
${ }^{1}$ CHIAVEGATO, E.J. Comunicação pessoal, 2002.
} 
Visto o mercado sob este prisma, são altamente positivas as iniciativas como a do Proalba (Programa de Incentivo à Cultura do Algodão no Cerrado Baiano), que pretende estimular a expansão da cultura, tomando por base os princípios de eficiência produtiva, ou seja, mediante a combinação de baixos custos com elevada qualidade da fibra. O programa prevê investimentos em pesquisa para elevar a produtividade, com o desenvolvimento de novos cultivares e tecnologias de controle de pragas e doenças (FNP, 2002), atualmente um dos principais problemas da cultura.

No caso do algodoeiro, encontram-se registrados na literatura especializada mais de 250 espécies de agentes causais de doenças. É certo que muitas dessas doenças não apresentam qualquer importância econômica, porém, outras são altamente destrutivas. O método mais econômico e seguro de controle de doenças é o emprego de cultivares resistentes. Todavia, nem sempre existem fatores de resistência no germoplasma disponível ou o material não apresenta resistência múltipla às principais doenças que ocorrem na região ou, ainda, por opção de produtores - por razões técnicas ou econômicas diversas - pelo plantio de cultivares suscetíveis (Cia \& Fuzatto, 1999).

Cia e Fuzatto (1999), classificando a importância potencial de doenças de algodoeiro, até o ano de 1999, em Estados produtores da região meridional do Brasil, responsável por $92 \%$ da produção nacional, identificou a ramulose como a de maior importância dentre as doenças fúngicas e bacterianas, principalmente no cerrado.

Esta doença foi constatada pela primeira vez no município de Rancharia, SP, em 1936, e já se encontra disseminada praticamente por todas as regiões do país onde se cultiva o algodoeiro. Atualmente, vem causando problemas sérios nos Estados de Goiás, Mato Grosso do Sul, Mato Grosso e em algumas localidades do Nordeste brasileiro (Cia \& Salgado, 1995).

Sabe-se que o desenvolvimento de uma doença é resultante da interação de uma planta suscetível com um agente patogênico e fatores ambientais favoráveis. $\mathrm{O}$ ambiente, portanto, é um componente relevante nesta interação, podendo, inclusive, impedir a ocorrência de doença mesmo na presença de hospedeiro suscetível e do patógeno. Doenças altamente destrutivas, em ambiente favorável, podem passar desapercebidas, sob certas condições ambientais (Bedendo, 1995). 
Mais especificamente, Pereira et al. (2002) salientam que a ocorrência de doenças em plantas é determinada primeiramente pelo macroclima, seguido pelo topo e depois, microclima; e que o uso de práticas agrícolas podem provocar alterações no microclima de uma cultura, fazendo com que a região ou local passe de pouco favorável para altamente favorável para determinadas doenças. Uma das práticas agrícolas que provocam alterações acentuadas no microclima, e provavelmente a mais comum na cultura do algodoeiro, é o uso de diferentes densidades de plantio.

Segundo Cia \& Salgado (1995), condições favoráveis ao desenvolvimento da ramulose são: alta pluviosidade, boa fertilidade de solo e temperatura entre $25^{\circ}$ e $30^{\circ} \mathrm{C}$.

No entanto, a simples noção geral sem a quantificação precisa das condições que favorecem o desenvolvimento desta doença proporciona poucos resultados práticos. Logo, demanda-se aprofundamento nos estudos das relações entre as condições meteorológicas, mais precisamente do microclima da cultura, e a epidemiologia desta doença. A determinação mais acurada dessas relações cria a oportunidade de desenvolvimento de métodos ou modelos que identifiquem as situações ou momentos em que a ocorrência ou agravamento da doença é iminente.

Em resumo, é essencial , inicialmente, gerar conhecimento básico mais detalhado sobre a interação entre a ramulose e o microclima do algodoeiro para se fundamentar estudos futuros mais específicos, a fim de se viabilizar a criação de um sistema de previsão desta doença, e até mesmo como subsídio para outras doenças desta cultura. Nesse sentido, os principais objetivos deste trabalho foram avaliar o efeito de diferentes densidades populacionais de duas cultivares de algodoeiro, IAC 23 e Coodetec 401, no:
a) crescimento das plantas;
b) microclima da cultura;
c) intensidade da ramulose $\mathrm{e}$
d) componentes de produção. 


\section{REVISÃO DE LITERATURA}

\subsection{O algodoeiro}

O algodoeiro herbáceo (Gossypium hirsutum L. var. latifolium Hutch.) é um dos fitossistemas de maior complexidade que a natureza criou, tendo hábito de crescimento indeterminado (Oosterhuis, 1999), apresentando pelo menos dois tipos de ramificação (monopodiais e simpodiais), dois tipos de folhas verdadeiras (dos ramos e dos frutos) e pelo menos duas gemas (axilar e extra-axilar) situadas na base de cada folha (Mauney, 1984), o que, junto com outros apanágios morfológicos e fisiológicos, conferem a esta planta uma elevada plasticidade fenotípica, ajustando-se aos mais diversos ambientes de clima e solo, sendo atualmente cultivado em cerca de 33 milhões de hectares, em áreas de latitude entre de $40^{\circ} \mathrm{N}$ e $30^{\circ} \mathrm{S}$, sendo que mais de $50 \%$ da área plantada é sob irrigação (Amorin Neto e Beltrão, 1999; Beltrão e Souza, 2001).

A planta apresenta metabolismo fotossintético $\mathrm{C}_{3}$, tendo elevadas taxas de fotorespiração, apesar de ser heliófita, não se saturando em condições de campo, mesmo com o máximo de radiação solar de cerca de $1000 \mathrm{~W} \cdot \mathrm{m}^{-2}$ ou $2000 \mu \mathrm{E} \cdot \mathrm{m}^{-2} \cdot \mathrm{s}^{-1}$, tendo estrutura do dossel planofoliar, com elevadíssimo coeficiente de extinção de luz (Baker et al., 1972 e Benedict, 1984). A taxa de crescimento da cultura (TCC) do algodoeiro herbáceo é baixa, variando em torno de $15 \mathrm{~g} \cdot \mathrm{m}^{-2} \cdot \mathrm{dia}^{-1}$, tendo elevado consumo de água para produção de fitomassa, média de $646 \mathrm{~g}$ de água por grama de fitomassa. Pode chegar a uma produtividade potencial de $16.500 \mathrm{~kg} \cdot \mathrm{ha}^{-1}$ de algodão em caroço, ou 300 frutos. $\mathrm{m}^{-2}$, caso não houvesse a queda das estruturas de reprodução ou "shedding"

(Hearn, 1973). Para o cultivo do algodoeiro, o estabelecimento da melhor época de semeadura em conformidade com o zoneamento agroecológico é de extrema importância, em razão da sensibilidade que a espécie possui frente à variação das 
condições ambientais (Lazzarotto et al., 2001; Chiavegato, 1995). Por isso, a semeadura é aconselhável em regiões ou épocas em que as temperaturas permaneçam entre 18 e $30^{\circ} \mathrm{C}$, nunca ultrapassando o limite inferior de $14^{\circ} \mathrm{C}$ e superior de $40^{\circ} \mathrm{C}$. Dependendo do clima e da duração do ciclo, o algodoeiro necessita de 700 a $1.300 \mathrm{~mm}$ de chuva para atender suas necessidades de água; 50 a 60\% dessa água é necessária durante o período de floração (50 a 70 dias), quando a massa foliar está completamente desenvolvida. Um déficit hídrico capaz de reduzir $50 \%$ a evapotranspiração relativa nesse período pode significar a redução no rendimento de algodão na ordem de 28 a 45\%, dependendo da duração do déficit (Doorenbos et al., 1979).

\subsubsection{Densidade plantio}

A população de plantas ideal de uma cultura por unidade de área é um dos

componentes de produção que contribui significativamente para o aumento da produtividade (Jadhao et al., 1993; Heitholt, 1994).

A resposta do algodoeiro em relação à população é complexa, e envolve aspectos ecofisiológicos (Lamas \& Staut, 2001). Vários são os fatores que influenciam na definição do melhor espaçamento entre fileiras, podendo-se destacar: cultivar, clima, fertilidade do solo e sistemas de cultivo e de colheita (Laca-Buendia \& Faria, 1982).

Os resultados de pesquisas desenvolvidas com o algodoeiro, nas mais diferentes regiões, tanto no exterior como no Brasil, não são consistentes no que se refere a melhor população de plantas, por ser o algodoeiro uma espécie com boa plasticidade morfológica, quando se analisa apenas o aspecto quantitativo da produção (Staut \& Lamas, 1999).

A produção de algodão em caroço é mais influenciada pelo espaçamento entre fileiras, e as características tecnológicas da fibra pela densidade de plantio na linha. Bednarz et al. (2000), estudando o efeito da densidade de 3,5 a 25,1 sementes. $\mathrm{m}^{-2}$, com espaçamento entre fileiras de $91 \mathrm{~cm}$, não encontraram diferenças significativas entre as densidades, para a variável produção de algodão em caroço. Jost \& Cothren (2000) relatam que o comprimento da fibra tende a ser menor com a redução do espaçamento 
entre fileiras.

Um dos motivos que tem levado a uma tendência de redução do espaçamento entre fileiras e aumento da densidade de plantas é demonstrado por Jost \& Cothren (2000), que concluíram ser possível reduzir o custo de produção sem alterar significativamente a produção de fibra. Segundo Azevêdo et al. (1994), o espaçamento entre fileiras pode se constituir em uma importante tática para o controle de plantas daninhas, pois a duração e o início do período crítico de competição é função do espaçamento. Por outro lado, em espaçamentos reduzidos, a qualidade da fibra é sensivelmente deteriorada. Desse modo, ainda são necessárias novas pesquisas para consolidar este novo sistema de produção (Lamas \& Staut, 2001).

Segundo Thompson (1999), nos Estados Unidos, o uso de plantios adensados, com espaçamento reduzido a $76 \mathrm{~cm}$, aumentam de 10 a $15 \%$ o rendimento da cultura. Alguns produtores têm obtido resultados ainda melhores, em torno de $25 \%$ de aumento de produção com manejo diferenciado. Por outro lado, Heitholt et al. (1996), comparando genótipos de algodão plantados em espaçamento de 76 e $102 \mathrm{~cm}$ entre linhas verificou que isso não resultou em diferenças de rendimento pois, embora, a cultura em espaçamento de $76 \mathrm{~cm}$ tenha absorvido, na média, 9\% mais radiação fotossinteticamente ativa, as áreas menos densas atingiam as mesmas taxas de absorção poucos dias depois.

Tem sido proposto que os genótipos mais adequados para serem plantados com $76 \mathrm{~cm}$ entre linhas devem exibir diferente morfologia e arquitetura de dossel do que os genótipos selecionados para 102cm entre linhas (Kerby et al., 1988; Kerby et al., 1990a,b). As características dos genótipos que tem sido indicados para render melhor em $76 \mathrm{~cm}$ entre linhas incluem pequeno porte e ciclo curto. Tais genótipos não são capazes de estabelecer porte e área foliar suficiente para fechar o dossel em $102 \mathrm{~cm}$ entre linhas, mas são adaptados a fazê-lo em $76 \mathrm{~cm}$.

Na realidade, a população de plantas de algodão deve ser controlada a fim de se atingir a máxima interceptação de luz, mas populações maiores que isso podem reduzir o rendimento. Acima de 150.000 plantas por hectare, por exemplo, a intensificação da competição intraespecífica reduz a produção. Populações 
recomendadas são de 70.000 a 125.000 plantas por hectare. Isto requer uma densidade de 9 a 12 plantas por metro em linhas espaçadas de $96 \mathrm{~cm}$ para algodão irrigado e 6 a 9 plantas para áreas de sequeiro (Thompson, 1999).

Para as condições de Mato Grosso e Mato Grosso do Sul, considerando-se as cultivares atualmente recomendadas, a população de plantas deve estar entre 80.000 a 120.000 plantas por hectare. O espaçamento entre fileiras deve ser de 80 a $90 \mathrm{~cm}$, com 8 a 12 plantas por metro. Para a definição do espaçamento utilizado, deve-se levar em consideração se a colheita será manual ou mecanizada. No caso de colheita mecanizada, o espaçamento entre fileiras deverá, em primeiro lugar, obedecer ao espaçamento das "bocas" da colhedora. Deve-se, também, levar em conta que o número de linhas da semeadora deverá ser igual ao número de "bocas" da colhedora ou, pelo menos, obedecer a seus múltiplos (Lamas \& Staut, 2001).

\subsubsection{Doenças do algodoeiro}

Como acontece em outras culturas, às doenças constituem uma das causas de grandes perdas na cultura do algodoeiro em todas as regiões produtoras. É difícil estimar com exatidão os prejuízos causados pelas diversas doenças, porém, os que lidam com a cultura são unânimes ao afirmar que a queda de rendimento e sua influência na qualidade da fibra são grandes. Levantamentos realizados nas regiões produtoras dos Estados Unidos entre 1953 e 1977 (Watkins, 1981) mostraram que, em média, o somatório dos efeitos de todas as doenças causaram danos de 10,5\% (1974) a 20,4\% (1961).Wang \& Davis (1997) relatam perdas de cerca de 180 mil toneladas apenas devido a doenças de plântulas (tombamento) no ano de 1995.

No Brasil não existem dados precisos sobre os efeitos somados de todas as doenças sobre a produção de pluma; há apenas relatos de danos decorrentes da ação de patógenos, individualmente. Entretanto, como muitos patógenos da cultura ocorrem nas regiões produtoras (Cia \& Salgado, 1995), estima-se que as perdas sejam substanciais. Quando grandes áreas produtoras de algodão se fixaram na região do Cerrado, lá encontraram condições de ambiente amplamente favoráveis à cultura e, 
também, ao desenvolvimento dos principais patógenos; tem sido constatada alta incidência de doenças foliares, inclusive aquelas consideradas, até então, de pouca importância para o algodoeiro. Segundo Chiavegato (2001), os cotonicultores começam a enfrentar custosos danos provocados por doenças nas regiões do Cerrado, como os da ramulária, até então inexpressiva nas áreas tradicionalmente produtoras e, inexistente nas novas áreas, principalmente na Região Centro-Oeste.

$\mathrm{Na}$ Tabela 1 foram estabelecidas notas de 1 a 5 para a importância potencial da doença, desconsiderando-se o emprego de medidas de controle, principalmente o uso de cultivares resistentes, nas principais regiões produtoras brasileiras.

Tabela 1. Importância potencial de doenças do algodoeiro em Estados produtores da região meridional do Brasil em $1999^{(1)}$.

\begin{tabular}{lccccccc}
\hline \multirow{2}{*}{ Doença } & \multicolumn{9}{c}{ Estados Produtores } & \multicolumn{2}{c}{} \\
& PR & SP & MG & GO & MT & MS & Total \\
\hline Murcha de Fusarium (fungo) & 4 & 5 & 3 & 3 & 1 & 2 & 18 \\
Murcha de Verticillium (fungo) & 3 & 3 & 1 & 1 & 1 & 1 & 10 \\
Mancha Angular (bactéria) & 4 & 3 & 3 & 3 & 3 & 3 & 19 \\
Outras manchas foliares & 3 & 2 & 2 & 3 & 4 & 3 & 17 \\
ramulose (fungo) & $\mathbf{3}$ & $\mathbf{3}$ & $\mathbf{4}$ & $\mathbf{5}$ & $\mathbf{5}$ & $\mathbf{4}$ & $\mathbf{2 4}$ \\
Nematóides & 4 & 5 & 4 & 3 & 2 & 2 & 20 \\
Doença Azul (vírus) & 4 & 5 & 5 & 5 & 5 & 5 & 29 \\
Murchamento avermelhado (vírus) & 4 & 5 & 3 & 3 & 3 & 3 & 21 \\
\hline
\end{tabular}

Fonte: Chiavegato (2001) modificado de Cia \& Fuzatto (1999).

(1) Escala de notas: 1 = sem importância; 2 = pequena importância; 3 = medianamente importante, necessitando de precauções e estudos; 4 = importante, demandando medidas de controle; $5=$ muito importante, inviabilizando a cultura se não houver controle.

Dentre as principais doenças do algodoeiro no Brasil, listadas na Tabela 1, destaca-se a ramulose, agente causal Colletotrichum gossypii var. cephalosporioides como a de maior importância dentre todas as doenças fúngicas e bacterianas, principalmente no Cerrado. Cia et al. (2001) relatam o esquema utilizado para obtenção 
da cultivar IAC 21 realizado no período de 1981/82 a 1993/94. O melhoramento da cultivar foi direcionado principalmente para resistência a Colletotrichum gossypii var. cephalosporioides e nematóides, destacando-se a importância desta doença fúngica e os esforços na tentativa de se contornar os prejuízos por ela causados.

Por outro lado, se até meados de 1999 a ramulose era considerada a doença mais importante do algodoeiro, mais recentemente, a ramulária tem elevado os custos de produção de algodão, devido às medidas de controle que tem demandado. Nesses casos, a ramulose passou a ter importância secundária, uma vez que acaba sendo também controlada pelas medidas adotadas no controle da ramulária, geralmente, pulverizações com fungicidas (Chiavegato ${ }^{2}$ ).

O patógeno causador da ramulose tem na semente o seu principal veículo de transmissão e disseminação, onde pode estar presente tanto externa quanto internamente. Este fungo pode sobreviver no solo de uma safra para outra, sendo também considerado causador de tombamento de pré e pós-emergência de plântulas (Watkins, 1981).

O principal método de controle de doenças do algodoeiro consiste na utilização de cultivares resistentes. Todavia, para certos patógenos não se dispõe de genótipos com essa propriedade e, por outro lado, mesmo que se use material resistente, é sempre conveniente complementar essa medida com outras de natureza diversa. $\mathrm{O}$ ideal, de fato, seria combinar também medidas de profilaxia, além de técnicas culturais. O uso de defensivos no controle de doenças do algodoeiro, considerando tanto a eficiência como os aspectos econômicos, está restrito a condições especiais. Na prática, ele está associado à ausência, nas cultivares disponíveis, de resistência genética a certas doenças e, também, a opção de produtores - por razões técnicas ou econômicas diversas - pelo plantio de cultivares suscetíveis (Cia \& Fuzatto, 1999).

${ }^{2}$ CHIAVEGATO, E.J. Comunicação pessoal, 2002. 


\subsection{Condições meteorológicas e a ocorrência de doenças}

O produto final do algodoeiro, em quantidade e qualidade, é função de uma série de fatores que atuam a cada momento sobre o desenvolvimento das plantas (Silva, 1972). O ambiente - definido como o conjunto de condições e fatores adversos ou favoráveis, presentes no local de cultivo - constitui-se em variável importantíssima que, em qualquer fase do desenvolvimento, pode atuar modificando a produção e a qualidade do produto final (Chiavegato, 1995).

Chiavegato (1995), estudando o efeito do ambiente e de cultivares nos componentes da produção e nas características tecnológicas da fibra e do fio de algodão, concluiu que a influência do ambiente na produção de algodão em caroço foi dez vezes maior à de cultivar. Essa grande influência de ambientes na produção é esperada e explicada pela grande variação entre locais e anos quanto às condições edafoclimáticas regionais e a fatores adversos tais como pragas, doenças, nematóides, deficiências nutricionais, condições meteorológicas e técnicas de cultivo.

Segundo Bedendo (1995), o desenvolvimento e a produção de uma espécie vegetal dependem do seu genótipo e das condições ambientais que direta ou indiretamente podem atuar sobre suas características. Elementos do clima como umidade, temperatura, luz e vento, podem ser responsáveis pela predisposição de plantas ao ataque de patógenos. Como conseqüência, o desenvolvimento vegetativo e produtivo destas plantas é prejudicado, mesmo que o potencial genético para estes caracteres seja elevado.

O desenvolvimento de uma doença é resultante da interação entre uma planta suscetível, um agente patogênico e condições ambientais favoráveis. O ambiente, portanto, é um componente relevante nesta interação, podendo, inclusive, impedir a ocorrência da doença mesmo na presença de hospedeiro suscetível e de fonte de inóculo. Doenças altamente destrutivas em ambiente favorável, podem passar desapercebidas, sob certas condições ambientais (Bedendo, 1995; Bergamin Filho \& Amorim, 1996). 


\subsubsection{Microclima da cultura}

Segundo Rotem \& Palti (1969), o microclima de uma cultura é determinado pela densidade de plantio, topografia, tipo de solo, drenagem e fatores culturais, como a irrigação.

$\mathrm{O}$ incremento da densidade populacional de uma cultura afeta marcadamente o balanço de energia radiante e, conseqüentemente, a velocidade de evaporação de água proveniente de chuva, orvalho ou irrigação (Pedro Jr., 1989). Isso resulta em alterações microclimáticas que afetam o curso diário da umidade e da temperatura dentro do dossel das plantas, favorecendo o desenvolvimento de epidemias (Rotem \& Palti, 1969 e Pedro Jr., 1989).

As doenças de plantas provocadas por fungos que atacam folhas e frutos são influenciadas, principalmente, pelo macroclima da região. Porém, o uso de técnicas agrícolas como sombreamento, quebra-ventos, cobertura morta do solo, densidade de plantio e irrigação, podem modificar o microclima da comunidade vegetal, alterando o curso diário da temperatura e da umidade do ar influindo decisivamente na instalação do processo infeccioso e no desenvolvimento epidemiológico, por suas inter-relações com o patógeno (Pedro Jr., 1989).

Entre os elementos meteorológicos que influenciam o desenvolvimento do hospedeiro e patógeno, podem ser citados como principais: umidade do ar, temperatura, precipitação pluvial e vento (Zahler et al., 1991). A observação contínua dessas variáveis, bem como as da cultura e do patógeno são necessários para melhor entendimento e quantificação dessas inter-relações (Sutton et al., 1984).

A exposição da cultura a condições climáticas diferentes daquelas às quais ela é usualmente submetida pode ocasionar mudanças no comportamento de determinados patossistemas. Muitas vezes, apesar da cultura estar exposta a um ambiente supostamente adverso à doença, epidemias continuam a ocorrer (Rotem, 1988). Isso ocorre porque técnicas de cultivo intensivo podem transformar ambientes adversos em ambientes favoráveis ao desenvolvimento de doenças. Doenças de plantas geralmente ocorrem sob ampla faixa de condições ambientais. No entanto, a extensão e a 
freqüência da ocorrência de determinada doença, assim como sua severidade, são influenciadas pelo grau de desvio do ponto no qual, cada condição ambiental é ótima para o desenvolvimento da doença (Agrios, 1997).

Sentelhas (1992), estudando a ocorrência de helmintosporiose e de oídio na cultura do trigo sob diferentes condições microclimáticas, verificou que a maior densidade de plantio e o uso de irrigação por aspersão influenciaram a temperatura diminuindo-a, na media, em $0,7^{\circ} \mathrm{C}$, e aumentando a DPM em 48 minutos. No entanto, a densidade de plantio e a irrigação só apresentaram influência no desenvolvimento das doenças, quando as condições macroclimáticas não foram favoráveis ao desenvolvimento do patógeno. Isso também foi relatado por Rotem \& Palti (1969), que observaram uma redução de 8 a $9^{\circ} \mathrm{C}$ e aumento em $50 \%$ da umidade relativa quando se utilizou irrigação em condições extremas de altas temperaturas e baixa umidade. Já em baixa temperatura e alta umidade, a influência da irrigação foi desprezível.

A quantificação da influência das condições climáticas no desenvolvimento de epidemias é feita usualmente em experimentos conduzidos em câmaras de crescimento de plantas. Especial atenção tem sido dada à influência da temperatura, luz e umidade nos processos de infecção e colonização de patógenos foliares. Ensaios em câmaras de crescimento permitem isolar os efeitos de variáveis ambientais específicas, fornecendo dados que explicam o desenvolvimento epidêmico da doença em campo (Kranz \& Hau, 1980; Rotem, 1988). Desta forma, determinando-se o efeito do ambiente sobre o desenvolvimento dos processos de infecção e colonização de uma doença pode-se inferir sobre o desenvolvimento de epidemias no campo.

Embora a epidemiologia da ramulose tenha recebido alguma atenção no passado (Costa, 1941; Abrahão, 1961; Drummond, 1961; Tanaka, 1990; Teixeira, 1995; Santos, 1993; Cia, et al., 2001), a influência das condições ambientais no seu desenvolvimento ainda não foi totalmente esclarecida. 


\subsubsection{Temperatura}

A taxa de crescimento de um microorganismo - que é, certamente, a melhor integração da maioria de suas atividades metabólicas - varia conforme a temperatura. Essa relação entre crescimento e temperatura assemelha-se, dentro de um intervalo definido, à lei de Arrhenius, que descreve que a velocidade de uma reação química é função da temperatura, pois está relacionada com a energia de ativação necessária a cada processo. Isto está diretamente ligado com os processos biológicos de síntese e análise de um grande número de substâncias e moléculas essenciais, não só aos microorganismos, mas à vida em geral. No entanto, fora desse intervalo, próximo de um limite superior ou inferior, a curva de crescimento dos organismos vivos decresce abruptamente, até chegar a zero (Aragno, 1981).

$\mathrm{O}$ efeito da temperatura no desenvolvimento de microorganismos é muito estudado, tendo sido detectada sua influência em todas as fases do ciclo de infecção, desde a germinação dos esporos até a produção de novas unidades de reprodução. Sabese, mesmo sendo a temperatura um fator crítico para o desenvolvimento da cadeia de infecção, que temperaturas desfavoráveis para o desenvolvimento da doença no campo freqüentemente inibem uma epidemia temporariamente, mas não proporcionam a erradicação do patógeno (Rotem, 1978). Em condições de temperatura diferente do ótimo para o desenvolvimento do patógeno, a taxa de desenvolvimento da doença é reduzida, principalmente devido a um decréscimo no número de novas infecções e diminuição do inóculo, e o patógeno, que já se encontra no tecido infectado, continua seu desenvolvimento lentamente até que condições favoráveis de temperatura voltem a ocorrer (Rotem, 1978; Zadoks \& Schein, 1979).

De modo geral, o efeito da temperatura sobre a atividade do patógeno é menos marcante que aquele exercido pela umidade. A maioria dos patógenos, particularmente aqueles presentes em regiões tropicais e subtropicais, é capaz de crescer numa ampla faixa de temperatura. Portanto, nestas regiões, a temperatura não chega a atuar como fator limitante (Agrios, 1997), mas com certa ação depressiva, pois valores extremos afetam a evolução de doenças (Vale \& Zambolim, 1996), como verificado por 
Ortolani (1973), em estudos realizados com o fungo Hemilea vastatrix Berk et Br. em café no Estado de São Paulo, onde o autor cita que temperaturas elevadas, apresentam também, efeito indireto pois atuam como fator de evaporação, reduzindo a duração do molhamento foliar.

A temperatura está relacionada com a maior ou menor duração da etapa de germinação de esporos e, conseqüientemente, de infecção. A fase de penetração também pode ser influenciada pela temperatura. A temperatura exerce, ainda, influência nas etapas de colonização e reprodução. Em geral, para diversos patógenos, o período de tempo compreendido entre a inoculação e o aparecimento de esporos do patógeno diminui com o aumento de temperatura. No processo de reprodução, a temperatura pode afetar tanto a velocidade de produção de esporos, como a quantidade de propágulos formados (Bedendo, 1995).

A influência da temperatura na quantificação dos parâmetros monocíclicos de resistência como período latente, frequiência de infecção, período infeccioso e produção de esporos, tem sido estudada em diversos sistemas patógenohospedeiro, já que estes dados são de grande utilidade na construção de modelos de simulação de epidemias (Zadoks \& Schein, 1979). Observou-se que ao aumentar a temperatura de $10^{\circ} \mathrm{C}$ para $20^{\circ} \mathrm{C}$ ocorreu uma diminuição no valor do período latente de, aproximadamente dois dias para os patógenos Venturia inaequalis (Tormelin \& Jones, 1983); Alternaria helianthi (Allen et al., 1982); e Puccinia recondita tritici (Tormelin et al., 1983).

Tanaka (1995), relatam que o aumento da suscetibilidade das sementes em germinação e das plântulas aos patógenos está na dependência direta da temperatura. Baixas temperaturas podem aumentar a predisposição às doenças, através de um efeito estimulante da exsudação de substâncias orgânicas de sementes ou raízes que favorecem o crescimento e a infecção por microorganismos. Hayman (1969) verificou que durante a germinação de sementes de algodão, as mesmas exsudam mais carboidratos a $18^{\circ} \mathrm{C}$ do que a $24^{\circ} \mathrm{C}$ ou $30^{\circ} \mathrm{C}$. Por outro lado, temperaturas elevadas acima da ótima para germinação e o desenvolvimento da planta, podem aumentar as chances de infecção, desta vez através do mecanismo de supressão ou redução de fitoalexinas (Hunter \& 
Guinn, 1968; Hayman, 1969). No entanto, Krugner (1978) comenta que a temperatura ótima para a interação planta-patógeno poderá ser diferente daquelas ideais para o crescimento do patógeno ou da planta.

Santos (1993), estudando o progresso da ramulose do algodoeiro, verificou que o maior aumento da incidência foi verificado aos 81 dias, quando a umidade relativa e a temperatura mínima atingiram valores máximos de $90,2 \%$ e $18,3^{\circ} \mathrm{C}$, respectivamente. A falta de chuvas e o abaixamento da temperatura coincidiram com a paralisação da doença, demonstrando que essas variáveis climáticas são importantes para o progresso da doença.

\subsubsection{Duração do período de molhamento}

A água constitui-se num fator vital para a germinação de esporos e penetração no hospedeiro. Em particular, a água na forma de orvalho tem grande relevância no processo de infecção. Nesse caso, a intensidade da doença está diretamente relacionada à quantidade e a duração do período de orvalho. Embora uma grande parte dos patógenos fúngicos dependa do molhamento da superfície da planta para a germinação, alguns são desfavorecidos por esta condição, mas ainda assim, nestes casos, a germinação se dá com alta umidade do ar, próximo à saturação (Bedendo, 1995).

Vários autores evidenciam a importância do período de molhamento foliar, caracterizado quando a folha está coberta com uma película de água, proporcionada por orvalho, chuvas ou irrigação (Rotem, 1978; Pedro Júnior et al., 1991) para a ocorrência de epidemias em plantas, devido à formação de condições ideais para a germinação e penetração dos esporos. Assim, a presença ou ausência de água líquida nas superfícies da planta pode favorecer ou restringir o desenvolvimento da cadeia de infecção, principalmente nas fases de germinação e penetração (Zadoks \& Schein, 1979; Grove et al., 1985; Royle \& Butler, 1986).

Yarwood (1956) concluiu que os patógenos têm diferentes necessidades

de duração do período de molhamento (DPM) para o mesmo estágio de desenvolvimento da doença, de acordo com a temperatura, e o mesmo patógeno, requer 
períodos de umidade distintos nos diversos estágios de seu desenvolvimento.

Estudos sobre o número mínimo de horas de molhamento para a germinação de esporos de fungos fitopatogênicos na superfície foliar têm demonstrado que esse processo ocorre num espaço de tempo pequeno, onde um período de duas a cinco horas de molhamento foi suficiente para a germinação dos esporos de Puccinia coronata avenae (Politowski \& Browing ${ }^{3}$ ), Phyllosticta maydis (Castor ${ }^{4}$ et al.), Uromyces phaseoli (Imhoff $f^{5}$ et al.), Puccinia polysora (Hollier \& King $^{6}$ ) e Cercospora arachidicola (Alderman \& Beute ${ }^{7}$ ), todos citados por Mendes (1987). Mas a continuidade do processo de infecção, isto é, o crescimento do tubo germinativo, a formação do apressório e a infecção propriamente dita, requerem um maior número de horas de água livre na superfície foliar. Assim, no caso de Puccinia coronata avenae (Politowski \& Browing ${ }^{3}$ ), apesar da maioria dos uredosporos germinar em duas horas, a porcentagem de uredosporos com apressórios nesse período é bastante baixa e nenhuma infecção ocorre com menos de quatro horas de orvalho. Também no sistema Phyllosticta maydis - milho (Castor et al. ${ }^{4}$ ) a maioria dos uredosporos germina com 3,5 horas de orvalho mas um número significativo de infecções só foi obtido após um período de seis a nove horas de molhamento.

A duração do período de molhamento foliar necessário para ocorrência de infecção também é influenciada pela temperatura. Horsford et al. (1987), estudando a helmintosporiose do trigo nos E.U.A. verificaram que a infecção só ocorria com determinadas combinações de temperatura e molhamento. A uma temperatura de $10^{\circ} \mathrm{C}$ foram necessárias 12 horas de molhamento enquanto que a $20^{\circ} \mathrm{C}$ o molhamento necessário foi de 24 horas e a $30^{\circ} \mathrm{C}$ de 48 horas.

\footnotetext{
${ }^{3}$ POLITOWSKI, K.; BROWNING, J.A. Effect of temperature light and dew duration on relative numbers of infection structures of Puccinia coronata avenae. Phytopathology, v. 65, p. 1400-1404, 1975.

${ }^{4}$ CASTOR, L.L.; AYRES, J.E.; NELSON, R.R. Controlled environment studies of epidemiology of yellow leaf blight of corn. Phytopathology, v. 67, p. 85-90, 1977.

${ }^{5}$ IMHOFF, M.W.; LEONARD, K.J.; MAIN, C.E. Analysis of disease progress curves, gradients and incidence severity relationships for field and phytotron bean rust epidemics. Phytopathology, v. 72, p. 72-80, 1982.

${ }^{6}$ HOLLIER, C.A.; KING, S.B. Effect of dew period and temperature on infection of seedling maize plants by Puccinia polysora. Plant Disease, v. 69, p. 219-220, 1985.

7 ALDERMAN, S.C.; BEUTE, M.K. Influence, of temperature and moisture on germination and germ tube elongation of Cercospora arachidicola. Phytopathology, v. 76, p. 715-719, 1986.
} 
Essa relação temperatura-molhamento foliar também varia conforme o patógeno. Estudando a infecção de Microcylus ulei em seringueira, Gasparotto (1988) verificou ser necessário pelo menos 6 horas de molhamento a uma temperatura de $24^{\circ} \mathrm{C}$ para ocorrer infecção. A $20^{\circ} \mathrm{C}$ foram necessárias 8 horas de molhamento e a $16^{\circ} \mathrm{C}$ não houve infecção.

De maneira geral, sabe-se que são necessárias de duas a seis horas de molhamento para que ocorra um numero mínimo de infecções (Allen et al., 1983).

Estudos realizados em Israel onde o orvalho, completado com água de irrigação, é a principal forma de umidade na cultura, mostram que certos fungos fitopatogênicos, que normalmente necessitam de um longo período de orvalho para que ocorra a germinação dos conídios e infecção do hospedeiro, adaptaram-se às condições de poucas horas de orvalho da região, fazendo com que esporos que se encontram na fase de germinação resistam a um período seco e continuem a germinar no próximo período de molhamento. Porém, essa adaptação a períodos curtos de orvalho não é um fenômeno generalizado pois, Phytophthora infestans, por exemplo, não resiste a períodos secos após o início do processo de germinação, compensando esse fato pela alta taxa de germinação e penetração dos esporos (Bashi \& Rotem, 1974).

As chuvas têm importância elevada no processo de epidemias de plantas porque dispersam o inóculo, reduzem a luminosidade e provocam quedas de temperatura, aumentando a probabilidade de formação de orvalho por dias seguidos (Eversmeyer \& Burleigh, 1970).

\subsection{A ramulose}

Esta doença foi constatada pela primeira vez no município de Rancharia, SP, em 1936, e já se encontra disseminada praticamente por todas as regiões do país onde se cultiva o algodoeiro. Atualmente, vem causando problemas sérios nos Estados de Goiás, Mato Grosso do Sul, Mato Grosso e em algumas localidades do Nordeste brasileiro. Fora do Brasil, sua ocorrência é relatada somente na Venezuela e Paraguai. A doença é causada por uma variedade fisiológica do agente causal da antracnose e 
recebeu o nome de Colletotrichum gossypii South. var. cephalosporioides Costa. A principal via de disseminação do fungo é a semente, na qual pode ser veiculado externamente, na forma de conídios, ou internamente, na forma de micélio dormente. $\mathrm{O}$ fungo pode ainda sobreviver de um ano para outro em solo contaminado. Veiculado pela semente ou presente no solo, o inóculo primário causa lesões primárias em algumas plantas que vão servir como fonte de inóculo secundário. Lesões secundárias ocorrem nas plantas adjacentes, e o patógeno, propagando-se radialmente, forma reboleiras (Cia \& Salgado, 1995).

\subsubsection{Sintomatologia}

A ramulose pode manifestar-se em plantas de qualquer idade, desenvolvendo-se de preferência nos tecidos jovens. Os sintomas diretos aparecem primeiramente nas folhas novas, tanto na haste principal como nas laterais, na forma de manchas necróticas, mais ou menos circulares quando situadas no limbo entre as nervuras, e alongadas quando no sentido longitudinal. $\mathrm{O}$ tecido necrosado tende a cair, formando perfurações. As lesões, principalmente das nervuras, acarretam o desenvolvimento desigual dos tecidos foliares, ocasionando o enrugamento da superfície do limbo. O fungo afeta o meristema apical provocando sua necrose, o que estimula o desenvolvimento dos brotos laterais que se transformam em "ramos extranumerários", conferindo à planta um aspecto de superbrotamento ou envassouramento. Os internódios, por via de regra apresentam intumescimento. Plantas doentes ficam com porte reduzido (Paiva et al., 2001).

Quando a doença afeta plantas novas, as gemas terminais dos ramos extranumerários podem sofrer novas infecções e, pela sua morte, estimulam o desenvolvimento de novas gemas. Esse carrear de energias para o crescimento vegetativo em resposta a sucessiva destruição das gemas apicais, exaure completamente a planta para a finalidade de frutificação. Plantas doentes podem ser facilmente distinguidas das sadias pois estas derrubam as folhas e apresentam grande número de capulhos, ao passo que plantas doentes apresentam densa massa da folhagem escura e 
poucos capulhos. Normalmente, observam-se na parte inferior de plantas com muitos sintomas, algumas folhas mais desenvolvidas, de coloração verde mais escuro e aspecto coriáceo ou quebradiço (Cia \& Salgado, 1995).

A manifestação tardia da doença originou a denominação ramulose tardia, de sintomas muito semelhantes. Entretanto, plantas doentes apresentam o superbrotamento só no ápice, não afetando muito a produtividade (Abrahão, 1961; Cia \& Salgado, 1995).

\subsubsection{Disseminação e Epidemiologia}

As sementes de algodão têm um papel fundamental no estabelecimento da lavoura, além de ser o mais importante veículo de disseminação e sobrevivência de $C$. gossypii e C. gossypii var. cephalosporioides. Através das sementes esses microorganismos são introduzidos em novas áreas, sobrevivem através dos anos e se disseminam pela população de plantas, como focos primários de doenças (Goulart, 2001). Em condições normais de armazenamento, Kimati (1980) cita que o fungo pode permanecer viável no interior das sementes, como micélio dormente, por até três anos. Machado (1988) cita que o mesmo pode permanecer viável nestas condições por até cerca de 13 anos.

Sobre este aspecto é de capital importância que se conheça a taxa de transmissão de patógenos via sementes, estabelecendo a intensidade com que ela ocorre, apoiados em parâmetros como tipo, quantidade e posição do inóculo associados às

sementes no lote e, ainda, à extensão do processo de transferência deste inóculo às plantas emergente (Teixeira, 1995).

O conceito de transmissão em patologia de sementes implica na transferência do patógeno da planta-mãe para a semente ou da semente para a plântula (Tanaka, 1990; Machado, 1994). Em ambos os sentidos, a taxa de transmissão é bastante influenciada pelo ambiente e pelas características próprias do patógeno e do hospedeiro (Machado, 1994).

Tanaka (1990), estudando o agente causal da ramulose do algodoeiro, 
concluiu que nem sempre a resistência da planta adulta está relacionada com a resistência no estádio de plântula, com a percentagem do patógeno nas sementes, ou com a percentagem de transmissão semente-plântula.

Machado (1988) comenta que o conhecimento do estádio de desenvolvimento das plantas no qual a infecção se traduz em maior transmissão para as sementes, e destas para as plântulas, é um aspecto de grande valor em trabalhos de inspeção sanitária de campos. Com isto, é possível estimar em que época a incidência da doença na planta poderá significar maiores riscos de contaminação ou infecção das sementes. Por exemplo, Tanaka (1990), observou que a inoculação de Colletotrichum gossypii var. cephalosporioides, no estádio de maçãs formadas, comparada à inoculação 30 dias após a semeadura, resultou em maior associação do patógeno com as sementes produzidas. Assim, o tratamento químico de sementes com fungicidas, do ponto de vista

de manejo integrado de doenças, é um dos métodos mais simples, de baixo custo e resulta em reflexos altamente positivos para o aumento da produtividade da cultura (Goulart, 2001).

O grande desenvolvimento da epidemiologia nos últimos anos deveu-se, sem dúvida, às possibilidades de seu uso na otimização do controle de doenças. Hoje em dia, se aceita que para conseguir um controle econômico das doenças de plantas não é necessário bani-las de uma área e, desse modo, é função do epidemiologista encontrar um ponto de compromisso entre nível de doença e medidas de controle a serem utilizadas (Zadoks \& Schein, 1979).

Este ponto de compromisso, em essência, é a idéia que está por trás do manejo integrado de doenças e implica no conceito de que tanto a falta quanto o excesso de medidas de controle levam a prejuízos semelhantes (Lopes, 1994).

\subsubsection{Progresso da ramulose e Controle}

Entende-se como uma epidemia o crescimento de plantas doentes no tempo e no espaço (Zadoks \& Schein, 1979). A curva de progresso de doença mostra o desenvolvimento de uma epidemia num período de tempo, sob a influência de condições 
ambientais (Madden, 1980). Para Bergamin (1995), a curva de progresso da doença, usualmente expressa pela plotagem da proporção de doença versus tempo, é a melhor representação de uma epidemia. Através dela, interações entre patógeno, hospedeiro e ambiente podem ser caracterizadas, estratégias de controle avaliadas, níveis futuros de doença previstos e simuladores verificados.

Nos estudos envolvendo o progresso e o gradiente da ramulose no espaço, observa-se que a doença foi constatada nas plantas adjacentes à fonte de inóculo, aos 32 dias da emergência. A curva de progresso apresentou tendência linear até $2 \mathrm{~m}$ da fonte de inóculo. Nas áreas localizadas a partir de $3 \mathrm{~m}$ da fonte de inóculo, o aumento da incidência segue tendência sigmoidal (Santos, 1993).

$\mathrm{O}$ processo de infecção inicia-se quando a unidade de dispersão do patógeno entra em contato com o hospedeiro susceptível sob condições ambientais favoráveis (Zadoks \& Schein, 1979). O inóculo primário causa lesões primárias em algumas plantas que vão servir como fontes de inóculo secundário. As lesões secundárias ocorrem nas plantas adjacentes, e o patógeno, propagando-se radialmente, resulta em plantas com sintomas mais severos da ramulose, próximos dos focos iniciais (Kimati, 1980).

Abrahão (1961), em observações de campo, verificou que a disseminação da doença em condições normais, inicia-se a partir de reduzido número de plantas, às vezes, uma ou duas que funcionam como centro de irradiação. Há tendência de a ramulose disseminar-se em áreas circulares ou elípticas, mas também com aparecimento simultâneo de novos focos (Drummond, 1961).

A principal medida de controle é a utilização de cultivares com resistência ao patógeno. Outro método de controle é o uso de sementes sadias e seu tratamento com fungicidas eficientes. A Secretaria de Agricultura e Abastecimento do Estado de São Paulo adotou, a partir de 1949, a prática de não aproveitar sementes oriundas de campos de cooperação com sintomas severos de ramulose, aceitando uma tolerância de 5\% de plantas doentes. Complementarmente, recomendam-se a rotação de culturas e a queima dos restos de cultura (Cia \& Salgado, 1995).

Recomenda-se, ainda, o controle químico com fungicidas, os quais devem 
ser aplicados quando a doença se encontra na fase inicial de manchas necróticas. $\mathrm{O}$ controle químico não se mostra efetivo quando a doença encontra-se na fase de indução de superbrotamento. Rotação de cultura e destruição de restos culturais ajudam a manter a doença em níveis baixos de incidência (Paiva et al., 2001)

Nos estágios iniciais da ramulose tardia, recomendam-se ainda as seguintes medidas: 1) inspeção frequiente do campo para localização e erradicação das plantas foco; 2) poda e eliminação das extremidades das plantas doentes nas adjacências do foco; 3) pulverização preventiva com tiocarbamatos ou cúpricos das plantas sadias adjacentes às plantas erradicadas (Cia \& Salgado, 1995). 


\section{MATERIAL E MÉTODOS}

\subsection{Local}

O experimento foi conduzido na área experimental da Fazenda Areão do Campus "Luiz de Queiroz", Universidade de São Paulo (ESALQ-USP), no município de Piracicaba, Estado de São Paulo, localizado nas seguintes coordenadas geográficas: a) Latitude de $22^{\circ} 42^{\prime} \mathrm{S}$ e b) Longitude de $47^{\circ} 37^{\prime} \mathrm{W}$; a altitude é de 546 metros. A Tabela 1 apresenta os dados médios normais dos elementos meteorológicos no local de estudo.

Tabela 2. Dados médios mensais dos elementos meteorológicos em Piracicaba, SP. Período 1917 a 2000.

\begin{tabular}{|c|c|c|c|c|c|c|c|c|c|}
\hline Mês & 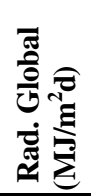 & 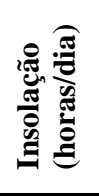 & 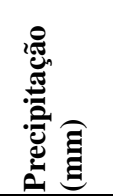 & 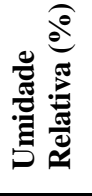 & 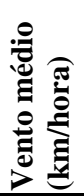 & 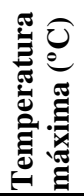 & 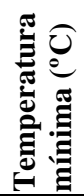 & 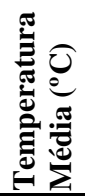 & 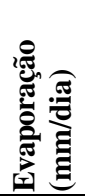 \\
\hline Jan & 18,8 & 6,4 & 224,5 & 76,3 & 7,8 & 30,0 & 19,0 & 24,4 & 4,5 \\
\hline Fev & 18,4 & 6,5 & 184,1 & 76,4 & 7,4 & 30,2 & 19,0 & 24,6 & 4,2 \\
\hline Mai & 16,7 & 6,8 & 143,2 & 76,1 & 7,2 & 30,0 & 18,2 & 24,1 & 4,0 \\
\hline Abr & 15,6 & 7,5 & 63,6 & 74,1 & 7,1 & 28,4 & 15,4 & 21,8 & 3,7 \\
\hline Maio & 12,6 & 7,3 & 52,1 & 75,2 & 6,4 & 26,1 & 12,1 & 19,1 & 3,1 \\
\hline Jun & 11,7 & 7,1 & 44,0 & 74,9 & 6,8 & 24,9 & 10,3 & 17,6 & 2,9 \\
\hline Jul & 12,8 & 7,8 & 27,2 & 69,9 & 7,5 & 25,3 & 9,5 & 17,4 & 3,5 \\
\hline Ago & 14,7 & 8,1 & 29,7 & 64,3 & 8,2 & 27,3 & 11,0 & 19,1 & 4,6 \\
\hline Set & 15,8 & 6,8 & 63,9 & 65,0 & 9,3 & 28,1 & 13,4 & 20,7 & 5,3 \\
\hline Out & 18,2 & 6,9 & 110,3 & 69,7 & 9,8 & 28,9 & 15,6 & 22,3 & 5,2 \\
\hline Nov & 19,8 & 7,4 & 130,4 & 69,8 & 9,7 & 29,6 & 16,7 & 23,1 & 5,5 \\
\hline Dez & 18,8 & 6,6 & 201 & 74,5 & 8,9 & 29,6 & 18,2 & 23,9 & 4,9 \\
\hline
\end{tabular}

Fonte: Departamento de Ciências Exatas/ESALQ/USP. 
O clima da região segundo a classificação de Köppen, é Cwa, tropical úmido com seca no inverno (Pereira et al., 2002).

\subsection{Cultura: Cultivares, Semeadura e Condução}

Foram utilizadas para o estudo duas cultivares de algodoeiro: IAC-23, resistente a ramulose, e COODETEC-401, suscetível à doença.

A cultivar IAC-23 foi desenvolvida pelo Instituto Agronômico de Campinas (IAC). Tem origem na linhagem IAC RR-97/86, obtida no projeto de melhoramento genético para resistência a ramulose, mediante resseleções sucessivas na cultivar IAC 20. Teve como principais objetivos a estabilidade de produção e resistência à doenças. Esta cultivar apresenta elevado desempenho agronômico com potencial produtivo médio de 187 @/ha e porcentagem de fibra de 40\% (Cia \& Fuzatto, 2002).

A cultivar COODETEC-401 foi desenvolvida pela COODETEC em parceria com a CIRAD. Foi obtida através de seleção genealógica de linhas segregantes de origem Argentina e Africana com objetivo de melhorar a qualidade e rendimento de fibra e adaptação. Esta cultivar apresenta elevado desempenho agronômico com potencial produtivo médio de 191 @/ha e porcentagem de fibra de 41,1\% (COODETEC, 1999).

As parcelas experimentais foram constituídas de quatro linhas de $5 \mathrm{~m}$ de comprimento, considerando-se úteis apenas as duas linhas centrais. $\mathrm{O}$ espaçamento utilizado entre linhas foi de $0,90 \mathrm{~m}$ em todas as parcelas. Uma das variáveis estudadas foi à densidade populacional da cultura. Sendo fixo o espaçamento entre linhas, foram definidos 3 espaçamentos entre plantas na linha de plantio. Assim, o espaçamento médio entre as plantas foi em torno de $20 \mathrm{~cm}$ nas parcelas menos densas, $10 \mathrm{~cm}$ nas intermediárias e $6,67 \mathrm{~cm}$ entre plantas nas parcelas mais densas. Tais espaçamentos corresponderam a 5, 10 e 15 plantas por metro ou, respectivamente, 55.555, 111.111 e 166.666 plantas por hectare. 
Em resumo, os tratamentos foram assim definidos:

T1 - Cultivar IAC 23, densidade de 05 plantas por metro;

T2 - Cultivar IAC 23, densidade de 10 plantas por metro;

T3 - Cultivar IAC 23, densidade de 15 plantas por metro;

T4 - Cultivar Coodetec 401, densidade de 05 plantas por metro;

T5 - Cultivar Coodetec 401, densidade de 10 plantas por metro;

T6 - Cultivar Coodetec 401, densidade de 15 plantas por metro.

Foram implantadas seis repetições de cada tratamento, inoculadas com a doença. No entanto, foram instalados também, tratamentos adicionais em parcelas que não receberam inoculação: seis repetições não inoculadas de T2 e T5, e duas repetições não inoculadas dos demais tratamentos (T1, T3, T4 e T6). Os tratamentos não inoculados foram utilizados com o objetivo de se estudar a ocorrência da ramulose em condições normais de disseminação, sem o processo artificial de inoculação. Os tratamentos não inoculados T2 e T5, também com 6 repetições, puderam ser analisados estatisticamente junto com os tratamentos inoculados, pois contavam com o mesmo número de repetições. Os demais tratamentos não inoculados, com apenas duas repetições, foram utilizados apenas para comparações não estatísticas (Tabela 3).

Tabela 3. Tratamentos e respectivos números de repetições utilizadas.

\begin{tabular}{ccc}
\hline Tratamento & Parcelas inoculadas & Parcelas não inoculadas \\
\hline T1 & 6 & 2 \\
T2 & 6 & 6 \\
T3 & 6 & 2 \\
T4 & 6 & 2 \\
T5 & 6 & 6 \\
T6 & 6 & 2 \\
\hline
\end{tabular}

O delineamento estatístico adotado foi o de parcelas simples inteiramente ao acaso. A Figura 1 apresenta uma ilustração esquemática da área do experimento. 


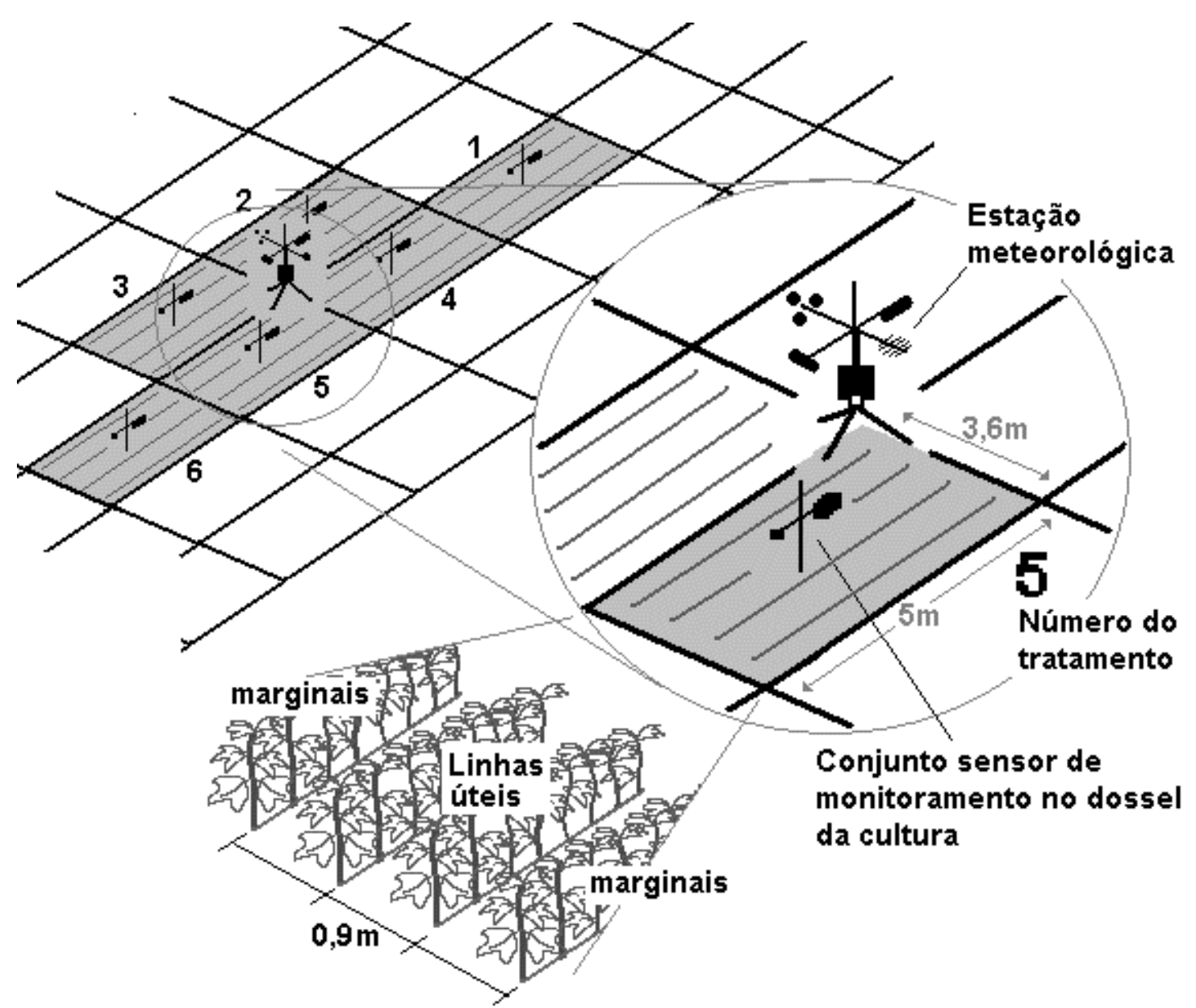

Figura 1 - Ilustração esquemática da área experimental, distribuição dos tratamentos e equipamentos de monitoramento agrometeorológico.

A semeadura foi realizada no dia 08 de novembro de 2001. Foi utilizado excesso de sementes e, em torno de 30 dias após a germinação, efetuou-se um desbaste para ajustar o número de plantas por metro em cada parcela de cada uma das densidades estabelecidas.

Os tratos culturais e a aplicação de defensivos, exceto fungicidas, foram semelhantes aos empregados em lavouras comerciais bem conduzidas. Não foi empregada irrigação em nenhuma fase do ensaio. 


\subsection{Inoculação e Avaliações da Doença}

Como na área experimental não havia histórico de ocorrência de ramulose, foi preciso garantir a presença do patógeno através da sua inoculação.

Os isolamentos de Colletotrichum gossypii var. cephalosporioides foram cedidos pelo Centro de Pesquisa e Desenvolvimento de Fitossanidade do Instituto Agronômico de Campinas. As culturas do fungo, foram desenvolvidas em meio sólido e, após o período de incubação, foi preparada a suspensão de esporos.

Para este processo, foi adicionado de 15 a $20 \mathrm{~mL}$ de água destilada em cada placa de Petri, contendo a cultura do fungo e, com auxílio de uma colher, foi removida a parte superficial da colônia, sem o agar. $\mathrm{O}$ material resultante foi misturado completando-se o volume a 2 litros de água destilada e, em seguida, filtrado em duas camadas de gaze esterilizada, obtendo-se assim, a suspensão de conídios, cuja concentração foi determinada com o auxílio do hemacitômetro.

Em seguida, a suspensão inóculo foi introduzida em um pulverizador costal e seu volume completado a 20 litros, capacidade total do pulverizador, resultando numa concentração aproximada de $10^{6}$ conídios por $\mathrm{mL}$.

A primeira inoculação foi feita no dia 19/12/2001, logo após o pôr do Sol, a fim de se favorecer o processo de infecção. A solução de inóculo foi pulverizada sobre todas as plantas de todas as parcelas, exceto nas parcelas definidas como testemunhas, que não foram inoculadas. Nesta data já havia sido feito o ajuste do número de plantas por metro através do desbaste, a cultura completava 31 dias após a emergência e encontrava-se no estádio fenológico R1 com o aparecimento do primeiro botão floral. A segunda inoculação foi realizada no dia 05/01/2002, ainda em R1, a fim de se reforçar a presença do inóculo, repetindo-se os mesmos procedimentos.

As avaliações dos sintomas da doença foram realizadas aproximadamente a cada 7 dias no intervalo entre a primeira e a segunda inoculação. Posteriormente, a cada 14 dias até o final do ciclo. Foram marcadas cinco plantas de cada uma das duas linhas centrais (úteis) e as notas correspondentes ao grau de severidade eram atribuídas sempre às mesmas plantas. A nota média da parcela foi dada pela média aritmética das 
notas das 10 plantas avaliadas.

A intensidade da doença foi estimada por meio de uma chave descritiva (Cia et al., 1982) considerando-se os seguintes graus:

Nota 1: ausência de sintomas;

Nota 2: apenas lesões necróticas nas folhas ou ramos;

Nota 3: comprometimento da região apical, morte do meristema;

Nota 4: superbrotamento da região apical;

Nota 5: superbrotamento da região apical e redução acentuada do porte da planta em relação às plantas sadias.

Alguns dos sintomas provocados pela ramulose, como as lesões necróticas "estreladas" no limbo foliar e o super-brotamento apical, podem ser visualizados na Figura 2.

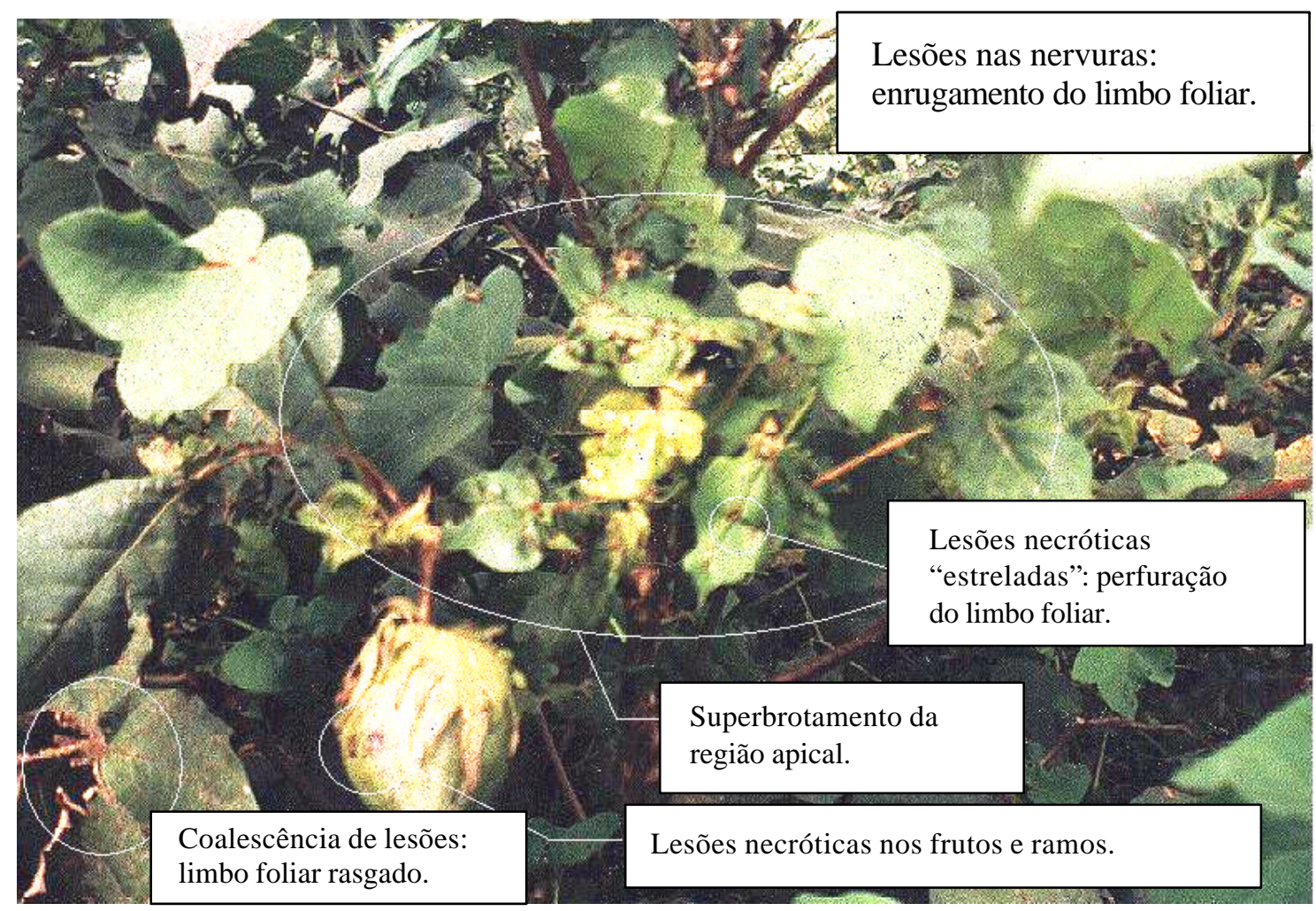

Figura 2 - Alguns sintomas da ramulose: lesões necróticas em forma de "estrela" com perfurações no limbo foliar e superbrotamento da região apical de um algodoeiro. 


\subsection{Avaliações Fitotécnicas}

\subsubsection{Fases fenológicas}

A Tabela 4 apresenta as fases fenológicas da cultura do algodoeiro e as épocas de ocorrência de cada fase.

Tabela 4. Fases fenológicas do algodoeiro e correspondente época de ocorrência (DAE).

\begin{tabular}{cccc}
\hline Fase fenológica & $\begin{array}{c}\text { Dias após } \\
\text { emergência }\end{array}$ & Fase fenológica & $\begin{array}{c}\text { Dias após } \\
\text { emergência }\end{array}$ \\
\hline Semeadura (8/nov) & - & R2 & 53 \\
VE (18/nov) & 0 & R3 & 57 \\
VC & 3 & R4 & 64 \\
V1 & 6 & R5 & 73 \\
V2 & 8 & R6 (CD 401) & 81 \\
V3 & 12 & R6 (IAC 23) & 84 \\
V4 & 15 & R7 (CD 401) & 111 \\
V5 & 19 & R7 (IAC 23) & 115 \\
V6 & 22 & Colheita inicial & 128 \\
V7 & 25 & R8 (CD 401) & 145 \\
VR & 27 & R8 (IAC 23) & 152 \\
R1 & 29 & Colheita final & 158 \\
\hline
\end{tabular}

\subsubsection{Desenvolvimento de um método de estimação da área foliar}

Para as determinações da área foliar das plantas ao longo do ciclo, foi desenvolvido um método baseado nas medidas do comprimento e largura da folha. O comprimento da folha foi definido como a distância entre o ponto de inserção do pecíolo no limbo foliar e a extremidade oposta da folha. E a largura, definida pela maior dimensão perpendicular ao eixo do comprimento, como mostra a Figura 3. 


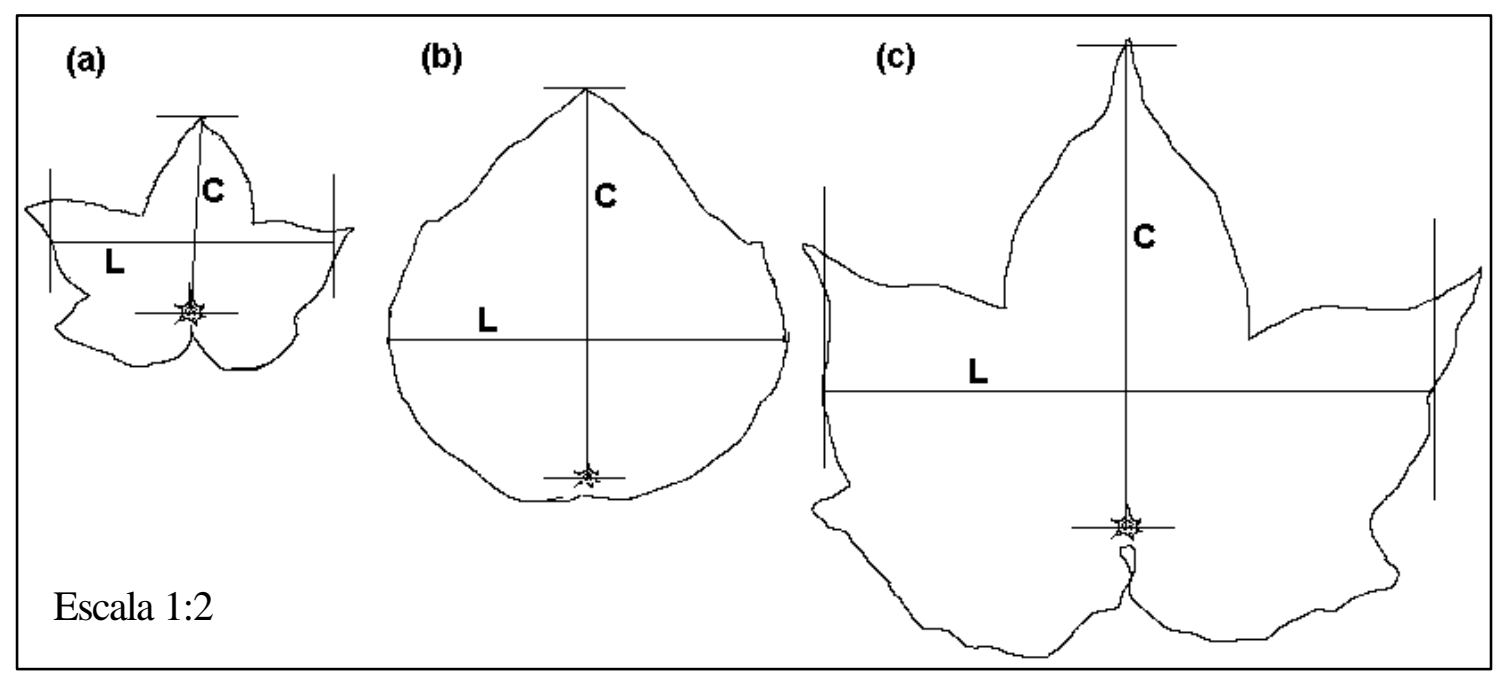

Figura 3 - Contorno de imagens digitalizadas de folha jovem em expansão (a), folha cordiforme (b) e folha lobada expandida (c), com as indicações de seus respectivos comprimentos e larguras.

A área das folhas (Af) foi então calculada como sendo o produto entre as duas dimensões - comprimento (C) e largura (L) - e um fator de forma " $\mathrm{f}$ ", como segue:

$$
A f=f^{*}\left(C^{*} L\right)
$$

Visualmente, pode-se distinguir com facilidade quanto à forma, três grupos distintos de folhas (Figura 3), podendo ser definidas diferentes classes. Foram definidas como pertencentes à classe 1 as folhas jovens, em expansão, que são bastante irregulares. As folhas da classe 2, as cordiformes, são bastante regulares mas tem importância apenas nas fases iniciais de desenvolvimento da planta. As folhas da classe 3 , denominadas de lobadas, são maiores e mais regulares que as folhas novas. Devido às características de formato de cada classe, foi determinado o fator "f" para cada uma das três classes.

$\mathrm{O}$ fator de forma " $\mathrm{f}$ " foi determinado através de análise de regressão simples entre a área de uma amostra de folhas e o produto de suas dimensões. A área foliar das folhas amostradas foram determinada através da digitalização das respectivas imagens e posterior cálculo da área com o software Embrapa SIARC 3.0, de análise de imagens. Em seguida, o fator de cada classe foliar foi testado e validado empregando-se 
a análise de regressão entre a área foliar estimada e a área foliar medida por meio de digitalização, em uma nova amostra de folhas, ou seja, dados independentes.

Conforme o grau de desenvolvimento da planta a proporção de cada classe de folha varia em relação o total. As proporções de cada classe de folhas foram, então, determinadas aos 32, 65 e 95 dias após emergência da cultura (DAE), de plantas obtidas na densidade populacional de 10 plantas por metro. O fator " $\mathrm{f}$ " foi ponderado, levando-se em consideração a proporção de cada classe nos momentos em que foram feitas as avaliações.

\subsubsection{Altura de plantas, Massa Seca e Área Foliar}

Aos 32, 65, 95 e 150 dias após a emergência das plântulas, foram avaliadas, aleatoriamente, duas plantas de cada parcela.

A altura das plantas foi determinada com trena métrica. Em seguida, estas foram cortadas rente ao solo e levadas ao laboratório onde as dimensões, comprimento e largura, de cada folha foram anotadas para a determinação da área foliar.

De posse da área foliar de cada planta e, na seqüência, da área foliar média de cada planta por tratamento, a determinação do índice de área foliar foi obtido pela multiplicação da área foliar média das plantas amostradas pelo número de plantas por metro quadrado, para cada densidade de plantio estudada.

Quando as plantas de algodoeiro atingiram a fase fenológica R8, mais ou menos aos 150 DAE, com cerca de $2 / 3$ de desfolha, foi realizada a última estimativa de área foliar. Nessa fase, a área foliar foi estimada como sendo $1 / 3$ da área foliar determinada aos 95 DAE, pelo método das dimensões. Esse valor foi útil apenas para efeitos ilustrativos, para traçar as curvas de índice de área foliar ao longo do ciclo da cultura até próximo ao fim do ciclo.

A partir das curvas de IAF, foram determinadas para cada tratamento, a duração da área foliar (DAF), que consistiu na integração da área foliar ao longo do tempo, ou seja, a área foliar de um determinado período multiplicada pelo número de dias do mesmo período. Por exemplo, a DAF entre 31 e 65 DAE foi determinada da 
seguinte forma:

$$
\operatorname{DAF}_{(31-65)}=\left[\left(\mathrm{IAF}_{31}+\mathrm{IAF}_{65}\right) / 2\right] *(65-31)
$$

Finalmente, todas as folhas, ramos e demais partes das plantas coletadas, foram levadas à estufa de secagem onde a fitomassa permaneceu, acondicionada em sacos de papel, durante 96 horas. Após este período cada planta foi pesada em balança eletrônica, com precisão $0,1 \mathrm{~g}$, para determinação da massa seca.

\subsection{4 Índice de Colheita e Produção}

$\mathrm{Na}$ avaliação de plantas aos 95 dias após emergência, quando as primeiras folhas das partes baixas começavam a apresentar senescência e queda, as maçãs foram acondicionadas e pesadas em sacos separados do restante da planta (partes vegetativas).

A determinação do índice de colheita (IC) foi feita pela razão entre a produção $(\mathrm{P})$ de algodão em caroço, obtida no final do ciclo, e a massa vegetativa seca (MS) medida aos 95 DAE, como segue:

$$
I C=P \div M S
$$

A produção dos tratamentos foi determinada, ao final do ciclo, através da colheita e pesagem da massa de algodão em caroço de todos capulhos das duas linhas centrais (úteis). Foram realizadas 4 colheitas, aos 128, 134, 143 e 158 dias após emergência (DAE). A produção de cada parcela foi colhida e ensacada individualmente. Nas colheitas dos dias 128 e 134 DAE, o algodão ainda não estava com umidade adequada para colheita. Foi retirada uma amostra de 20 capulhos por saco colhido, e determinada a umidade de cada uma para, depois, ser descontada do peso total colhido. 


\subsection{Instrumentação e Monitoramento Agrometeorológico}

\subsubsection{Estação Meteorológica}

Aos 30 dias após emergência das plântulas, após o ajuste de densidade por desbaste em cada tratamento, véspera da inoculação, foi instalado no centro da área experimental uma estação meteorológica padrão que forneceu os dados das condições meteorológicas durante o ciclo da cultura (Figura 1). Foi utilizado para leitura dos sensores um sistema automático (eletrônico) de aquisição de dados, marca Campbell Scientific, modelo CR23X. As variáveis monitoradas foram medidas a cada 10 segundos e armazenadas a cada 15 minutos pela média dos valores. A este sistema foram conectados os seguintes sensores e equipamentos:

1) Psicrômetro ${ }^{8}$ aspirado de termopar tipo $T$ (Cobre-Constantan), que forneceu os dados de temperatura de bulbo úmido e de bulbo seco, utilizados para a determinação da umidade relativa;

2) Sensor de radiação solar global, marca LI-COR, modelo LI-200SZ, de resposta espectral no intervalo entre 0,4 e $1,2 \mu \mathrm{m}$;

3) Sensor de radiação fotossinteticamente ativa, marca LI-COR, modelo LI190SZ, de resposta espectral no intervalo entre 0,4 a $0,7 \mu \mathrm{m}$;

4) Sensor de saldo de radiação ou saldo-radiômetro, marca Kipp \& Zonen, modelo NR-Lite, resposta espectral aproximada de 0,3 a $3 \mu \mathrm{m}$ e de 6 a $30 \mu \mathrm{m}$;

5) Sensor de molhamento foliar, marca Campbell Scientific, modelo 237;

6) Pluviômetro de báscula, marca Texas Eletronics, modelo TR-525M;

7) Anemômetro de caneca, marca Met-One, modelo 014A.

Além das variáveis monitoradas pela estação meteorológica na área experimental, foram utilizados, também, os dados registrados pela estação meteorológica automática do Posto Meteorológico do Departamento de Ciências Exatas, ESALQ/USP, situado a 5Km da área experimental e à mesma altitude.

\footnotetext{
${ }^{8}$ Psicrômetro aspirado construído pelo Departamento de Ciências Exatas, ESALQ/USP, conforme orientações obtidas em Marin et al. (2001).
} 


\subsubsection{Conjunto Sensor de Monitoramento Microclimático}

Junto com a estação meteorológica, aos 32 DAE (17/12/2001), foi instalado na parte central de cada parcela (Figura 4), um conjunto sensor com um psicrômetro aspirado de termopar e um sensor de molhamento foliar, especificados no subitem anterior, que forneceram os dados relativos à temperatura, umidade relativa e duração do período de molhamento foliar ao nível do dossel.

O conjunto sensor foi fixado na entrelinha das linhas centrais (úteis) de uma parcela de cada tratamento, perfazendo um total de seis conjuntos (um conjunto em cada um dos seis tratamentos inoculados). A altura dos sensores foi regulada de modo a acompanhar o crescimento da cultura, visando mantê-los sempre na mesma altura, ou seja, no terço superior das plantas (Figura 4).

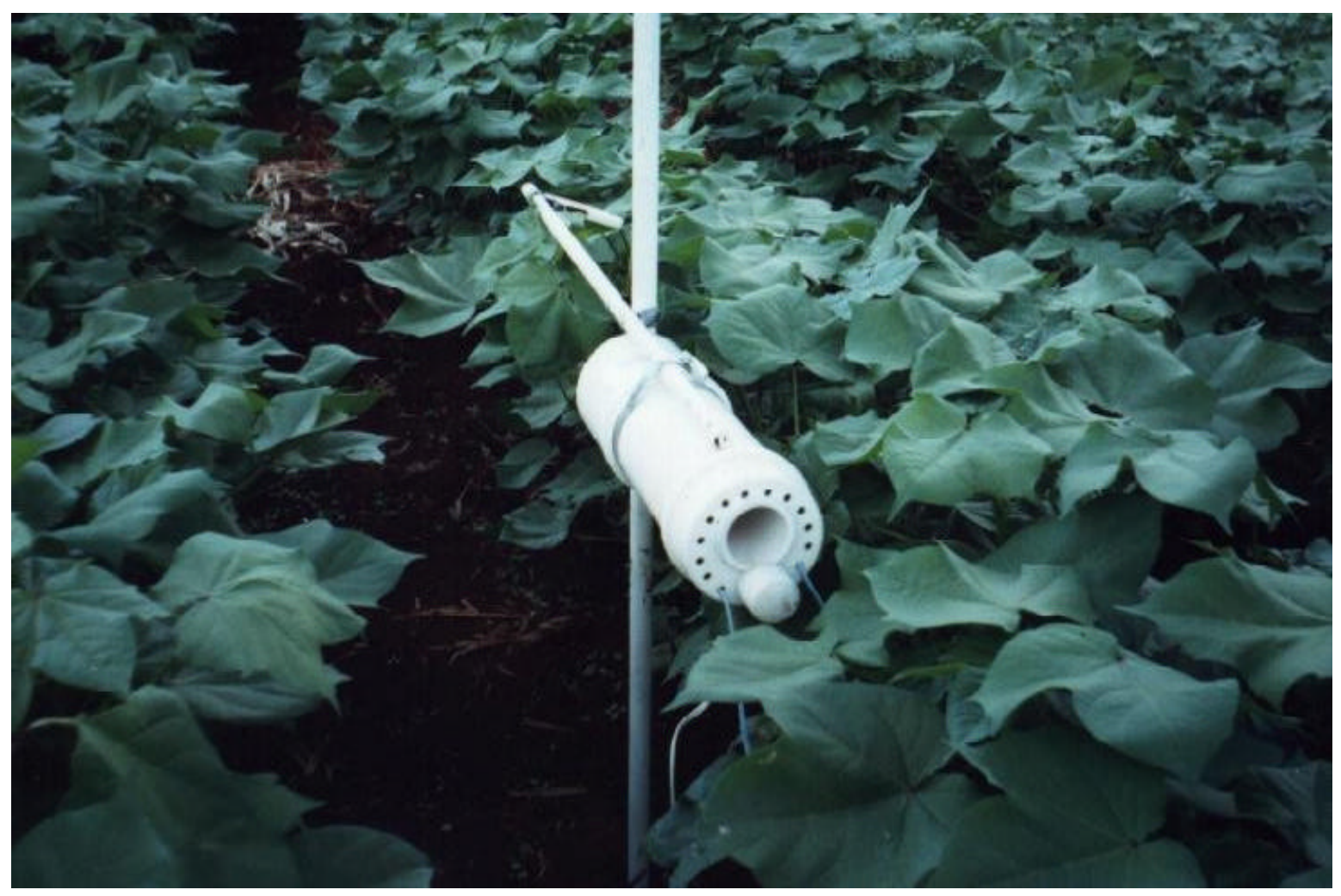

Figura 4 - Conjunto sensor de monitoramento meteorológico na altura do terço superior das plantas. 


\subsubsection{Avaliação dos sensores de molhamento foliar}

Os sensores de molhamento foliar, modelo 237, Campbell Scientific, que utilizam o princípio da variação da resistência elétrica conforme a presença ou ausência de água na sua superfície, foram fixados com uma inclinação de $20^{\circ}$ em relação ao plano horizontal, segundo recomendações de Gillespie \& Kidd (1978), a fim de se promover o escoamento do excesso de água depositado em sua superfície, como ocorreria naturalmente com as folhas do algodoeiro (Figura 5).

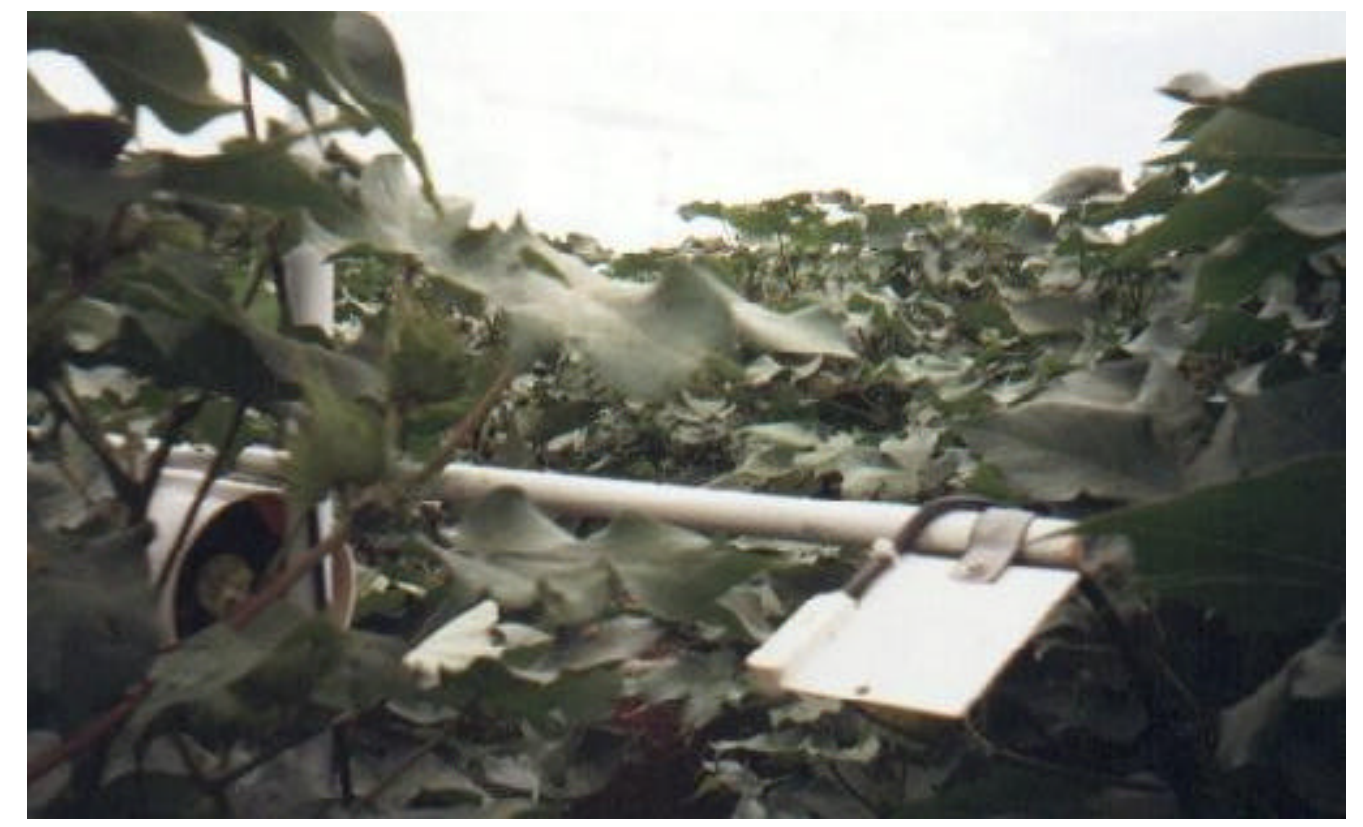

Figura 5 - Posicionamento do sensor eletrônico de molhamento foliar na altura do terço superior das plantas de algodoeiro.

Segundo o próprio fabricante, a resistência que define a transição entre seco e úmido nos sensores não pintados varia, normalmente entre 50 e 200 kohms. Logo, estes sensores apresentam inconsistências em suas medidas devido ao fato de que nem 
sempre a presença de gotículas de água em sua superfície são suficientes para causar mudança na sua resistência elétrica.

Assim, os sensores utilizados foram avaliados a fim de se verificar a confiabilidade dos mesmos. A obtenção dos dados de DPM para análise e comparações, foi dividida em dois períodos: 30 dias com os sensores sem pintura; e 30 dias com os sensores pintados com tinta látex branca.

Segundo Gillespie \& Kidd (1978) e Pedro Jr. ${ }^{9}$, a tinta látex seca sobre a superfície sensível do sensor, após ter sido submetida ao contato com vapor de água por 5 minutos, torna-se um bom absorvente de água liquida. Dessa forma, a tinta age absorvendo e dispersando as gotas de água em uma área maior da superfície do sensor, melhorando suas medidas.

Os resultados obtidos foram analisados mediante a comparação da DPM antes e após a pintura dos sensores e pela comparação entre a DPM medida e a estimada a partir do número de horas com a umidade relativa (NHUR) acima de $90 \%$.

\subsubsection{Coleta e Análise dos Dados}

A análise dos dados meteorológicos foi feita mediante a intercomparação dos dados microclimáticos - obtidos pelos sensores instalados junto ao dossel da cultura nos seis tratamentos inoculados - e, também, entre estes e as variáveis meteorológicas medidas na estação padrão, instalada na centro da área experimental.

A comparação entre tratamentos foi feita em momentos específicos do ciclo, ou seja, consistiram na média de sete dias subseqüentes as datas 30, 45, 60, 75, 90 , 105 e 120 dias após emergência (DAE). Aos 32, 65 e 95 DAE, foram feitas as avaliações de crescimento da cultura. Nessas épocas, as características das plantas de cada tratamento foram determinadas por meio das avaliações de área foliar, altura e massa seca; tais informações fornecem subsídios para análises e explicações da dinâmica dos respectivos microclimas.

Além disso, foram analisadas séries curtas de dados, de até sete dias

\footnotetext{
${ }^{9}$ PEDRO JR., M.J. Comunicação pessoal, 2001.
} 
consecutivos, a fim de se constatar a evolução do microclima da cultura ao bngo de uma sequiência continua, influenciada pelas variações nas condições do tempo, no transcorrer do ciclo, como por exemplo, a alternância de dias secos (desfavoráveis à doença) e chuvosos (favoráveis à doença).

Para a análise do crescimento das plantas de cada tratamento, além dos índices já mencionados - índice de área foliar, massa seca e altura das plantas - foi determinada a duração da área foliar (DAF).

A análise da doença foi feita empregando-se o grau de intensidade de cada tratamento, a incidência ao longo das avaliações, a taxa de crescimento da doença e, por fim, a área abaixo da curva de progresso da doença (AUDPC).

Quanto aos dados relativos à produção de algodão em caroço, foram determinados a produção total por unidade de área, o índice de colheita e a redução do rendimento provocado pela doença em relação às parcelas não inoculadas.

Por meio de análises de regressão linear simples foram determinados os possíveis graus de correlação entre os índices de crescimento da planta, de intensidade da doença e de produção.

As análises estatísticas foram feitas entre os dados das parcelas inoculadas das duas cultivares nas três densidades de plantio e, também, das parcelas não inoculadas somente na densidade 10 das duas cultivares, com igual número de repetições às inoculadas, ou seja, seis. Como os demais tratamentos não inoculados de 5 e 15 plantas por metro foram implantados com apenas duas repetições, a análise dos seus dados foi feita separadamente. 


\title{
4 RESULTADOS E DISCUSSÃO
}

\subsection{Análise de crescimento da cultura sadia}

\subsubsection{Massa seca e altura das plantas}

\begin{abstract}
A Figura 6 apresenta a variação da massa seca das plantas nas parcelas que não foram inoculadas com o fungo e, dessa forma, servem como base para a descrição do desenvolvimento da cultura sem a interferência da doença. As determinações foram feitas aos 32, 65, 95 e 150 dias após a emergência das plantas.

Como se observa, considerando-se as plantas individualmente, estas se desenvolveram mais quando conduzidas na densidade de 5 plantas por metro e menos na densidade de 15 plantas por metro (Figura 6b). No entanto, considerando-se o total de massa seca por área, a ordem é inversa, com maior quantidade de massa vegetal na maior densidade populacional, e menos massa seca nas parcelas de menor densidade (Figura 6a).

Isto evidencia uma elevada plasticidade fenotípica do algodoeiro, concordando com Amorim Neto e Beltrão (1999), e Beltrão e Souza (2001). Esta plasticidade permite que a planta se ajuste aos mais diversos ambientes, cuja variável, neste caso, foi à densidade populacional.
\end{abstract}


(a)
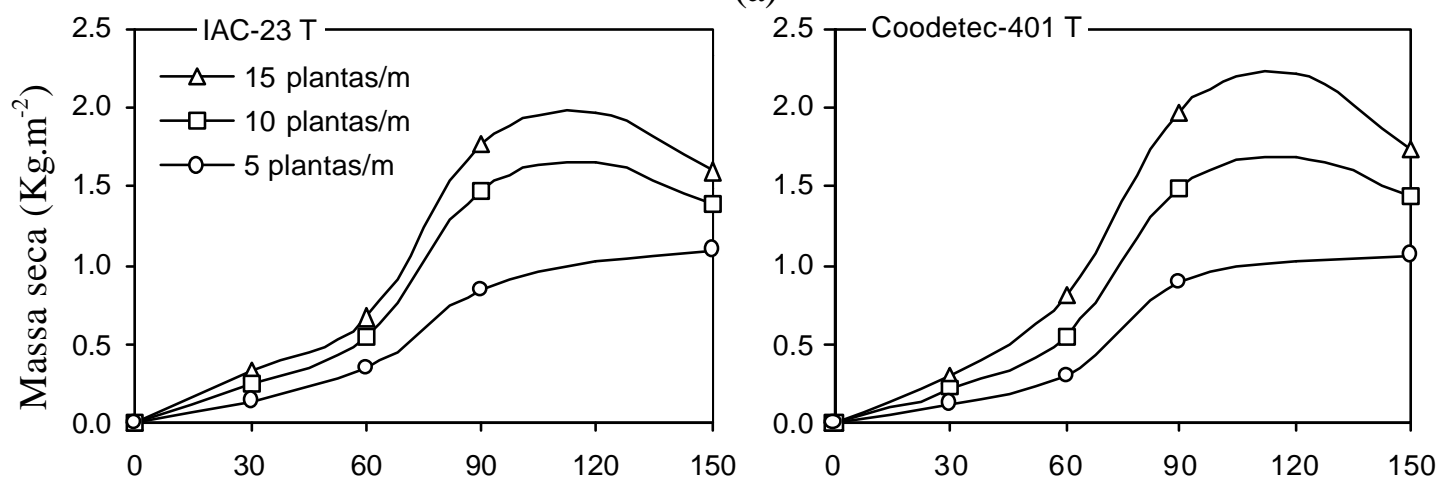

(b)
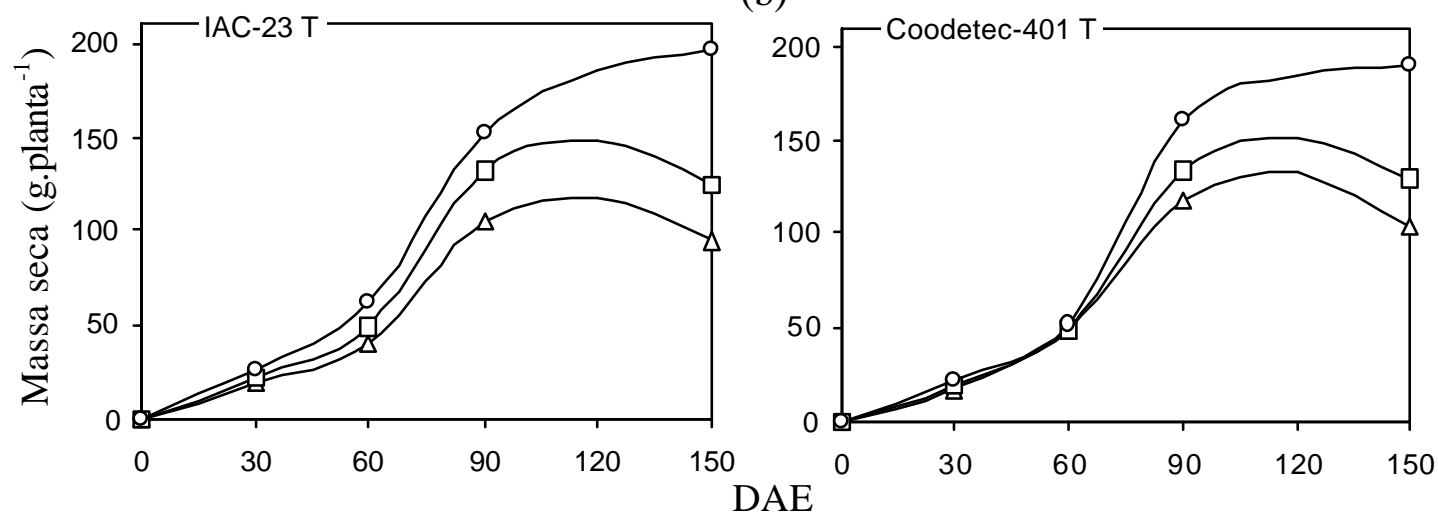

Figura 6 - Acúmulo de massa seca pelas cultivares de algodoeiro IAC 23 e Coodetec 401, testemunhas (T) - não inoculadas; de 0 a 150 dias após emergência (DAE), nas densidades de 5, 10 e 15 plantas por metro.

Embora este fenômeno seja bastante conhecido como uma característica do algodoeiro, a avaliação do desenvolvimento da cultura, por meio da massa seca, da altura e do índice de área foliar, foi fundamental para o entendimento do microclima em cada tratamento.

Apesar de terem sido verificadas diferenças significativas quanto ao acúmulo de massa seca pelas plantas entre os tratamentos, praticamente não houve diferença quanto à altura média das plantas entre as densidades populacionais adotadas. Constatou-se apenas uma ligeira diferença entre as cultivares, sendo que a cultivar Coodetec 401 apresentou altura média de 1,10m enquanto que na IAC 23, a altura média foi de 1,18m (Figura 7). No entanto, Belletini (1988), verificou diferença significativa, 
com maior a altura das plantas de algodoeiro cultivar IAC 20 na densidade de 5 plantas por metro do que na densidade de 10 plantas por metro, independente do espaçamento.
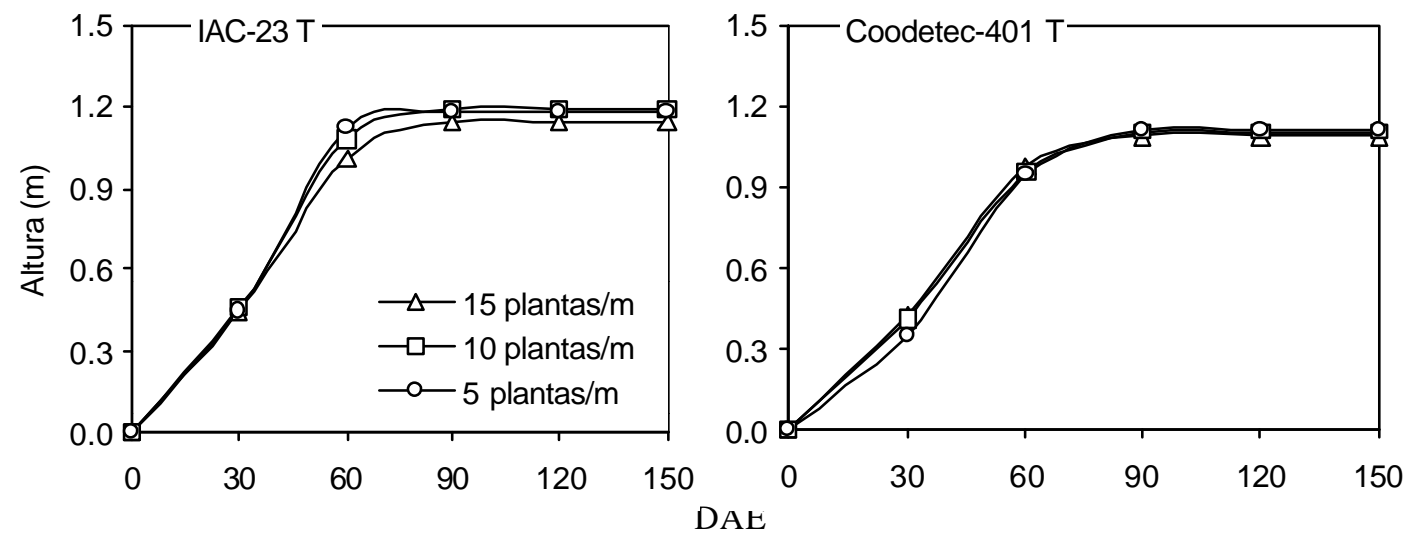

Figura 7 - Altura média das plantas das cultivares de algodoeiro IAC 23 e Coodetec 401, testemunhas (T) - não inoculadas; de 0 a 150 dias após emergência (DAE), nas densidades de 5, 10 e 15 plantas por metro.

\subsection{2 Área foliar}

\subsubsection{Desenvolvimento de um método de estimação da área foliar}

Como descrito em Material e Métodos, este método baseia-se nas dimensões das folhas - comprimento e largura - e foi utilizado para a estimação da área foliar das plantas de algodoeiro nos diferentes tratamentos ao longo do ciclo.

A primeira etapa, que consistia na determinação do fator de forma "f" para cada classe de folhas, por meio de análises de regressão com amostras de folhas, resultou nos coeficientes apresentados na Tabela 5.

A reta ajustada ao conjunto de dados possui uma equação do tipo:

$$
Y=b x
$$

em que "b" corresponde ao fator "f", determinado para as três classes foliares. Como pode ser observado na Tabela 5 , todas as análises foram estatisticamente significativas, pelo teste $\mathrm{F}$, para á = 0,05, e apresentaram elevados coeficientes de correlação $\left(\mathrm{R}^{2}\right)$. 
Tabela 5. Resultados da análise de regressão entre o produto do comprimento pela largura $\left(\mathrm{C}^{*} \mathrm{~L}\right)$ das folhas e a área foliar medida, classificadas em três tipos de folhas do algodoeiro.

\begin{tabular}{lccccccc}
\hline Cultivar & \multicolumn{3}{c}{ Coodetec 401 } & \multicolumn{3}{c}{ IAC 23 } \\
Parâmetros da análise & b & $\mathbf{R}^{2}$ & F & B & $\mathbf{R}^{2}$ & F \\
\hline Folhas novas $\left(<45 \mathrm{~cm}^{2}\right)$ & 0,7695 & 0,810 & $*$ & 0,7790 & 0,813 & $*$ \\
Folhas cordiformes & 0,8173 & 0,957 & $*$ & 0,8221 & 0,948 & $*$ \\
Folhas lobadas $\left(>45 \mathrm{~cm}^{2}\right)$ & 0,838 & 0,933 & $*$ & 0,8615 & 0,921 & $*$ \\
\hline
\end{tabular}

* Teste $\mathrm{F}$ significativo para á $=0,05$.

Na sequiência, a Figura 8 apresenta as análises de regressão entre a área foliar medida em uma amostra independente de folhas e a estimada a partir dos parâmetros apresentados na Tabela 5. Novamente, todas as análises foram significativas, pelo teste $\mathrm{F}$, para á = 0,05, e também com bons coeficientes de correlação.
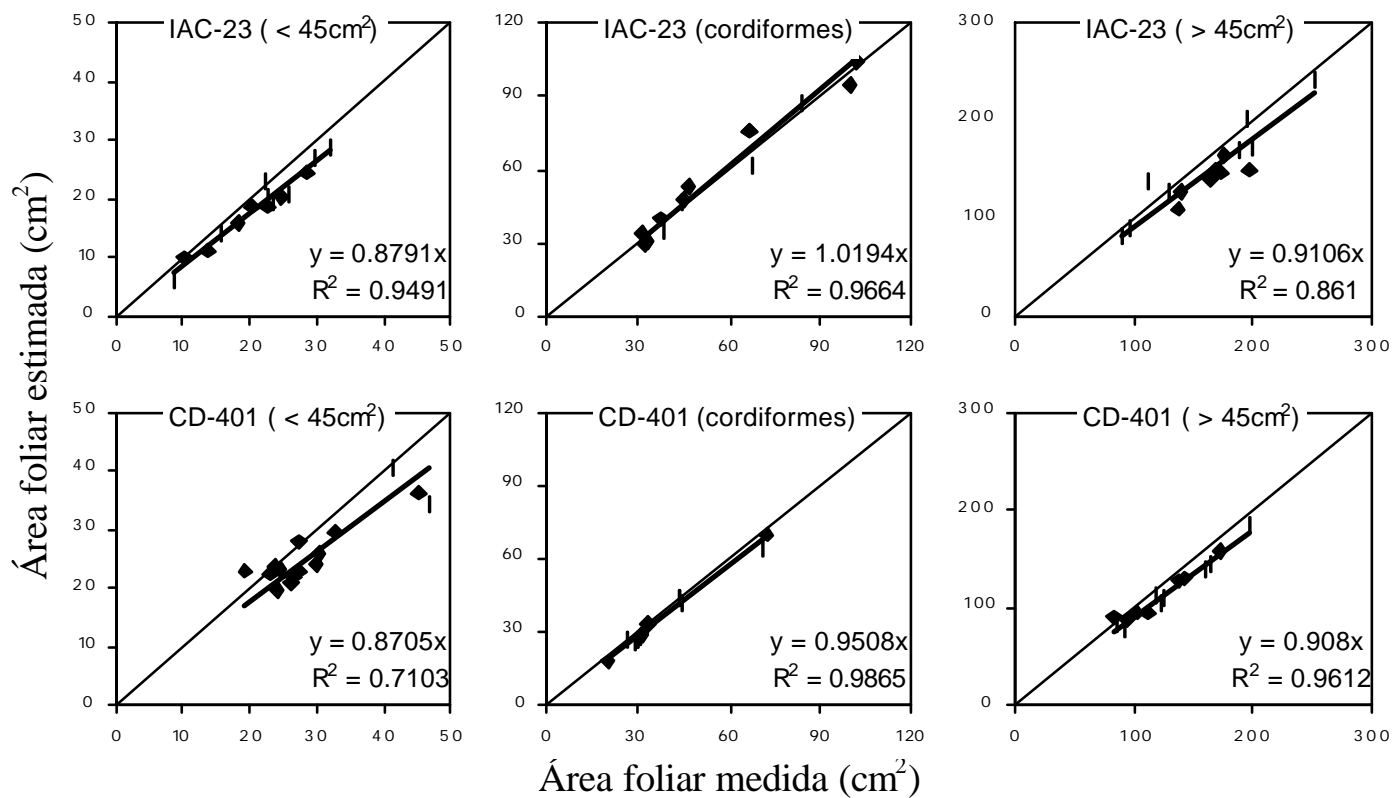

Figura 8 - Relação entre os valores de área foliar do algodoeiro, estimados pelas dimensões das folhas e os valores de área foliar medidos, nas três classes de folhas avaliadas, para o algodoeiro. 
As proporções de cada classe de folha, conforme a cultivar e o grau de desenvolvimento das plantas são apresentados na Tabela 6.

Tabela 6. Ponderação do número de folhas agrupadas ms três classes definidas, em três momentos do ciclo da cultura do algodoeiro: 32, 65 e 95 dias após emergência.

\begin{tabular}{lcccccc}
\hline Cultivar & \multicolumn{3}{c}{ Coodetec 401 } & \multicolumn{3}{c}{ IAC 23 } \\
Dias após emergência & 32 & 65 & 95 & 32 & 65 & 95 \\
\hline Total de folhas em 12 plantas & 158 & 627 & 832 & 160 & 464 & 673 \\
Percentual de folhas novas $\left(<45 \mathrm{~cm}^{2}\right)$ & 44,9 & 27,4 & 30,6 & 35 & 23,3 & 21,8 \\
Percentual de folhas cordiformes & 22,8 & 5,7 & 0,0 & 22,5 & 7,8 & 0,0 \\
Percentual de folhas lobadas $\left(>45 \mathrm{~cm}^{2}\right)$ & 32,3 & 66,8 & 69,3 & 42,5 & 68,9 & 78,2 \\
\hline
\end{tabular}

Como apresentado na Tabela 6 cada classe foliar apresentou um fator de forma característico. Foi, então, determinado um fator "f" único, para cada momento de avaliação, ponderando-se as proporções de cada classe. Os resultados dessa ponderação são apresentados na Tabela 7.

Tabela 7. Análise de regressão entre o produto do comprimento pela largura $(\mathrm{C} * \mathrm{~L})$ das folhas e a área foliar medida, ponderando-se as classes de folhas aos 32, 65 e 95 dias após emergência.

\begin{tabular}{lccccccc}
\hline Cultivar & \multicolumn{3}{c}{ Coodetec 401 } & \multicolumn{3}{c}{ IAC 23 } \\
Parâmetros da análise & $\mathrm{b}$ & $\mathrm{R}^{2}$ & $\mathrm{~F}$ & $\mathrm{~b}$ & $\mathrm{R}^{2}$ & $\mathrm{~F}$ \\
\hline 32 dias após emergência & 0,8054 & 0,975 & $*$ & 0,8389 & 0,954 & $*$ \\
65 dias após emergência & 0,8301 & 0,976 & $*$ & 0,8401 & 0,954 & $*$ \\
95 dias após emergência & 0,8334 & 0,975 & $*$ & 0,8601 & 0,947 & $*$ \\
\hline
\end{tabular}

* Teste F significativo para á $=0,05$. 
Como pode ser observado na Tabela 7, o fator de forma não variou muito conforme o momento considerado. No entanto, constatou-se claramente que o coeficiente de determinação aumentou, ou seja, a dispersão do conjunto de dados foi menor e, conseqüientemente, a precisão da estimativa foi maior.

A validação dos resultados, por meio de novas análises com dados independentes, confirma que dessa maneira, a precisão das estimativas é maior do que simplesmente utilizar um "f" para cada tipo de folha. Além disso, na prática, isso dificultaria muito o trabalho de determinação de área foliar pois exigiria que, além da medida das folhas, estas fossem separadas em classes. Na verdade, como foi demonstrado, é possível a utilização de um fator único, para cada fase do ciclo, para todas as folhas da planta, sem que haja prejuízo para a precisão da estimativa.

A Figura 9 apresenta a relação entre a área foliar estimada e medida (dados independentes), o que resultou em elevados coeficientes de determinação $\left(\mathrm{R}^{2}>0,96\right)$.
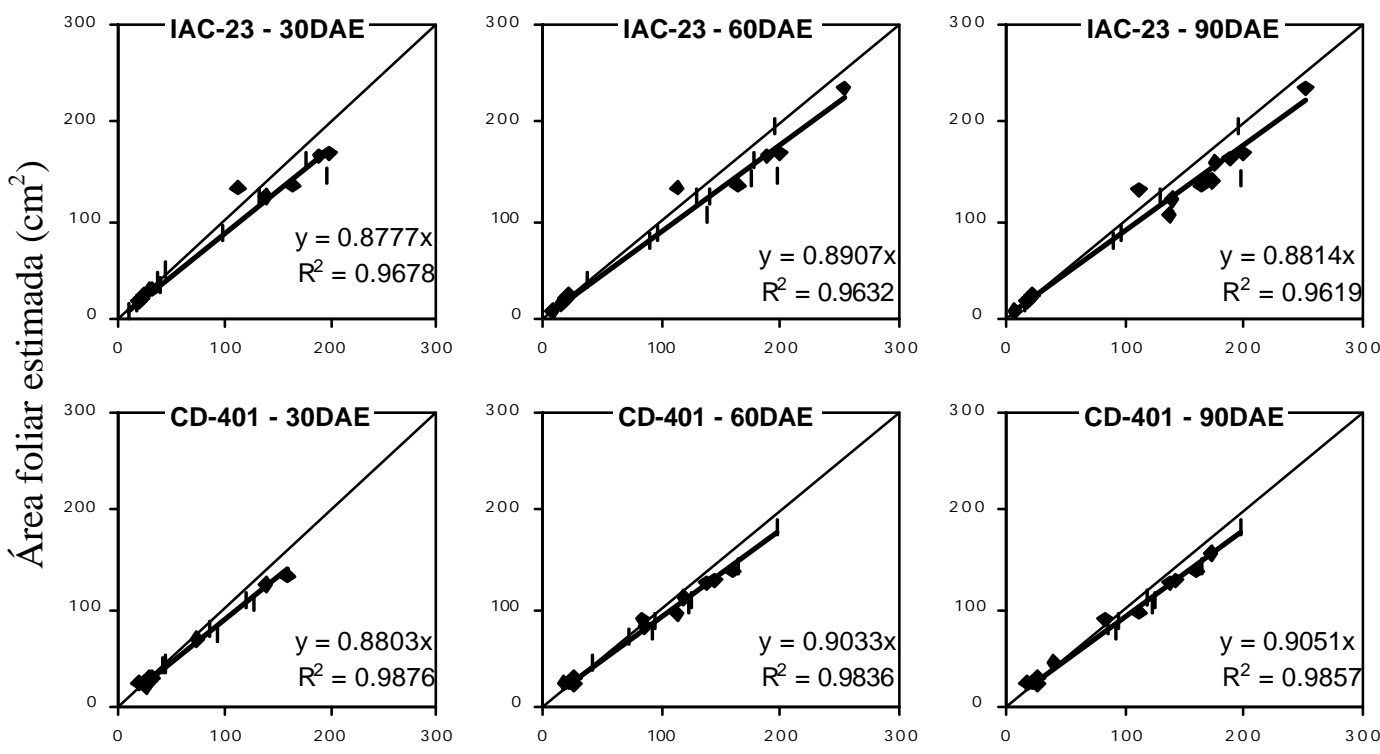

Área foliar medida $\left(\mathrm{cm}^{2}\right)$

Figura 9 - Relação entre os valores de área foliar do algodoeiro, estimados pelas dimensões das folhas e os valores de área foliar medidos, nas três épocas avaliadas. 
Uma vez verificada a precisão das estimativas obtidas com este método, foi feita, então, a estimação da área foliar da cultura, em cada tratamento.

\subsubsection{2 Índice de área foliar da cultura ao longo do ciclo}

A Figura 10 apresenta a variação do índice de área foliar (IAF) nas parcelas não inoculadas pelo patógeno. Na cultivar IAC 23, os gradientes de índice de área foliar - representados pela diferença entre o IAF medido nas densidades 15 e 10 plantas por metro e, as densidades de 10 e 5 plantas por metro - mantiveram-se proporcionais ao longo do ciclo. Por autro lado, na cultivar Coodetec 401, os gradientes não foram exatamente proporcionais em todos os momentos analisados. Na comparação entre as densidades de 5 e 10 plantas por metro, existiu um grande incremento m IAF da menor para a maior densidade, enquanto que, na comparação entre as densidades de 10 e 15 plantas por metro, o incremento de IAF foi muito menor. Ao que parece, a cultivar IAC 23 possui uma maior plasticidade fenotípica, o que significa uma maior capacidade de adaptação ao meio, neste caso, diferenciado pelas condições impostas por distintas densidades populacionais.
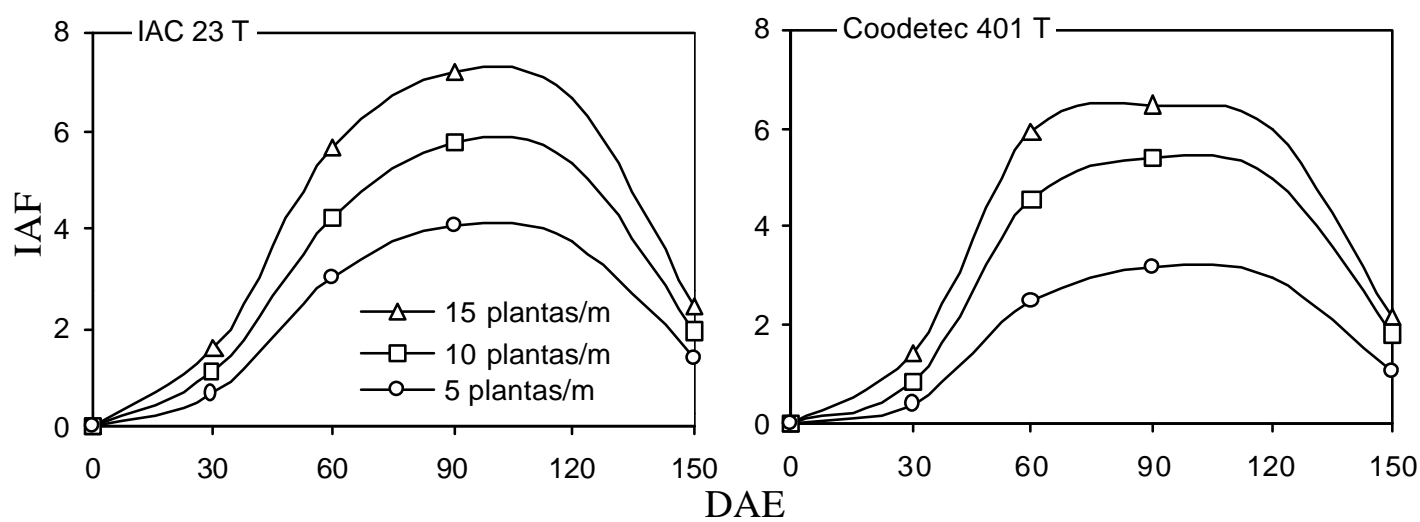

Figura 10 - Índice de área foliar das cultivares de algodoeiro IAC 23 e Coodetec 401, testemunhas (T) - não inoculadas; de 0 a 150 dias após emergência (DAE), nas densidades de 5, 10 e 15 plantas por metro. 
A variação do IAF entre os tratamentos ao longo do ciclo são determinantes do microclima da cultura.

É interessante identificar que na cultivar IAC 23 o IAF na densidade de 5 plantas por metro atingiu o valor máximo igual a 4,1, por volta de 90 a 100 DAE. O IAF nas densidades 10 e 15 plantas por metro, atingiram seus valores máximos, de 5,8 e 7,2, respectivamente, na mesma época. Na cultivar Coodetec 401, densidade de 5 plantas por metro, o valor máximo de 3,2 também foi atingido por volta de 90 a 100 DAE, enquanto que na densidade de 10 plantas por metro, o patamar máximo de 5,4 foi atingido por volta de 80 DAE e, finalmente, na densidade de 15 plantas por metro, o IAF máximo de 6,5, ocorreu aos 70 DAE.

\subsection{Microclima da cultura do algodoeiro}

A atmosfera interage com a vegetação ou superfície com que está em contato de acordo com suas características. Essas interações resultam em fluxos, trocas gasosas e de calor entre a superfície e o ar, que mudam as propriedades físicas da atmosfera adjacente, e definem as condições de microclima. Tais propriedades podem ser medidas e monitoradas através de instrumentos e sensores específicos. No entanto, dado que o microclima de uma cultura é a resultante da interação de diversos fatores, tanto da cultura como meteorológicos, este se torna bastante variável, tanto no tempo como no espaço.

De modo geral, os microclimas de cada densidade diferiram da condição geral do tempo - representada pelos dados registrados na estação meteorológica padrão e no Posto Meteorológico - com diferentes graus, de acordo com a fase do ciclo da cultura. Além disso, a fase da cultura afetou, principalmente, os gradientes entre as três densidades estudadas, sendo mais ou menos afetada, de acordo com a variável considerada. 


\subsubsection{Temperatura do ar}

A Figura 11 ilustra a variação da temperatura do ar ao longo do ciclo da cultura, no intervalo de 0 a 120 DAE, monitorada em três condições distintas: nas parcelas da cultura em três densidades populacionais, na estação meteorológica padrão na área experimental e no Posto Meteorológico da ESALQ/USP.

As medidas do conjunto sensor junto ao dossel da cultura são influenciadas diretamente pelas plantas de cada parcela. Já, as medidas na estação meteorológica representam a condição média da área experimental que também é influenciada pela cultura e, conseqüentemente, pelo grau de desenvolvimento da mesma. Logo, a evolução da temperatura registrada no mesmo período no Posto Meteorológico é útil como termo de comparação com as temperaturas registradas no experimento, já que, neste caso, as condições da superfície, ou seja, da cobertura vegetal, no Posto Meteorológico, são mantidas sempre as mesmas, e as variações de temperatura do ar se devem, principalmente, às condições do tempo.

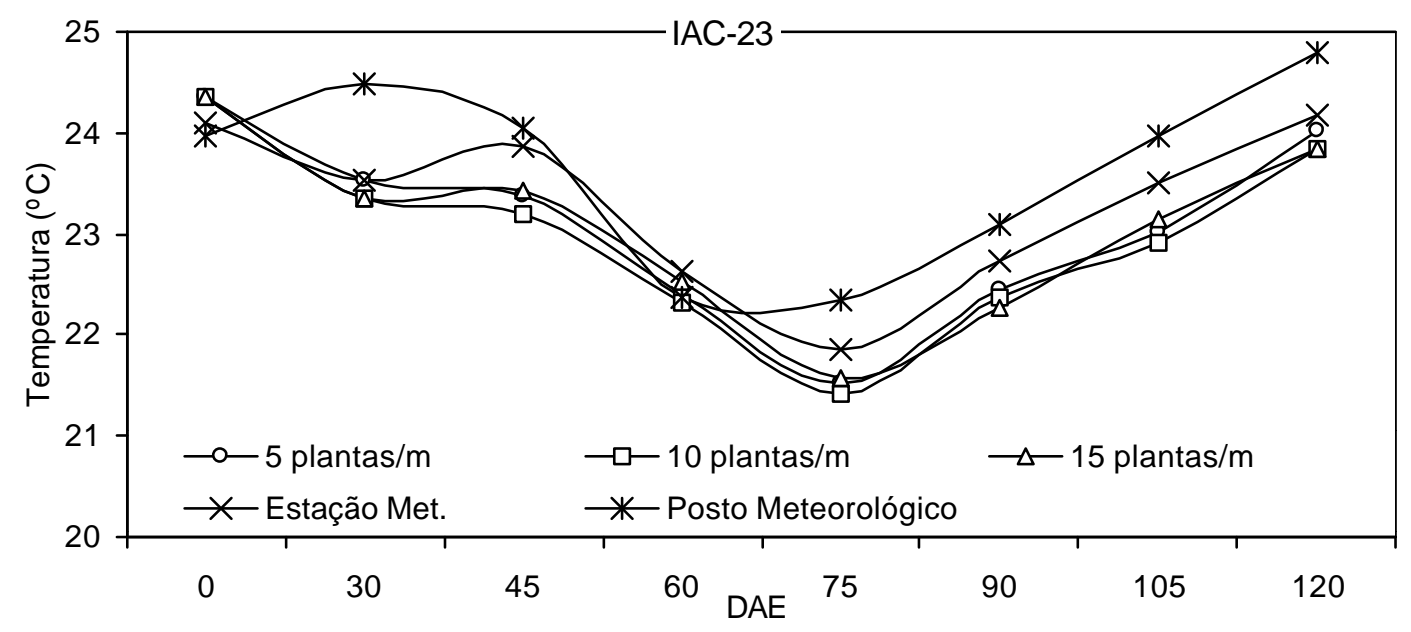

Figura 11 - Temperatura média do ar ao longo do ciclo da cultura do algodoeiro, medidas em cada densidade de plantio, na estação meteorológica da área experimental e no posto meteorológico (LCE/ESALQ/USP). 
No transcorrer do ciclo da cultura, é possível verificar que as maiores variações na temperatura média do ar ocorreram devido às condições do tempo. $\mathrm{Na}$ maior parte do período, as curvas são similares, de modo que a variação observada na área experimental acompanhou a verificada do Posto Meteorológico.

De fato, as curvas foram similares na maior parte do tempo, quase sempre paralelas. Em média, a diferença não passou de $0,5^{\circ} \mathrm{C}$ entre o Posto Meteorológico e a área experimental, de $0,4^{\circ} \mathrm{C}$ entre a estação meteorológica e as parcelas da cultura. $\mathrm{Na}$ comparação da temperatura média ao longo do ciclo entre as densidades de plantio, também não se encontrou diferença significativa. Sentelhas (1992) identificou influência da densidade populacional na temperatura do dossel da cultura do trigo, onde esta foi, em média, $0,7^{\circ} \mathrm{C}$ maior nas áreas menos densas. Porém, no ano seguinte e com irrigação, a diferença média foi de apenas $0,15^{\circ} \mathrm{C}$, atribuindo a isso, o fator termoregulador da água.

De maneira geral, espera-se ocorrer menor temperatura onde houver maior densidade de fitomassa pois, associa-se a isso, maior índice de área foliar, logo, maior evapotranspiração. Isso significa que, para as comparações da temperatura em culturas com diferentes densidades de fitomassa, é preciso considerar também, como a disponibilidade hídrica afeta o sistema.

A comparação feita em momentos específicos como, por exemplo, em dias de pouco vento, revela aspectos interessantes do microclima, como apresentado na Figura 12, que apresenta a variação da temperatura do ar medida na estação meteorológica padrão, no centro da área experimental, e da temperatura medida junto à cultura, no dia 02 de janeiro de 2002. Os valores de temperatura chegaram a uma diferença de até $4,6^{\circ} \mathrm{C}$ por volta das 20 horas, ou seja, enquanto o sensor da estação media uma temperatura de $27,6^{\circ} \mathrm{C}$ nesse horário, no terço superior da cultura os sensores indicavam em torno de $23^{\circ} \mathrm{C}$. 


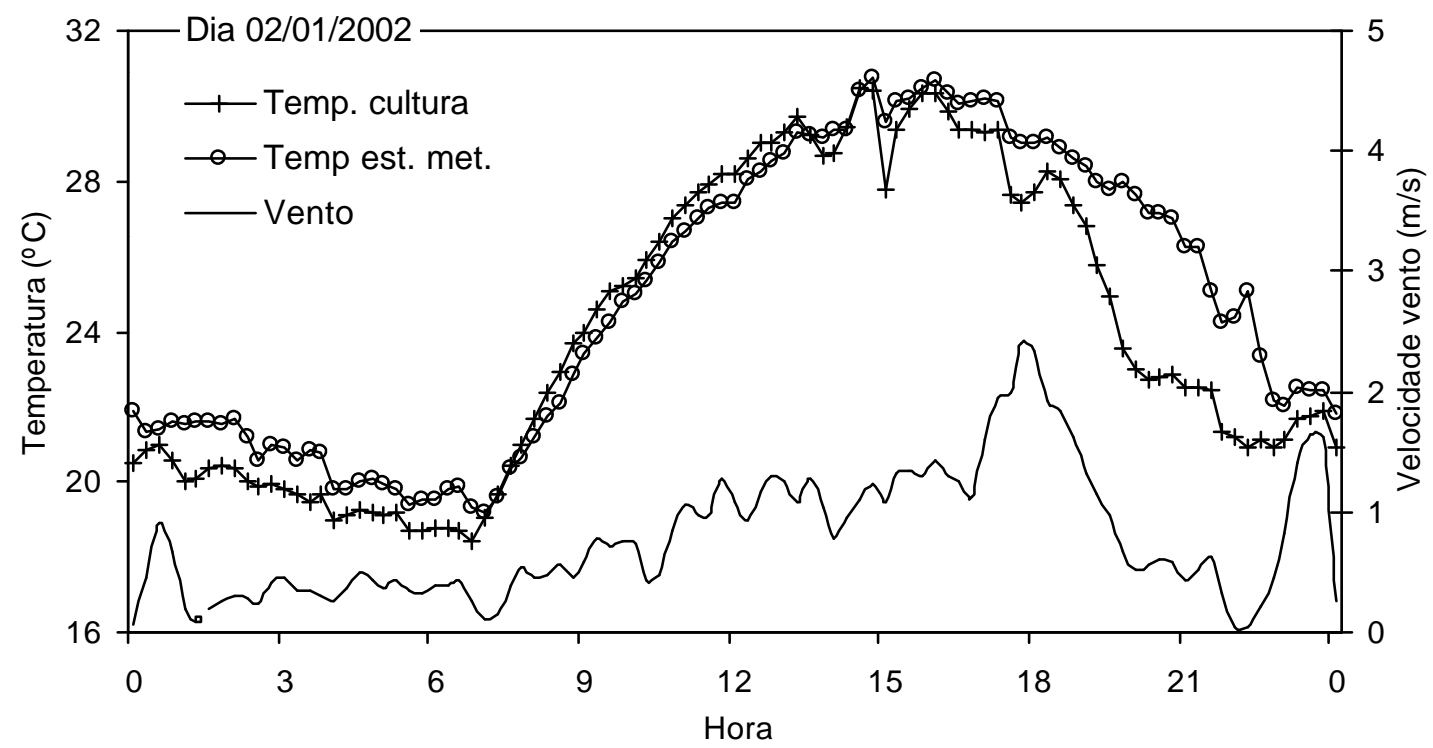

Figura 12 - Temperatura do ar na cultura do algodoeiro e na estação meteorológica padrão, e velocidade do vento, ao longo do dia 02 de janeiro de 2002.

Em vários dias analisados, foi comum ocorrer uma brusca redução da temperatura medida junto à cultura, o que sempre ocorria nos períodos vespertinos, após as horas mais quentes do dia e quando a temperatura passava a apresentar tendência decrescente. No entanto, esse fenômeno esteve sempre associado à baixa velocidade do vento. Verifica-se, neste caso (Figura 12), em que a diferença entre as temperaturas aumentou com a diminuição da velocidade do vento, no período entre 18 e $22 \mathrm{~h}$. Por outro lado, em outros dias analisados, nos horários em que a velocidade do vento se manteve acima de $1,5 \mathrm{~m} . \mathrm{s}^{-1}$ a diferença de temperatura entre as duas condições foi muito pequena.

É fato que durante todo o ciclo da cultura, em cerca de $85 \%$ do tempo, a diferença de temperatura entre a estação padrão e a cultura não excedeu a $1^{\circ} \mathrm{C}$. No entanto, em diversas momentos do ciclo foram constatadas diferenças significativas, as quais, sempre estiveram associadas à baixa velocidade do vento.

Como abordado por Rotem (1978), temperaturas desfavoráveis para o desenvolvimento da doença no campo, freqüentemente, inibem uma epidemia temporariamente. No entanto, em diversas situações desse tipo, identificadas durante o 
ciclo da cultura do algodoeiro, a diferença de temperatura nunca foi tal que pudesse caracterizar condição muito desfavorável ao patógeno. Nem por isso, a identificação do fenômeno deixa de ser relevante, uma vez que a temperatura afeta diretamente a velocidade de desenvolvimento do patógeno e, como abordado por Bedendo (1994), a temperatura esta relacionada com a maior ou menor duração da etapa de germinação de esporos e, conseqüientemente, de infecção. Dessa forma, estimativas de taxa de progresso de doença podem ser muito influenciadas por uma diferença de $4,6^{\circ} \mathrm{C}$ (como do exemplo), mesmo que por poucas horas, principalmente se durante períodos de molhamento e em condições de ocorrência de infecção.

\subsubsection{Umidade relativa}

Observou-se ao longo do ciclo do algodoeiro, um claro efeito do microclima, proporcionado pelas diferentes densidades populacionais, na umidade relativa do ar, ao contrário do observado para a temperatura. A Figura 13 apresenta a variação da umidade relativa do ar ao longo do ciclo da cultura, no intervalo de 0 a 120 DAE, monitorada em três condições distintas: nas parcelas da cultura em três densidades populacionais, na estação meteorológica padrão da área experimental e no Posto Meteorológico LCE/ESALQ/USP.

Obviamente, a fase inicial é marcada por uma condição uniforme na área experimental, uma vez que ainda não havia cultura, apenas solo nu preparado para a semeadura. A umidade relativa medida na estação meteorológica até os $30 \mathrm{DAE}$, se manteve menor que a do Posto Meteorológico. Dos 30 aos 45 DAE, intervalo marcado

por um significativo aumento do índice de área foliar da cultura, como indicado na Figura 10, constatou-se uma aproximação dos valores de umidade relativa, permanecendo similares até o final do ciclo quando, com o início da senescência das plantas, começou a haver novamente diferença.

Ao que parece, o crescimento da cultura e o conseqüiente aumento de fitomassa na área resultou em aumento de umidade relativa, identificável pelas medidas na estação meteorológica. As oscilações observadas na curva da estação meteorológica, 
de fase para fase, acompanharam as oscilações registradas no Posto Meteorológico, sendo, portanto, reflexos das condições meteorológicas da região.

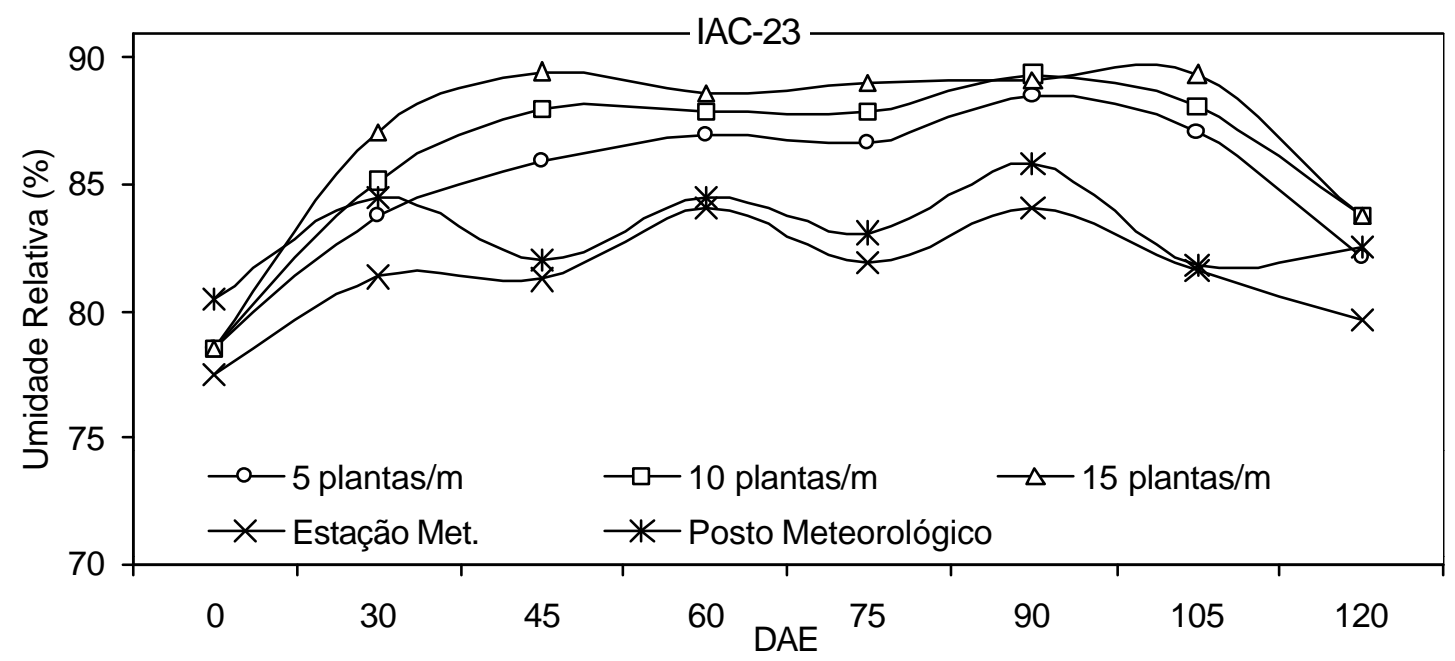

Figura 13 - Umidade relativa média do ar ao longo do ciclo da cultura do algodoeiro, medidas em cada densidade de plantio, na estação meteorológica da área experimental e no posto meteorológico (LCE/ESALQ/USP).

O que se verifica, é que a curva de umidade relativa, medida na estação, em um determinado nível, indica a intensidade dessa variável determinada pelas condições do tempo. Aquilo que excede esse nível é considerado como o efeito microclimático, gerado pela cultura, ou seja, é a própria intensidade da variável determinada pelas condições do tempo, acrescida do efeito provocado pela cultura. Nesse caso, da situação inicial de uniformidade, passando pelo progressivo aumento na área foliar das plantas, ocorre um distanciamento cada vez maior entre as medidas microclimáticas e as medidas da estação meteorológica. Isso ocorreu até os 45 DAE quando, a partir de então, a diferença permaneceu relativamente constante, até diminuir novamente, com a aproximação da senescência das folhas no final do ciclo.

É identificável, também, o efeito da densidade populacional no microclima. Paralelo à evolução do microclima em relação à condição geral, constatouse aumento de umidade relativa nas parcelas ou tratamentos com maior densidade. $\mathrm{Ou}$ 
seja, a umidade relativa foi maior na parcela com 15 plantas por metro, seguida das parcelas com 10 e 5 plantas por metro.

A diferenciação de microclimas entre as três densidades começou a ocorrer desde o início do desenvolvimento da cultura, e à medida que esta se desenvolveu, as diferenças tenderam a se ampliar até um determinado grau, quando entre 45 e 60 DAE, as diferenças passaram a diminuir, tornando-se muito menores ou mesmo insignificantes.

\subsubsection{Duração do período de molhamento foliar (DPM)}

\subsubsection{Avaliação dos sensores de molhamento foliar}

A medida da DPM foi realizada em dois períodos. Durante o período em que os sensores não estavam pintados com tinta látex, as medidas de DPM foram extremamente incoerentes entre os sete sensores utilizados (6 parcelas e estação padrão), ou seja, foi muito grande a diferença entre os valores de DPM registrados pelos sensores.

Na Figura 14a, que ilustra um dia de medida de dois sensores instalados na mesma condição microclimática (parcela com densidade populacional de 10 plantas por metro) antes da pintura, nota-se um grande desvio entre as curvas de cada sensor (linha contínua e linha descontínua). Esse desvio observado resultou em uma diferença de cerca de 10 h na DPM.

Após a pintura dos sensores com a tinta látex, as medidas passaram a ser mais coerentes, o que confirmou a importância do procedimento descrito por Gillespie e Kidd (1978). A Figura 14b ilustra um dia de medida dos mesmos sensores após a pintura. Neste caso, o desvio entre as curvas de cada sensor foi menor, reduzindo a diferença para cerca de $1,5 \mathrm{~h}$. 

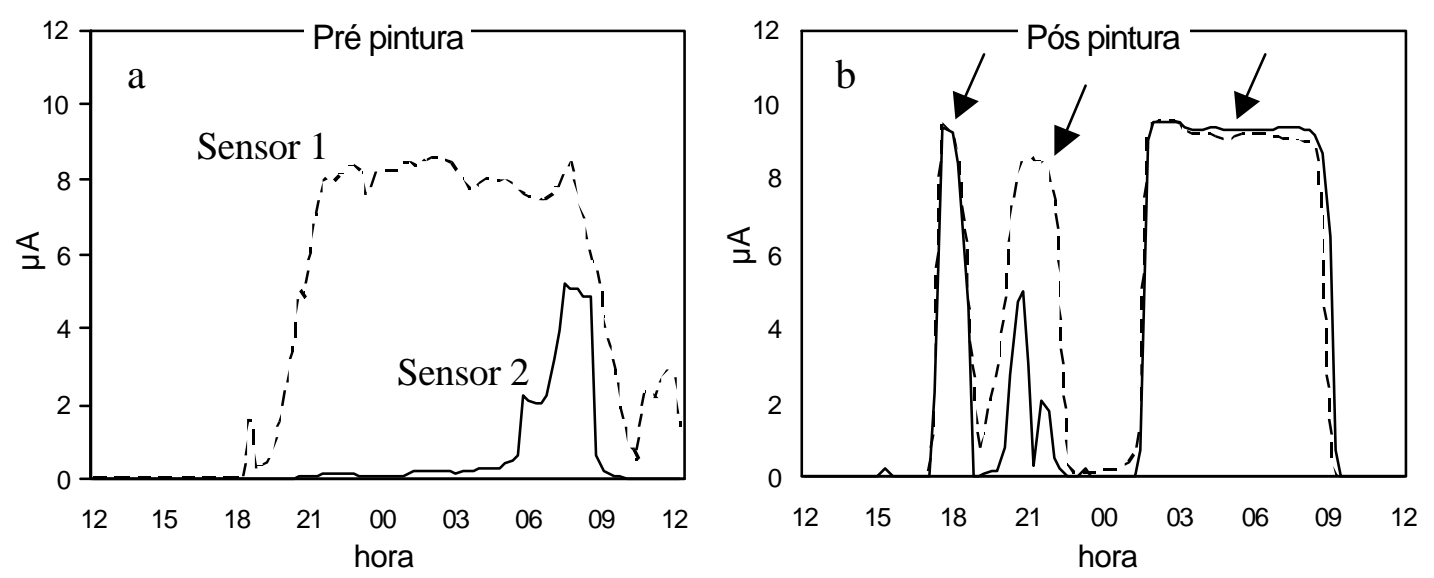

Figura 14 - Sinal elétrico de dois sensores de molhamento foliar, modelo 237 Campbell Scientific, instalados na cultura do algodoeiro nas seguintes condições: (a) sem pintura, dia 17/12/2001 e (b) com pintura, dia 17/03/2002.

A Figura 14b evidencia que as medidas não só diferem de um sensor para outro como, também, não é constante em um mesmo sensor ao longo do tempo. No primeiro pico de sinal (indicado pelas setas) as duas curvas são praticamente coincidentes, enquanto que no segundo pico, as curvas apresentam desvio entre si, o que gerou a diferença de cerca de $1,5 \mathrm{~h}$ entre as medidas. No terceiro e mais longo pico, as curvas voltam a ser praticamente coincidentes. Essas diferenças momentâneas ocorreram em todos os sensores utilizados, por diversos dias, e foram as principais causas das divergências observadas entre os sensores de DPM nas mesmas condições microclimáticas, mesmo comparando-se as médias de DPM ao longo dos 30 dias estudados, como mostra a Figura 15.

Essas diferenças, apesar de mostrarem o que ocorreu em um único dia, indicam um dos problemas associados a esse tipo de sensor de medida da DPM. Esses erros, muitas vezes podem ser grandes demais para se detectar diferenças no microclima, ou mesmo, para se tomar uma decisão. Uma a duas horas a mais de DPM pode significar a diferença entre condições para ocorrência, ou não, de infecção. 

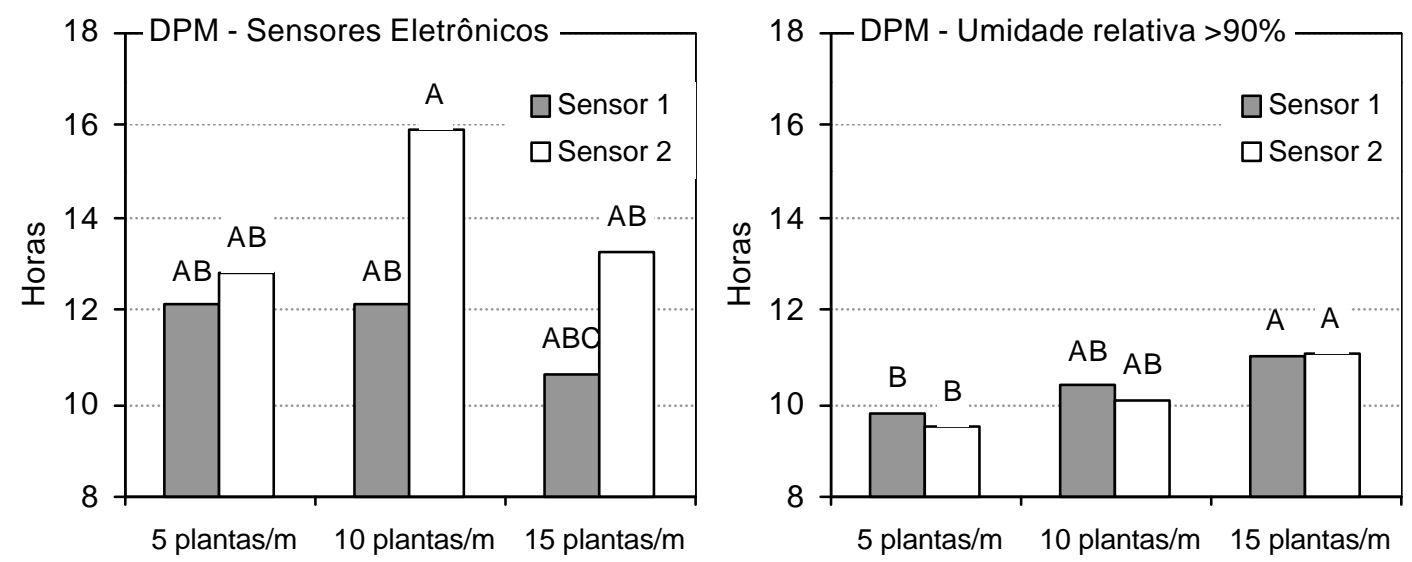

Figura 15 - Média diária da DPM, na cultura do algodoeiro, medida pelos sensores eletrônicos e estimada por NHUR $\geq 90 \%$, durante os 30 dias analisados. Barras com as mesmas letras não diferem estatisticamente entre si (Tukey a $5 \%)$.

Empregando-se a estimativa da DPM por meio da determinação do NHUR $\geq 90 \%$, obtidas pelo psicrômetro aspirado no interior da cultura, foi possível se verificar uma grande coerência entre a densidade populacional e a DPM (Figura 15), sendo esta maior na densidade de 15 plantas por metro, o que, no entanto, não foi detectado pelos sensores eletrônicos de DPM.

Portanto, todas as considerações e dados apresentados acerca da DPM verificada no experimento, serão baseados nas estimativas a partir do método que corresponde ao NHUR $\geq 90 \%$.

\subsubsection{Duração do período de molhamento foliar na cultura}

A Figura 16 apresenta valores totais diários de DPM e precipitação de uma semana, tomada como exemplo, durante o ciclo da cultura. Observa-se uma sequiência de eventos bastante ilustrativa para a análise das condições do tempo e do microclima da cultura do algodoeiro. 


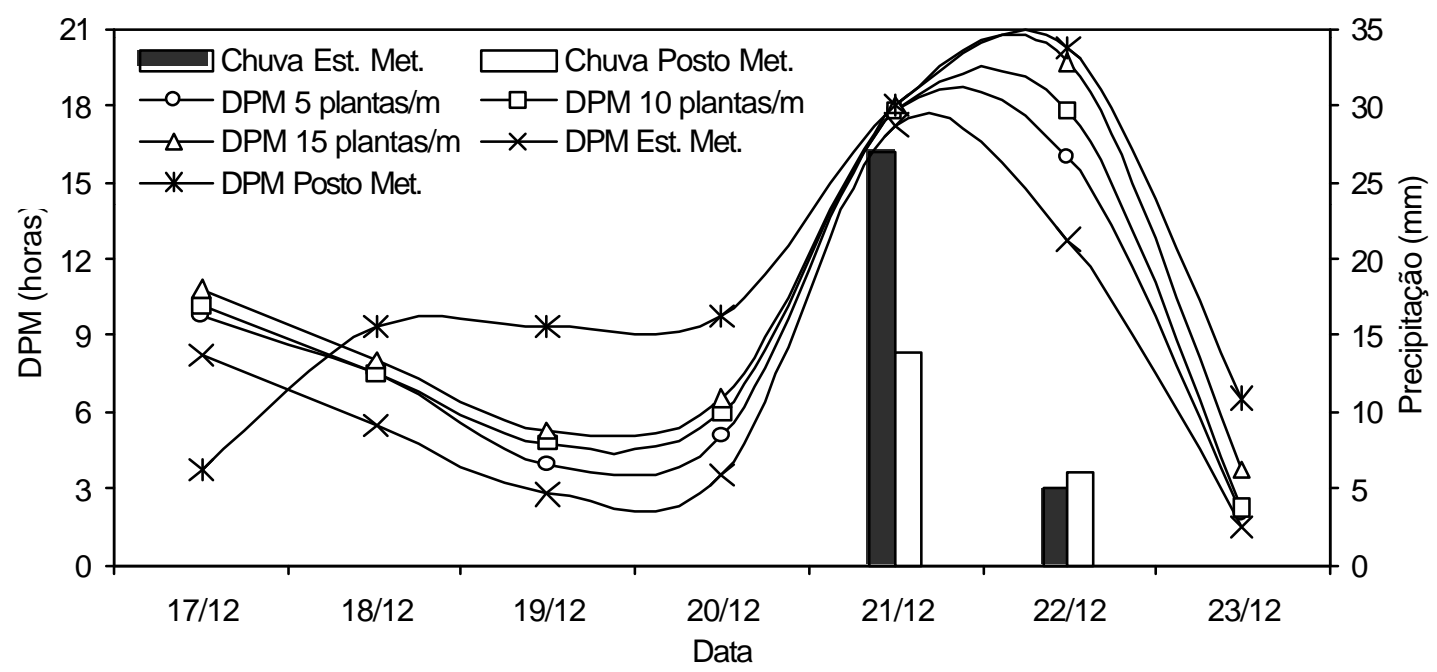

Figura 16 - Duração do período de molhamento e precipitação em uma fase do ciclo da cultura do algodoeiro, medidas em cada densidade populacional, na estação meteorológica da área experimental e no posto meteorológico (LCE/ESALQ/USP).

No início do período, comparando-se a DPM medida pelos conjuntos sensores nos diferentes tratamentos, ou seja, junto ao dossel da cultura em cada densidade populacional, verifica-se valores de DPM muito similares. No entanto, mesmo nesse período evidencia-se um discreto acréscimo de DPM quando se comparam as parcelas com diferentes densidades populacionais.

A diferença entre a DPM nos tratamentos e na estação meteorológica padrão, no centro da área experimental, se deve à diferença de posicionamento da medida, dada a maior proximidade do conjunto sensor à zona de maior influência da cultura (junto ao dossel). Isto significa que, normalmente, uma variável medida em uma estação meteorológica não reflete a condições m cultura. De 17/12 a 20/12, a diferença entre os dois pontos de medida foi de $2,1 \mathrm{~h}$, valor considerável em se tratando de estudos epidemiológicos, já que uma diferença como essa pode ser suficiente para possibilitar ou inviabilizar a ocorrência de infecção.

A área experimental e o Posto Meteorológico encontravam-se, praticamente, na mesma altitude e distando cerca de $5 \mathrm{~km}$ um do outro. Mesmo assim, 
diferenças importantes de DPM foram observadas entre os dois locais. No dia 17/12, a DPM no Posto Meteorológico foi cerca de 4,4 h menor que na estação e, no dia 19/12, foi 6,6 h maior que na estação meteorológica. Tais observações refletem a variabilidade espacial e temporal das condições do tempo e, também, o quanto as condições para o desenvolvimento de uma doença podem ser variáveis em um curto intervalo de tempo, e ainda, que isso é perfeitamente identificável e mensurável, desde que com os instrumentos e métodos apropriados.

Durante o mesmo período, de 17 a 20/12, a diferença entre a DPM na estação meteorológica e nos tratamentos praticamente se manteve a mesma. Ocorreu apenas uma pequena diferença entre os tratamentos, que chegou a $1 \mathrm{~h}$ entre a menor e a maior densidade populacional. A precipitação de $27 \mathrm{~mm}$ ocorrida no experimento no dia 21/12 igualou a medida de DPM tanto nos tratamentos como na estação meteorológica e no Posto Meteorológico, em torno de $18 \mathrm{~h}$.

A diferenciação clara dos microclimas quanto à DPM ocorreu após a chuva que, na área experimental, se iniciou no dia 21 e terminou no dia 22/12. A partir do fim da chuva, por volta das 8 h do dia 22, a água remanescente sobre as partes das plantas, progressivamente evaporou. Quanto maior a densidade populacional menor a ação do vento e da incidência de radiação solar no interior da cultura, retardando a evaporação. Segundo Pedro Júnior (1989), o incremento da densidade populacional de uma cultura afeta marcadamente o balanço de energia radiante e, conseqüentemente, a velocidade de evaporação de água proveniente de chuva, orvalho ou irrigação. Como descrito por Baker et al. (1972) e Benedict (1984), o algodoeiro apresenta estrutura planofoliar do dossel, com elevadíssimo coeficiente de extinção de luz. Isso resulta em alterações microclimáticas que afetam o curso diário da umidade e da temperatura dentro do dossel das plantas, favorecendo o desenvolvimento de epidemias (Rotem \& Palti, 1969 e Pedro Jr., 1989). Como resultado, registrou-se 19,8 h de DPM na parcela mais densa, 17,8 h na parcela de densidade intermediária e $16 \mathrm{~h}$ na menos densa, ao passo que a DPM foi de 12,8 h na estação meteorológica. 
Após a evaporação da água da chuva, a situação novamente tende a um equilíbrio, onde acaba persistindo apenas uma pequena diferença entre os microclimas quanto à DPM causada, provavelmente, pelo orvalho. É o que se observa no dia 23/12.

As condições micrometeorológicas monitoradas em cada parcela parecem sempre tender ao equilíbrio em condições de tempo estável. No entanto, as diferenças registradas entre elas parecem estar mais relacionadas com a velocidade com que as condições dentro das parcelas entram em equilíbrio com a nova condição de tempo predominante. Obviamente, essa velocidade de transição que leva ao equilíbrio depende de dois fatores: da magnitude da diferença da variável entre o ambiente e o interior da cultura; e das características estruturais da cultura (altura, IAF), que influenciam a evaporação da água (influi na umidade e DPM) e, basicamente, definem dois espaços diferentes - o espaço da cultura, ou a foliosfera, e a atmosfera na qual está inserida.

A Figura 17 ilustra a DPM ao longo do ciclo da cultura, no intervalo de 0 a 120 DAE, monitorada em três condições distintas: nas parcelas da cultura em três densidades populacionais, na estação meteorológica padrão da área experimental e no Posto Meteorológico da ESALQ/USP.

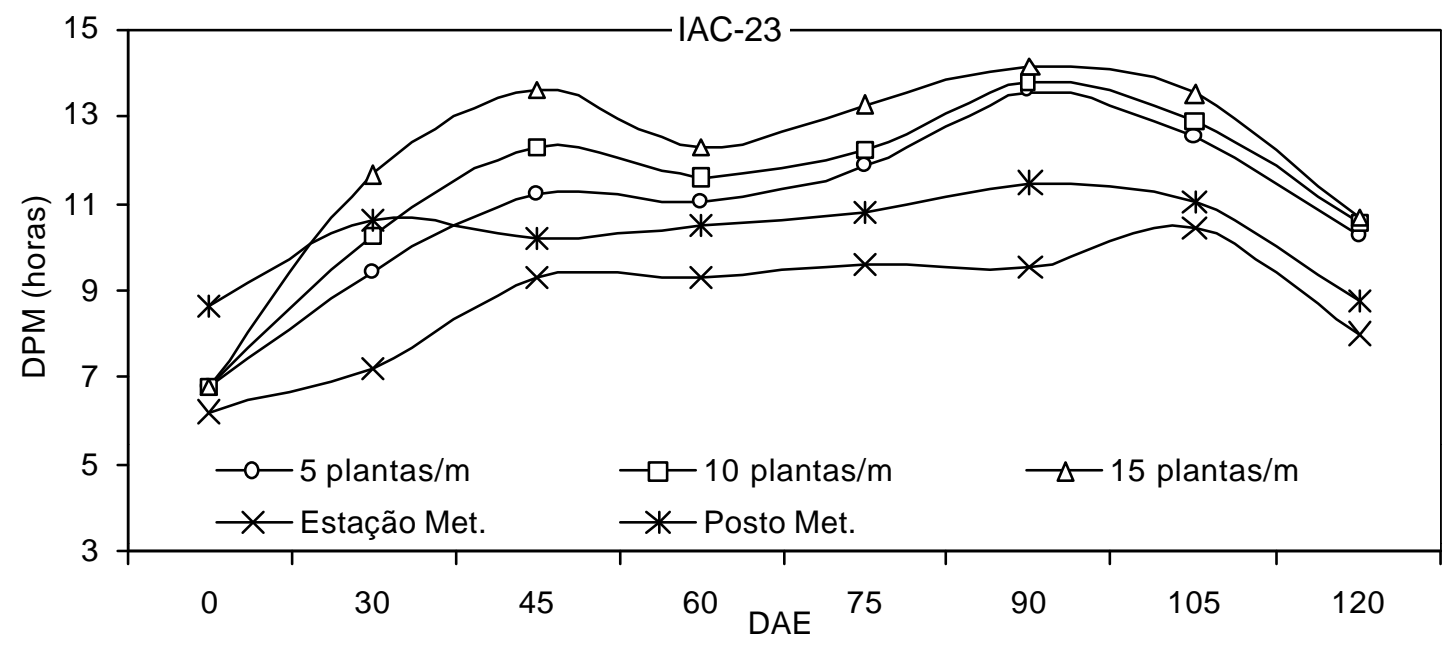

Figura 17 - Duração média do período de molhamento ao longo do ciclo da cultura do algodoeiro, medidas em cada densidade de plantio, na estação meteorológica da área experimental e no posto meteorológico (LCE/ESALQ/USP). 
Uma vez que foi estimada pela umidade relativa, a DPM apresentou variação similar às curvas de umidade relativa, porém, com algumas diferenças importantes. A DPM medida na estação meteorológica se manteve menor que a do Posto Meteorológico. Dos 30 aos 45 DAE, intervalo marcado por um significativo aumento da área foliar da cultura, constatou-se uma aproximação dos valores, havendo redução da diferença. O crescimento da cultura e, conseqüiente aumento da fitomassa, resultou em aumento de umidade relativa, que por sua vez resultou em aumento mais que proporcional na DPM.

Observa-se um claro efeito do microclima na DPM, mais do que na umidade relativa. Nesse caso, ao longo do crescimento da cultura, ocorreu uma diferença cada vez maior entre aDPM na cultura e a da estação meteorológica. Isso ocorreu até, aproximadamente, os 45 DAE quando, a partir de então, a diferença diminuiu e tornou a aumentar até $90 \mathrm{DAE}$

É identificável, também, o efeito da densidade populacional na DPM (Figura 17). Paralelo à evolução do microclima em relação à condição geral, é constatado aumento da DPM nas parcelas ou tratamentos com maior densidade. Ou seja, a DPM foi maior na parcela com 10 plantas por metro do que na de 5 plantas e, maior ainda nas parcelas com 15 plantas por metro. Sentelhas (1992), também constatou diferença significativa entre a DPM de diferentes densidades populacionais de trigo, principalmente em um ano com poucas chuvas.

A diferenciação de microclimas entre as densidades começou a ocorrer desde as fases iniciais do desenvolvimento da cultura, e à medida que esta se desenvolveu, as diferenças tenderam a se ampliar até um determinado grau, quando entre 45 e 60 DAE, as diferenças diminuíram progressivamente, se tornando cada vez menores, tendendo a igualdade.

$\mathrm{Na}$ fase inicial, de 0 a 45 DAE, quando as condições microclimáticas entre as densidades foram mais discrepantes, a diferença chegou, em média, a $1 \mathrm{~h}$ entre as densidades de 5 e 10 plantas por metro, e 1,5 h entre as densidades de 10 e 15 plantas por metro, ou seja, 2,5 h entre a maior e a menor densidade. É claro que essas diferenças são apenas médias de 7 dias de cada fase analisada, o que significa que em vários dias a 
diferença foi menor que essa, mas o que é mais importante, é que em outros tantos dias, a diferença foi ainda maior que 2,5 h. E são, exatamente, casos como esses, que irão possibilitar a ocorrência de diferentes intensidades de doença em distintas densidades populacionais.

\subsection{Considerações gerais sobre o microclima da cultura}

As diferenças microclimáticas ocorreram basicamente na fase inicial da cultura. Partiu-se de uma situação inicial sem diferenças em razão da ausência de vegetação. A partir da emergência e início do desenvolvimento das plantas, iniciou-se a diferenciação dos microclimas formados de acordo com a densidade populacional de cada parcela.

As diferenças nas variáveis meteorológicas seguiram se ampliando, até atingir um ponto máximo e novamente tender a uma situação de uniformidade entre os microclimas, mesmo embora a densidade de fitomassa e índice de área foliar continuassem diferentes e, até mesmo, se ampliando. Logo, é provável que o condicionamento do microclima pela cultura ocorra até um certo limite, a partir do qual o aumento da densidade vegetal não resulta mais em interferência.

Mesmo assim, no caso do uso de plantios adensados, é válido afirmar que é muito provável que o microclima resultante do adensamento favoreça o desenvolvimento de doenças, uma vez que um dos reflexos dessa prática foi o aumento da umidade e da duração do período de molhamento foliar.

Também é válido afirmar que isso se aplica principalmente para a fase inicial da cultura e que, posteriormente, perde importância a partir de uma determinada fase, quando as diferenças microclimáticas causadas pelo adensamento deixam de ser relevantes.

A comprovação dessas duas afirmativas depende, também, das condições do tempo durante o ciclo da cultura. Como demonstrado anteriormente, o efeito do microclima é limitado e, em geral, é representado pelo efeito aditivo (maior umidade e DPM) ou subtrativo (menor temperatura) na intensidade das variáveis meteorológicas 
predominantes na região, condicionados pelos fatores macroclimáticos. Nesse caso, a intensidade das modificações do microclima é variável de ano para ano.

Em anos que o clima é favorável à ocorrência da doença, o efeito aditivo de umidade ou DPM do microclima se torna menos importante, pois as condições ótimas para o desenvolvimento da doença já são proporcionadas pelo macroclima. Em anos que o clima é desfavorável para a ocorrência da doença o efeito aditivo do microclima pode ser importante à medida que o acréscimo de umidade ou DPM pode significar a elevação dessas variáveis de um patamar antes desfavorável para um mais favorável ao patógeno. Rotem (1978) afirma que sob condições climáticas muito favoráveis ou desfavoráveis à doença, nem a densidade da cultura, nem a irrigação causam efeito sobre o desenvolvimento dos patógenos. Concluiu, ainda, que o mesmo não ocorre em condições marginais, nas quais esses fatores de natureza microclimática são fundamentais para o estabelecimento do processo infeccioso.

Isso pode ser ilustrado supondo-se que a DPM mínima necessária para que conídios de Colletotrichum gossypii var. cephalosporioides pudessem completar a etapa de infecção fosse de $12 \mathrm{~h}$, na faixa de temperatura de 22 a $24^{\circ} \mathrm{C}$.

Confrontando as duas condições hipotéticas, de temperatura e de DPM, com os dados observados na condução do experimento, verifica-se que no período do 0 aos 60 DAE a condição de temperatura foi atendida. No entanto, como ilustrado pela Figura 18, a condição de DPM não foi atendida igualmente nas três densidades populacionais estudadas. Nota-se que a DPM medida na parcela com densidade de 5 plantas por metro não atingiu a condição hipotética mínima de $12 \mathrm{~h}$. Por outro lado, na densidade de 10 plantas por metro o patamar mínimo é atingido por volta dos 45 DAE apenas. Na densidade de 15 plantas por metro, a condição mínima, por sua vez, é atingida logo após os $30 \mathrm{DAE}$, permanecendo acima do mínimo exigido pelo patógeno até os 60 DAE. Em contraste, a DPM registrada na estação meteorológica em nenhum momento ultrapassou o patamar de 9,5 h. Tal fato concorda com o exposto por Agrios (1997), que afirma que técnicas de cultivo intensivo podem transformar ambientes adversos em ambientes favoráveis ao desenvolvimento de doenças. 


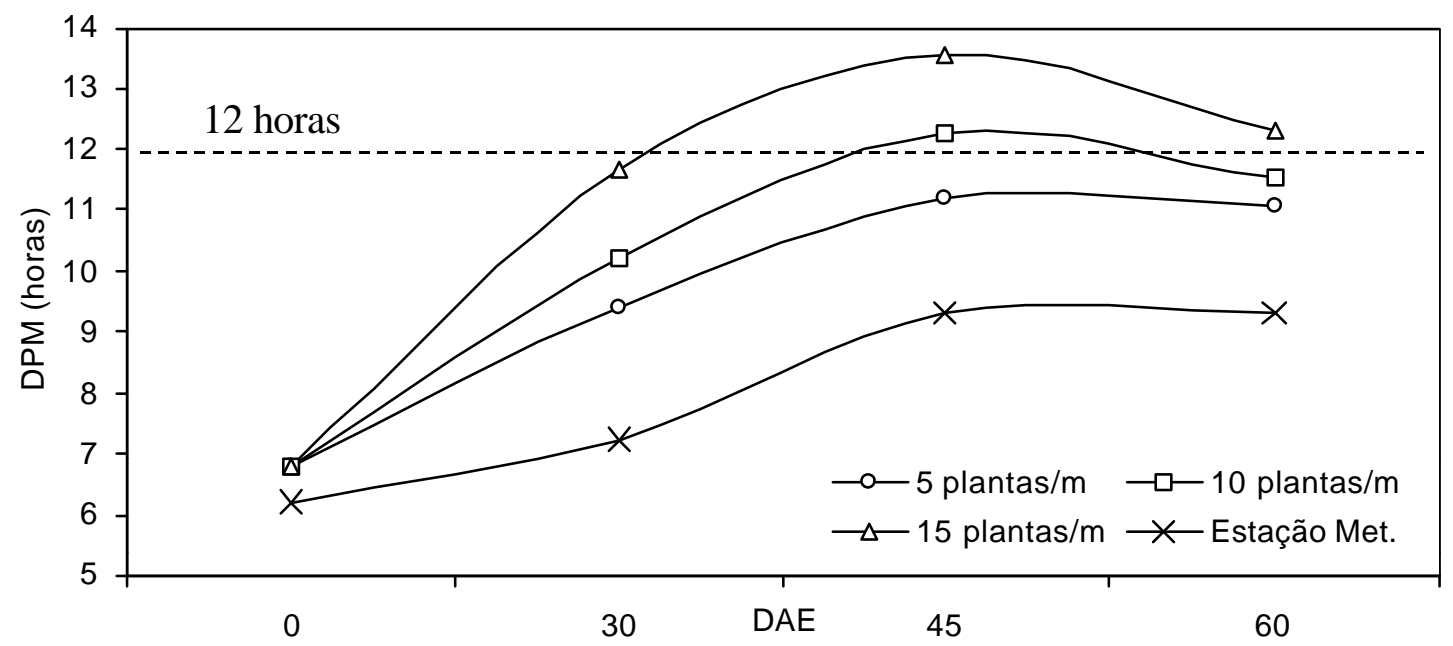

Figura 18 - Duração média do período de molhamento, entre 0 e 60 DAE, em cada densidade de plantio e na estação meteorológica da área experimental. A linha pontilhada indica o período mínimo hipotético de molhamento necessário (12 h) para ocorrência de infecção entre 22 e $24^{\circ} \mathrm{C}$.

Com base nessas informações não é possível afirmar que a doença não ocorreria na densidade de 5 plantas por metro, uma vez que, m Figura 18, é apresentado apenas como evoluiu a DPM nas diferentes densidades, em termos médios, não considerando a variabilidade diária ocorrida no período. Portanto, o acompanhamento e a análise do microclima da cultura deve ser feito, sempre que possível, na escala diária.

Deve ser enfatizado, entretanto, que a utilização da DPM, em termos médios, no presente estudo, já permitiria inferir que maior intensidade de doença ocorreria na densidade de 15 plantas por metro, e menor intensidade na densidade de 5 plantas por metro. Como discutido por Agrios (1997), a extensão e a frequiência da ocorrência de determinada doença, assim como sua severidade, são influenciadas pelo grau de desvio de cada condição ambiental do ponto no qual o desenvolvimento da doença é ótimo. 


\subsection{Ocorrência de ramulose na cultura do algodoeiro}

\subsubsection{Curvas de Progresso da Doença}

Na Figura 19 são apresentadas as curvas de progresso da ramulose, expressas pela severidade da doença, avaliada no intervalo de 0 a 130 DAE, nas parcelas da cultivar IAC 23, nas três densidades populacionais: 5, 10 e 15 plantas por metro.

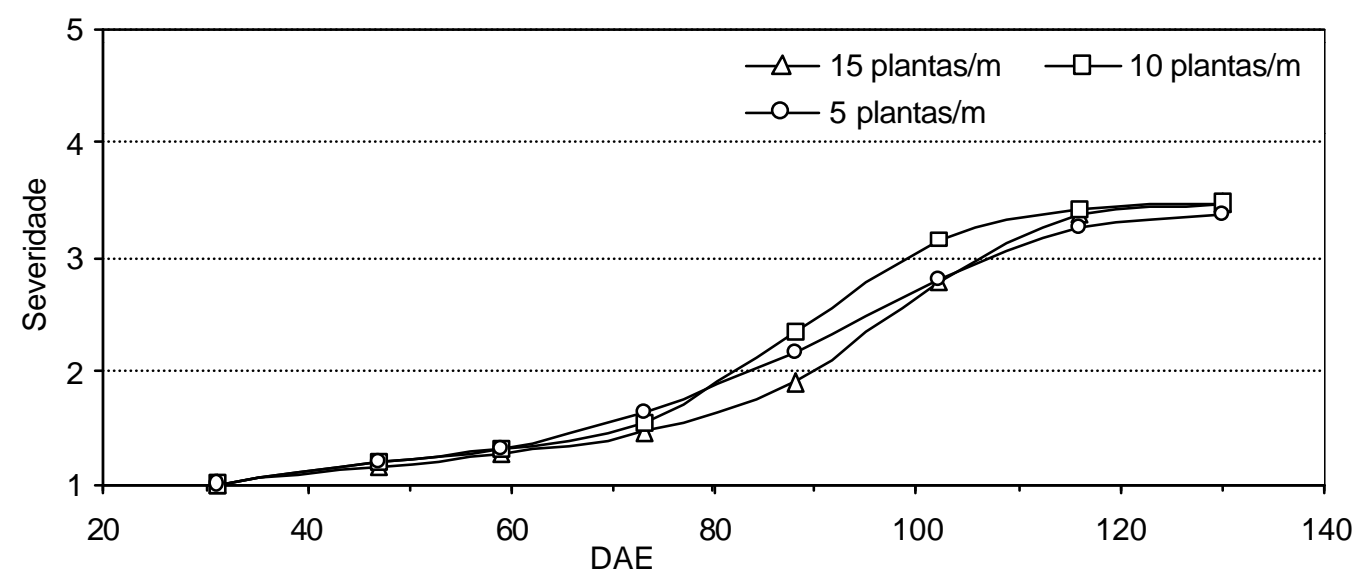

Figura 19 - Severidade média de ramulose na cultura do algodoeiro, nas parcelas inoculadas da cultivar IAC 23.

Analisando-se as curvas da Figura 19, constata-se, claramente, a mudança de magnitude de severidade da doença ao longo do tempo. De início, a severidade da ramulose aumentou lentamente, passando por uma fase de aumento da taxa de crescimento no período entre as avaliações de 73 a 102 DAE. Após a avaliação dos 102 DAE, e com a aproximação do fim do ciclo da cultura, a taxa de crescimento da doença diminuiu, até a nulidade, e os valores de severidade mantiveram-se praticamente constantes.

Para o caso da cultivar Coodetec 401, ao contrário do que ocorreu com a cultivar IAC 23, o aumento da severidade da doença foi rápido, desde o início, como pode ser observado na Figura 20. Como conseqüência disso, a severidade, avaliada nas 
parcelas desta cultivar, foi sempre maior do que na IAC 23, inclusive, atingindo o máximo grau de severidade, representado pela nota 5, o que não ocorreu na IAC 23.

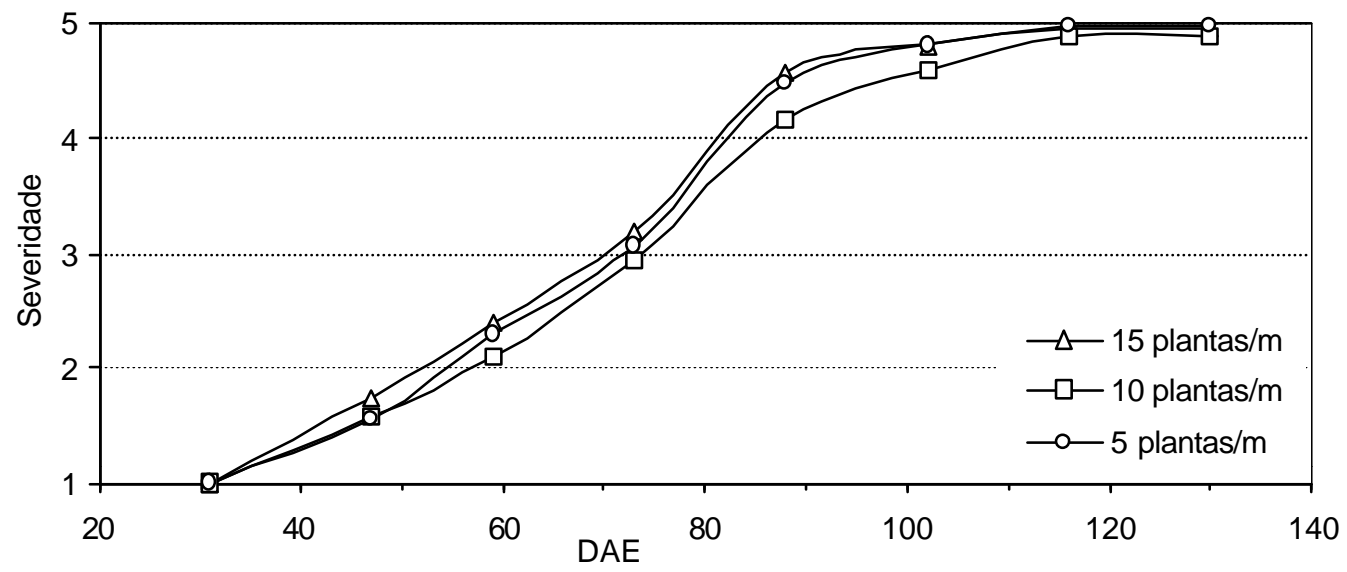

Figura 20 - Severidade média de ramulose na cultura do algodoeiro, nas parcelas inoculadas da cultivar Coodetec 401.

Assim como na cultivar IAC 23, nas avaliações da altivar Coodetec 401 não se constatou diferenças significativas de severidade em função da densidade populacional, ou seja, não houve efeito da densidade da cultura no progresso da doença. Dessa forma, se considerarmos uma curva única de progresso da severidade para cada cultivar, determinada pela média dos valores de severidade de cada densidade, é possível comparar a taxa de crescimento da doença para cada cultivar (Figura 21).

A partir da primeira inoculação aos $31 \mathrm{DAE}$, originaram-se as primeiras lesões. As lesões primárias serviram como fonte de inóculo para as lesões secundárias e, o patógeno propagando-se radialmente, formou reboleiras, assim como descrito por Cia \& Salgado (1995), o que resultou em um aumento na incidência e, conseqüentemente, na severidade média, também.

$\mathrm{Na}$ verdade, a segunda inoculação aumentou pouco a incidência em relação à avaliação anterior e, exatamente por isso, os valores de severidade determinados pela média de 10 plantas avaliadas por parcela - não foram muito afetados. É bastante provável, porém, que o número de lesões por planta tenha aumentado proporcionalmente com a segunda inoculação mas, como número de lesões 
não interfere na atribuição das notas de severidade da escala empregada, as médias por parcela e cultivar pouco se alteraram.

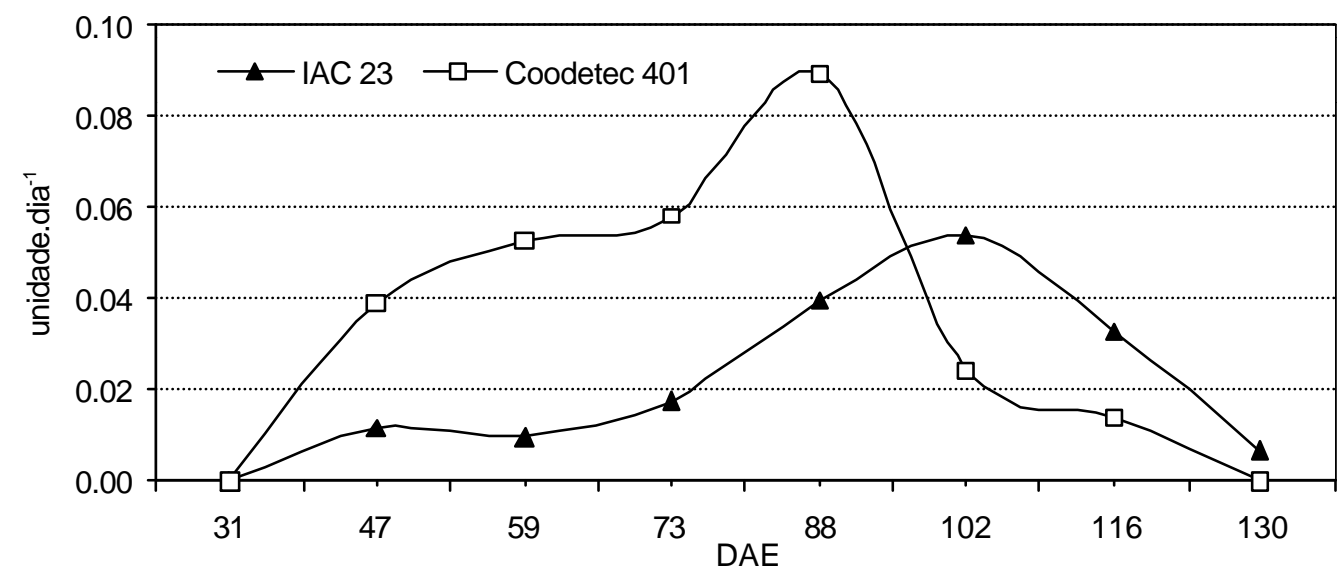

Figura 21 - Taxa de crescimento da ramulose na cultura do algodoeiro, parcelas inoculadas, cultivares IAC 23 e Coodetec 401.

De forma geral, como apresentado na Figura 21, a comparação das taxas de crescimento da doença registradas nas cultivares, reflete a maior suscetibilidade da cultivar Coodetec 401 a ramulose, na qual a taxa de crescimento foi maior desde o início da epidemia. Na avaliação aos 102 DAE, a situação se inverteu, ou seja, a taxa de crescimento na Coodetec 401 se tornou menor que na cultivar IAC 23. Isso ocorreu por que nessa época, os valores de severidade da doença já tinham atingido grau máximo, não sendo possível um crescimento acelerado.

Como pode ser observada na Figura 22, por volta do 60 DAE, a incidência da doença na cultivar IAC 23 foi próxima a $28 \%$. No mesmo período, na cultivar Coodetec 401, a incidência atingiu 100\% (Figura 23). Considerando-se que, nas duas cultivares o processo de inoculação e a solução inóculo utilizada foram os mesmos, é possível prever que a quantidade de inóculo depositada nas parcelas das duas cultivares tenha sido, praticamente, a mesma. Nesse caso, deduz-se que um dos mecanismos de resistência à doença, da cultivar IAC 23 em relação a Coodetec 401, atua na etapa de infecção pelo patógeno. $O$ aumento da incidência na cultivar IAC 23 vinha apresentando uma tendência de crescimento lento desde o início da epidemia, com 
aumentos decrescentes entre avaliações até o intervalo entre 87 e 101 DAE, quando houve um aumento acentuado, de quase 2,5 vezes, passando de $37 \%$ para $91 \%$ em média (Figura 22).

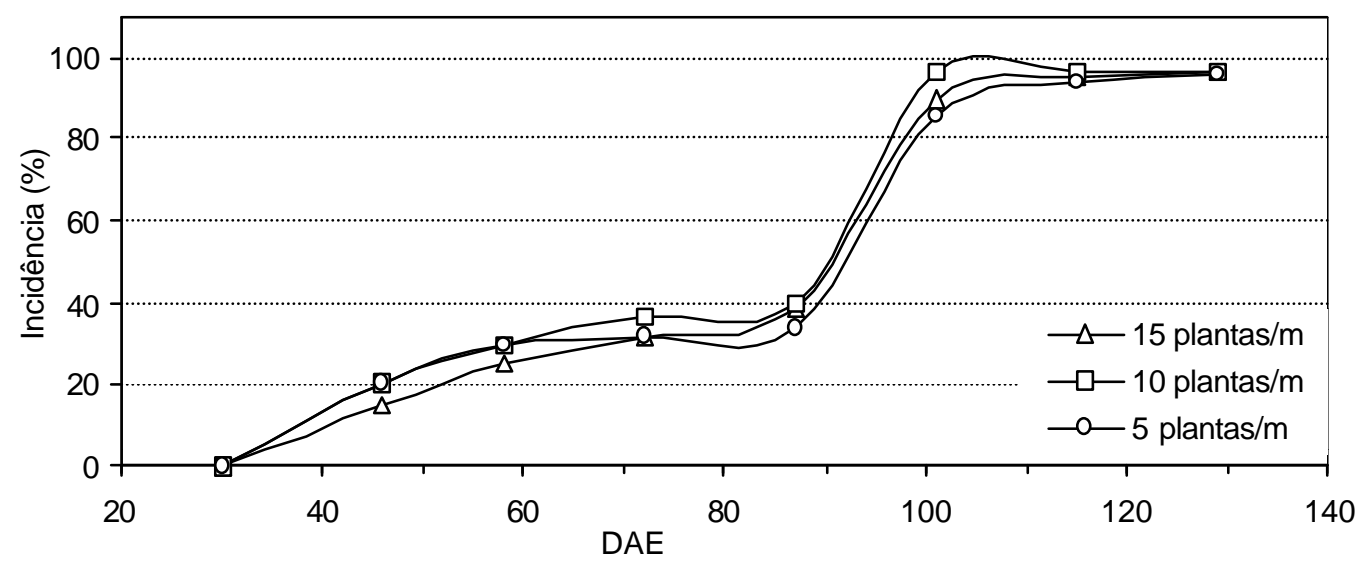

Figura 22 - Incidência de ramulose, em valores percentuais na cultura do algodoeiro, nas parcelas inoculadas da cultivar IAC 23.

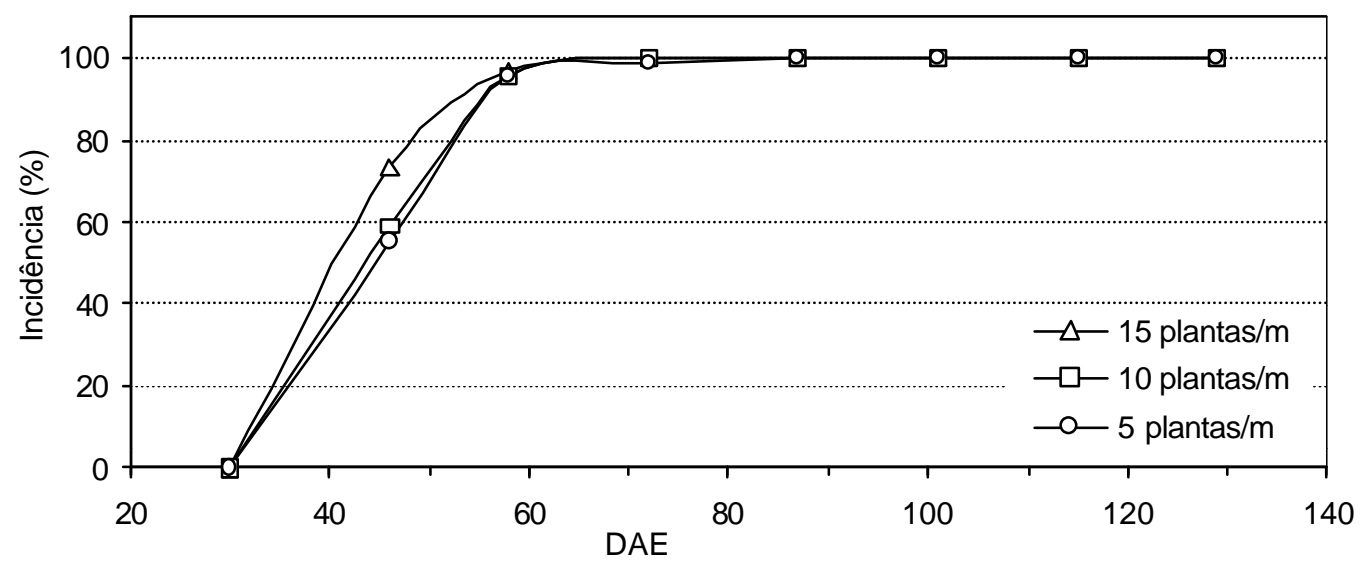

Figura 23 - Incidência de ramulose, em valores percentuais na cultura do algodoeiro, nas parcelas inoculadas da cultivar Coodetec 401.

Como ilustrado na Figura 24, as plantas das parcelas não inoculadas começaram a apresentar sintomas da doença a partir de 87 DAE. Neste caso, no entanto, não houve diferença significativa entre as cultivares, que apresentaram valores médios 
de severidade muito próximos, um pouco maiores na Coodetec. Provavelmente, isto ocorreu devido ao fato das plantas estarem com a altura definida e com crescimento vegetativo mais lento, não propiciando tempo suficiente nem condições para superbrotamento e redução relativa do porte - condições necessárias para notas maiores que 3. Neste caso, mais próximo ao final do ciclo, não houve possibilidade da severidade da doença ultrapassar o patamar em torno de 3, tanto na cultivar resistente (IAC 23) como na suscetível (Coodetec 401). A manifestação tardia da doença originou a denominação ramulose tardia, de sintomas muito semelhantes. Entretanto, plantas doentes apresentam o superbrotamento, quando apresentam, só no ápice, não afetando muito o rendimento (Abrahão, 1961; Cia \& Salgado, 1995).
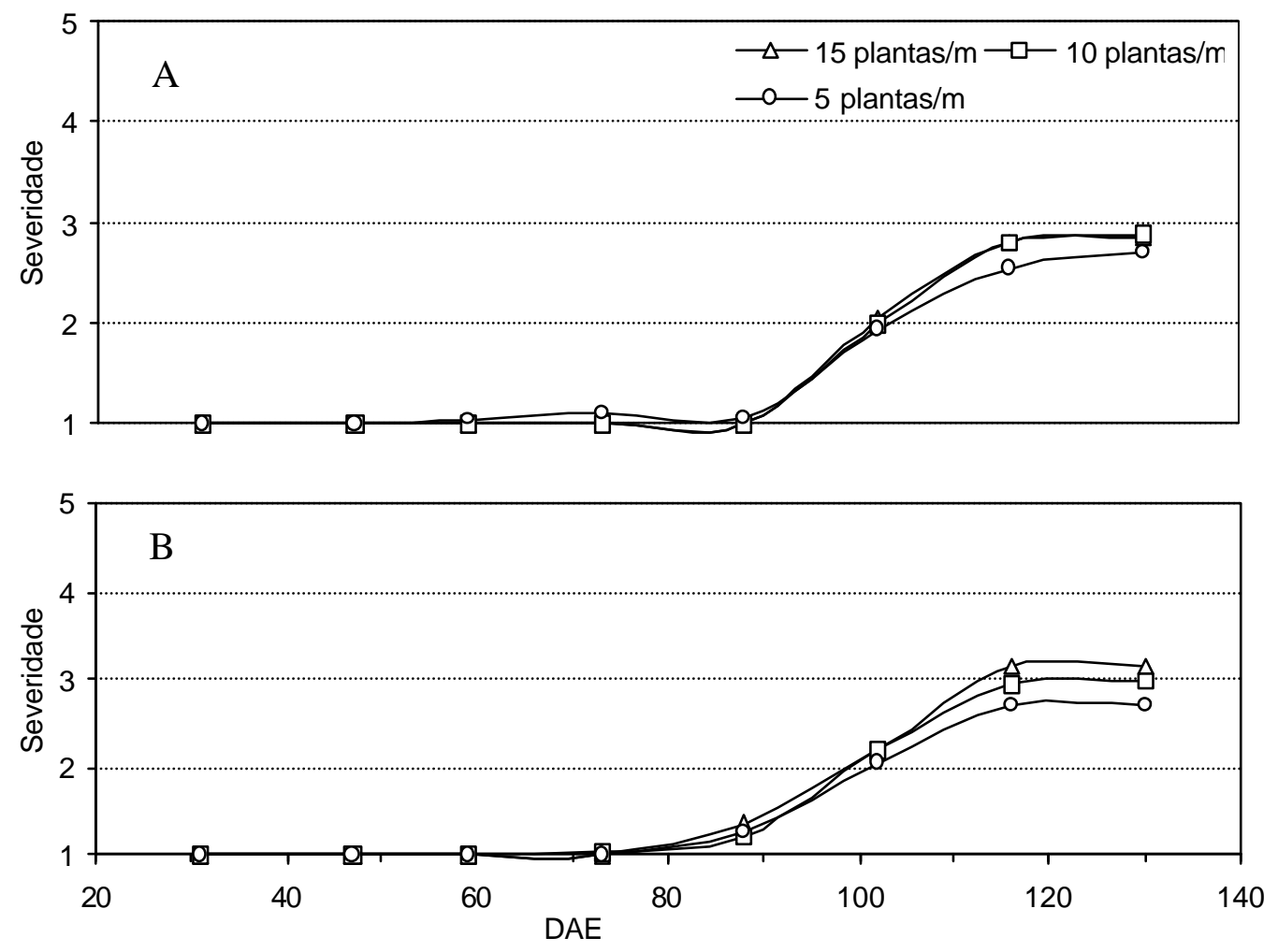

Figura 24 - Severidade de ramulose na cultura do algodoeiro, nas parcelas não inoculadas da cultivar IAC 23 (A) e Coodetec 401 (B). 
A principal diferença entre o progresso da doença nas parcelas não inoculadas, se comparadas às inoculadas, foi que a intensidade da doença foi igual nas duas cultivares. Por outro lado, o aparecimento dos sintomas nas duas cultivares das parcelas não inoculadas ocorreu simultaneamente ao aumento da incidência na cultivar IAC 23, como descrito anteriormente e ilustrado na Figura 22. Provavelmente, isso deve estar associado a um conjunto de condições meteorológicas altamente favoráveis à ocorrência de infecção, de modo que, tanto a cultivar resistente como a suscetível, desenvolveram a doença em igual intensidade.

Analisando-se as curvas de taxa de crescimento da doença nas parcelas não inoculadas, apresentadas na Figura 25, constata-se que a ocorrência de doença foi detectada na cultivar Coodetec 401 antes que na IAC 23 pois, na avaliação dos 87 DAE, a taxa de crescimento observada foi de $26 \%$ na Coodetec 401 e nula na IAC 23. Se foi, realmente, a ocorrência de condições meteorológicas específicas de um período que resultaram nesse aumento brusco de intensidade nas duas cultivares, estas condições favoreceram mais a ocorrência de infecção do que a colonização pelo patógeno. Isso porque, nesta situação, o aumento de incidência foi o mesmo nas duas cultivares, ou seja, a taxa de infecção foi igual, mas o período de incubação permaneceu maior na IAC 23.

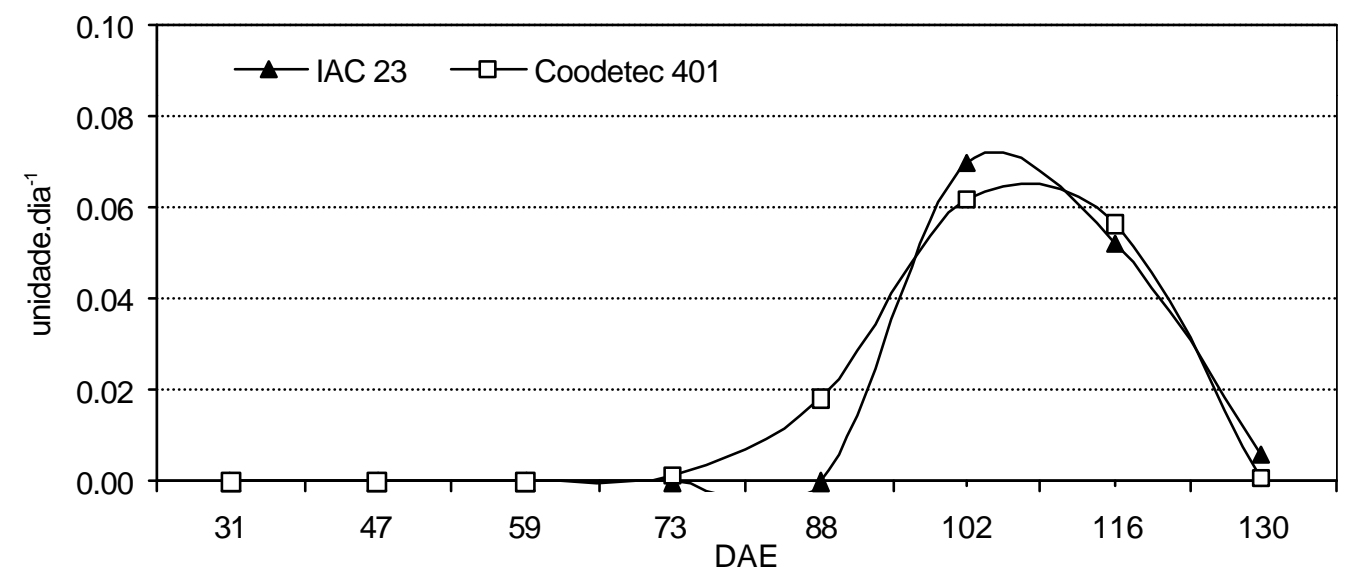

Figura 25 - Taxa de crescimento da ramulose no algodoeiro, parcelas não inoculadas, cultivares IAC 23 e Coodetec 401. 
A Figura 26 ilustra o progresso da incidência da doença nas parcelas não inoculadas da cultivar IAC 23. No intervalo de 87 a 101 DAE, foi verificado um aumento de $2 \%$ para $94 \%$, em média, e de $0 \%$ para $100 \%$, no caso mais grave, nas parcelas de densidade de 15 plantas por metro.

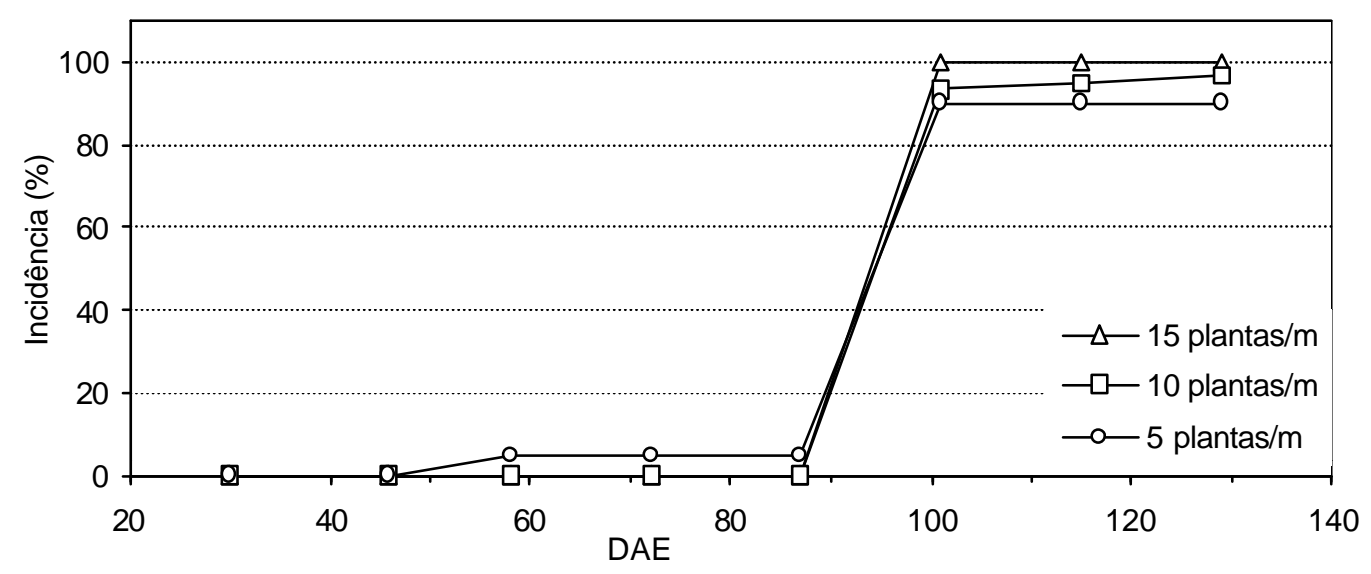

Figura 26 - Incidência de ramulose na cultura do algodoeiro, nas parcelas não inoculadas da cultivar IAC 23.

A Figura 27 ilustra o progresso da incidência da doença nas parcelas não inoculadas da cultivar Coodetec 401. No intervalo 87 a 101 DAE, foi verificado um aumento de $36 \%$ para $90 \%$ em média e de $22 \%$ para $90 \%$, no caso mais grave, nas parcelas de densidade de 10 plantas por metro. Ao contrário do caso anterior, em que a doença na cultivar IAC 23 só se manifestou claramente depois dos 87 DAE, na cultivar Coodetec 401, o acelerado aumento na incidência já foi detectado aos 87 DAE. 


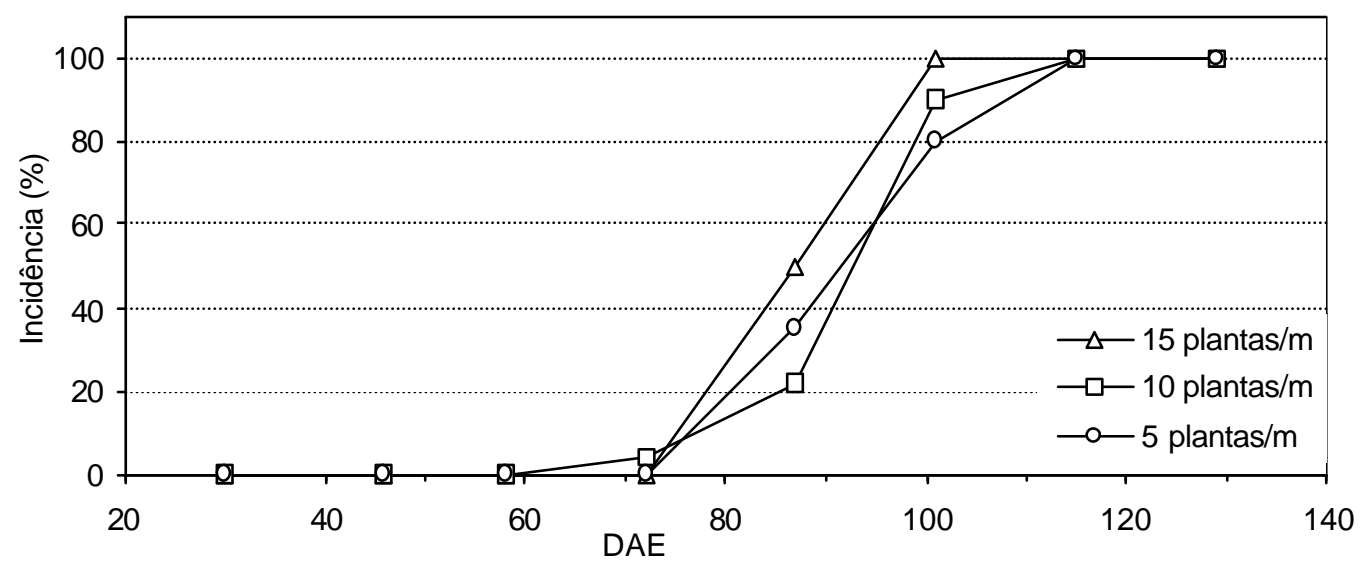

Figura 27 - Incidência de ramulose na cultura do algodoeiro, nas parcelas não inoculadas da cultivar Coodetec 401.

Portanto, fica bastante claro que nos dias que antecederam a avaliação dos 87 DAE, ocorreram condições ambientais extremamente favoráveis à ocorrência de infecção da doença, representada pelo aumento exagerado na sua incidência, tanto nas parcelas da cultivar IAC 23 inoculada aos 30 DAE, como nas parcelas não inoculadas, de ambas as cultivares. A identificação dessas condições será apresentada mais adiante, após a análise dos efeitos das cultivares, das densidades populacionais e da doença, no desenvolvimento e produção do algodoeiro.

\subsection{2 Área abaixo da curva de progresso da doença}

A área abaixo da curva de progresso da doença (AUDPC) estabelece um termo de comparação, simplificado em um único valor, entre cada cultivar e densidade populacional estudadas, como apresentado na Figura 28.

De maneira geral, a AUDPC permitiu identificar os mesmo aspectos já levantados anteriormente, que foram a grande diferença de intensidade da doença entre as duas cultivares - 2,2 vezes maior na cv. Coodetec 401 - e a ausência de diferenças significativas entre as densidades populacionais, embora tenham sido identificadas diferenças relevantes entre os microclimas de cada densidade. 


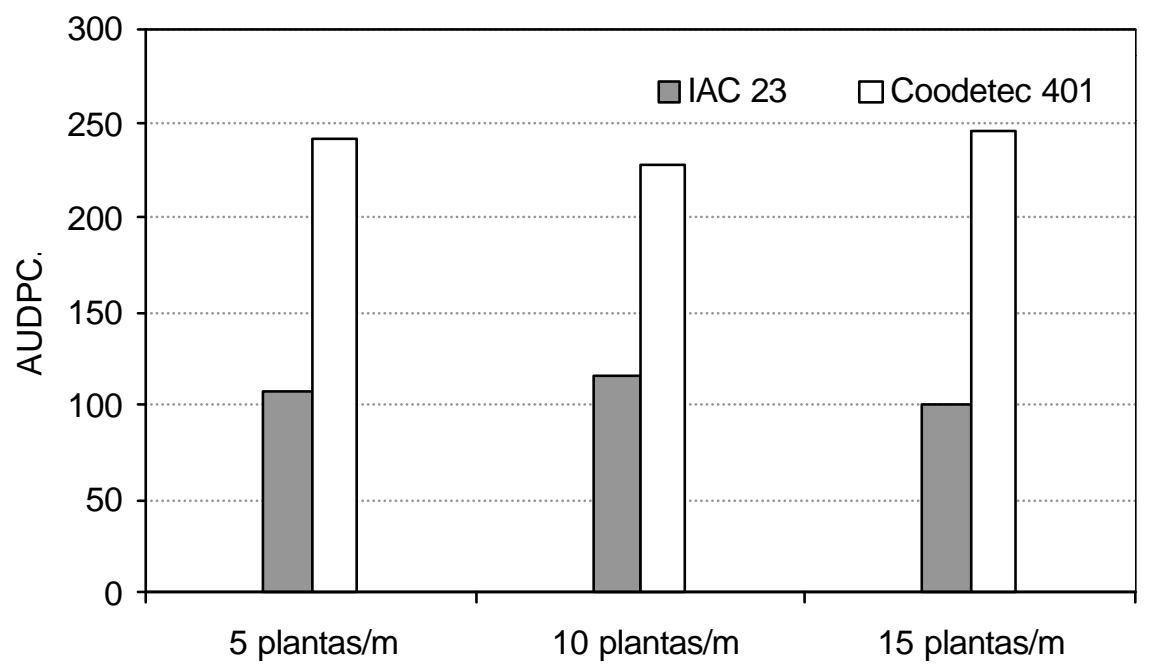

Figura 28 - Área abaixo da curva de progresso da ramulose no algodoeiro, cultivares IAC 23 e Coodetec 401, nas densidades de 5, 10 e 15 plantas por metro, parcelas inoculadas.

Situação semelhante foi descrita por Sentelhas (1992), na qual a intensidade da helmintosporiose do trigo não apresentou diferença entre populações de plantas mais ou menos densas e atribuiu a isso, o fato das condições macroclimáticas terem sido bastante favoráveis ao patógeno. A densidade de plantio só apresentou influência no desenvolvimento das doenças, quando as condições macroclimáticas não foram favoráveis ao desenvolvimento do patógeno. Isso também foi relatado por Rotem \& Palti (1969) que, avaliando o efeito da irrigação no microclima, obtiveram uma influência desprezível em condições de baixa temperatura e alta umidade. Já, em condições extremas de altas temperaturas e baixa umidade, os autores observaram uma redução de 8 a $9^{\circ} \mathrm{C}$ e aumento em $50 \%$ da umidade relativa.

Portanto, embora não tenham sido verificadas diferentes intensidades de ramulose nas diferentes densidades populacionais do algodoeiro neste ciclo de novembro de 2001 a abril de 2002, é perfeitamente possível que isso ocorra em um ano em que as condições macroclimáticas seja marginais à ocorrência desta doença e, neste caso, as condições microclimáticas sejam significativas. 
A AUDPC obtida das parcelas não inoculadas é apresentada na Figura 29. Neste caso, não houve diferenças significativas entre as diferentes densidades e entre as duas cultivares. Este fato, deve estar associada a um conjunto de condições altamente favoráveis à ocorrência de infecção, de modo que, tanto na cultivar resistente como na suscetível, a intensidade da doença foi igual.

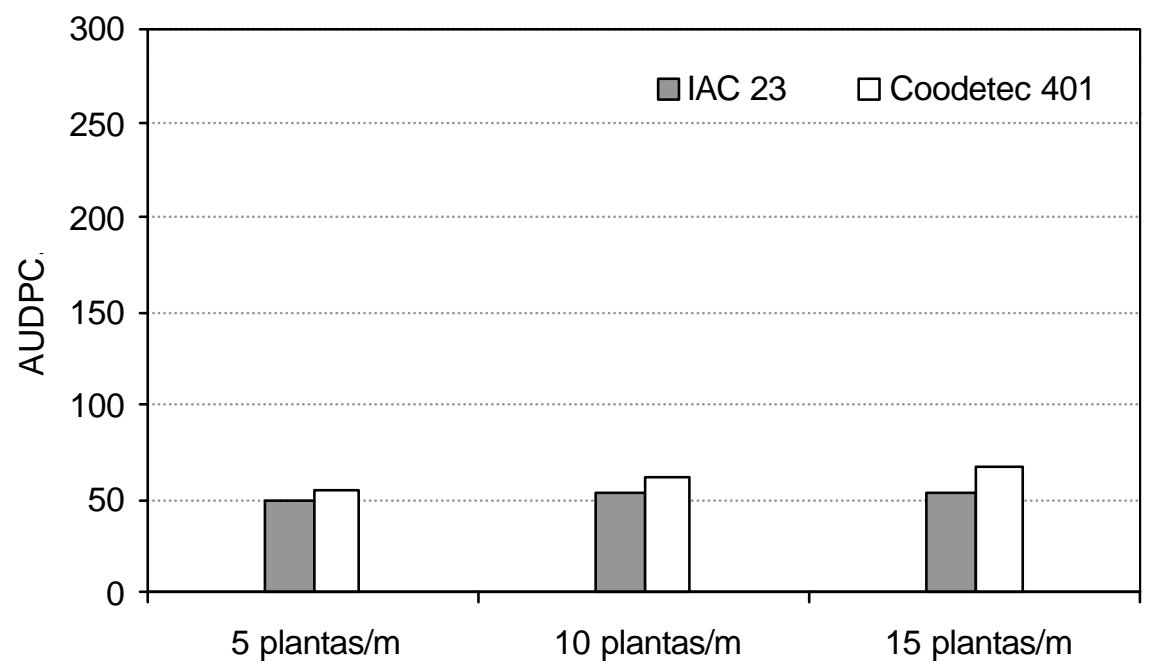

Figura 29 - Área abaixo da curva de progresso da ramulose no algodoeiro, cultivares IAC 23 e Coodetec 401, nas densidades de 5, 10 e 15 plantas por metro, parcelas não inoculadas.

Na Tabela 8 são apresentados os valores de AUDPC e os resultados da análise estatística dos dados das duas cultivares nas três densidades populacionais, nas parcelas inoculadas e não inoculadas. 
Tabela 8. Área sob a curva de progresso da ramulose no algodoeiro, cultivares IAC 23 e Coodetec 401, nas densidades de 5, 10 e 15 plantas por metro, parcelas inoculadas e não inoculadas.

\begin{tabular}{lcccccc}
\hline Cultivar: & & IAC 23 & & \multicolumn{3}{c}{ Coodetec 401} \\
Densidade: & $5 \mathrm{pl} / \mathrm{m}$ & $10 \mathrm{pl} . / \mathrm{m}$ & $15 \mathrm{pl} . / \mathrm{m}$ & $5 \mathrm{pl} . / \mathrm{m}$ & $10 \mathrm{pl} . / \mathrm{m}$ & $15 \mathrm{pl} . / \mathrm{m}$ \\
\hline Parcelas inoculadas & $106 \mathrm{~b}$ & $115 \mathrm{~b}$ & $101 \mathrm{~b}$ & $241 \mathrm{a}$ & $228 \mathrm{a}$ & $246 \mathrm{a}$ \\
Parcelas não inoculadas & 49 & $53 \mathrm{c}$ & 53 & 54 & $61 \mathrm{c}$ & 67
\end{tabular}

* Os valores seguidos pela mesma letra, na linha e na coluna, não diferem estatisticamente, ao nível de 5\% de probabilidade, pelo teste de Tukey. Valores não seguidos por letras não foram analisados estatisticamente.

\subsection{Relações entre o microclima da cultura e intensidade da doença}

Como ilustrado anteriormente, na Figura 22, a incidência da doença nas parcelas inoculadas da cultivar IAC 23, progrediu com incrementos decrescentes, ou seja, apresentou a taxa de crescimento cada vez menor desde a inoculação até a avaliação aos 87 DAE. Nessa fase, a incidência estava praticamente estável, com 37\%, em média, nas três densidades populacionais. Na avaliação seguinte, a incidência média aumentou para $91 \%$.

Nas parcelas não inoculadas da cultivar IAC 23, ocorreu um aumento de incidência ainda maior, de $2 \%$ para $94 \%$ na média das três densidades. Nas parcelas com densidade de 15 plantas por metro, por exemplo, a incidência verificada foi de 0 para $100 \%$ (Figura 26).

Já, na cultivar Coodetec 401, parcelas não inoculadas, o aumento repentino da incidência começou a ocorrer antes do que na cultivar IAC 23. Entre as avaliações do 72 e 87 DAE houve um aumento de 1\% para $36 \%$ e, na seqüência, para 90\% na próxima avaliação, aos 101 DAE (Figura 27).

Isso indica que, na verdade, após um período de grande disseminação da doença, a cultivar Coodetec 401, que é mais suscetível, apresentou sintomas antes que a cultivar IAC 23. Diferentes variedades de uma espécie vegetal podem ser classificadas 
em diferentes níveis de resistência, de acordo com a latência do patógeno em questão. Latência maior indica maior resistência do hospedeiro à colonização. Como consequiência, menor número de ciclos do patógeno serão produzidos sobre aquela variedade particular, e menor deverá ser a quantidade de doença no final da cultura (Amorim, 1995a). Ao que parece, a cultivar IAC 23 apresenta maior resistência à colonização. É provável, portanto, que o período com condições favoráveis à infecção tenha ocorrido entre 72 e 87 DAE, mas que na cultivar IAC 23 só se manifestou após os 87 DAE, na avaliação dos 101 DAE.

No período em questão (72 a 101 DAE), não houve mudança em nenhuma das características da cultura, a não ser o crescimento normal das plantas. Em outras palavras, não houve nenhuma alteração das condições referentes ao patógeno, ao hospedeiro, ou às práticas de manejo que pudessem influenciar a doença. As únicas mudanças relevantes que ocorreram nessa fase foram nas condições meteorológicas.

Entre os elementos meteorológicos que influenciam o desenvolvimento do hospedeiro e patógeno, podem ser citados como principais: umidade do ar, temperatura, precipitação pluvial e vento (Zahler et al., 1991). A observação contínua dessas variáveis, bem como as da cultura e do patógeno são necessários para melhor entendimento e quantificação dessas inter-relações (Sutton et al., 1984).

Assim, a Figura 30a apresenta as curvas de umidade relativa máxima e mínima, DPM e precipitação que ocorreram no período entre 72 e 101 DAE, e a Figura 30 b apresenta as curvas de temperatura máxima e mínima e distância acumulada percorrida pelo vento em quatro dias.

Podemos identificar um conjunto de variáveis meteorológicas em duas combinações distintas, o que define dois períodos característicos (A e B) quanto à possibilidade de ocorrência de doença, como indicados na Figura 30. 
(a)

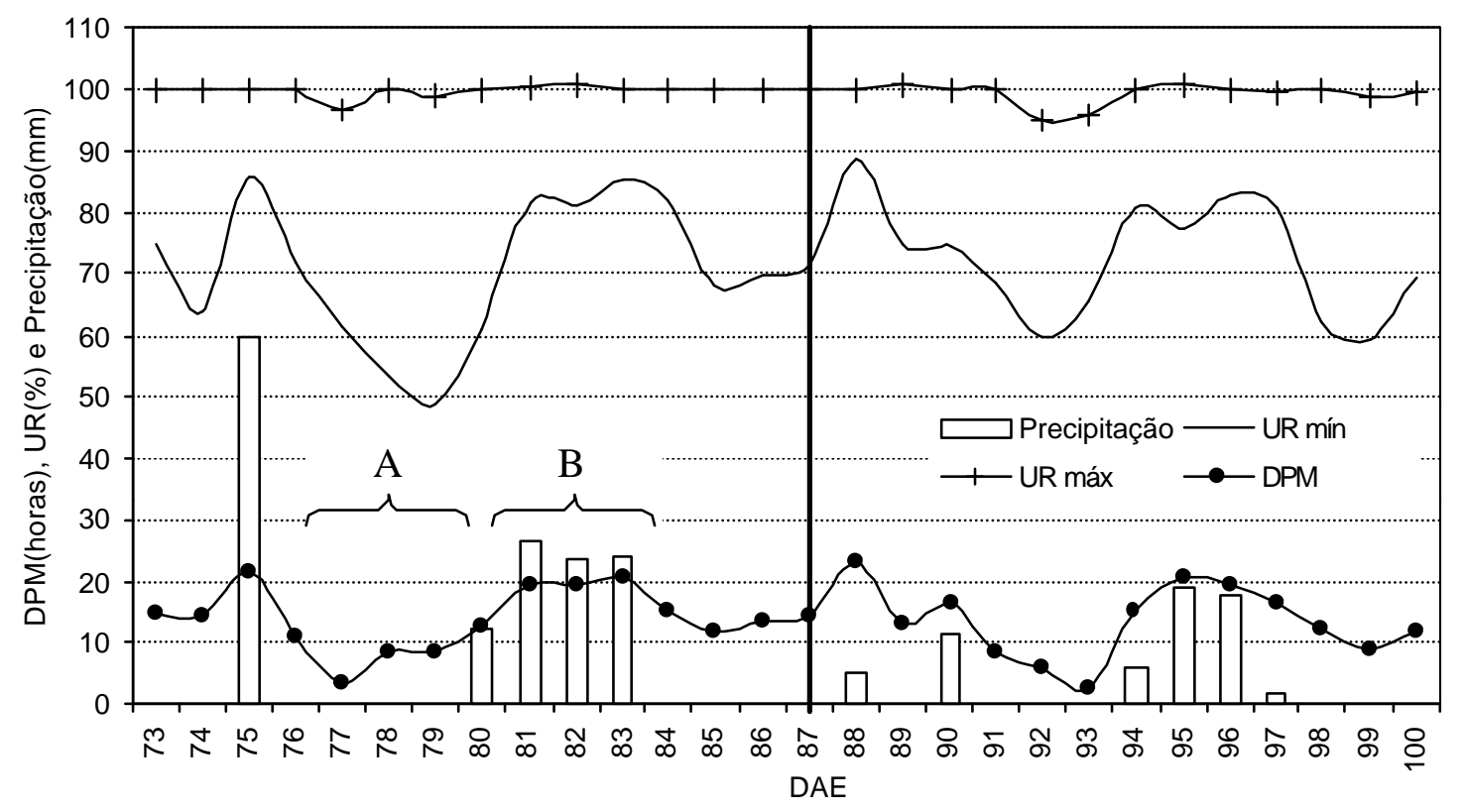

(b)

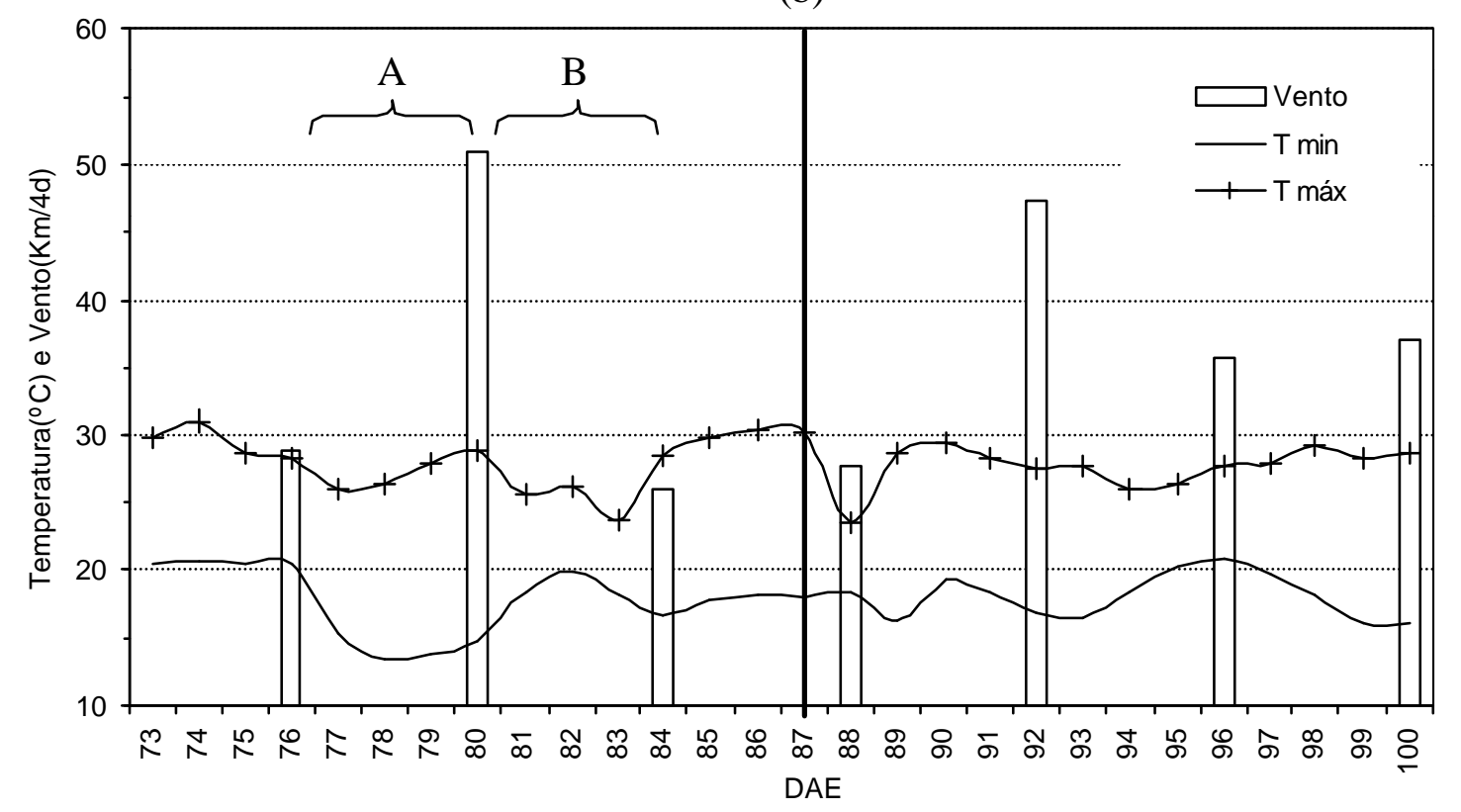

Figura 30 - Variáveis meteorológicas registradas na área experimental nos dias que antecederam o maior aumento de incidência da ramulose no algodoeiro: a) DPM, UR e Precipitação; b) Temperatura e velocidade do vento. 
O período "A" se caracterizou por apresentar, claramente, condições bastante desfavoráveis ao desenvolvimento, não só da ramulose, mas como de doenças fúngicas em geral. Foram quatro dias consecutivos, 77 ao 80 DAE, com grande amplitude térmica, ou seja, temperaturas máximas elevadas e mínimas bastante baixas as menores de todo o ciclo da cultura. Segundo Bedendo (1995), a ocorrência de temperaturas extremas (altas ou baixas) durante o período que antecede a infecção pode alterar a suscetibilidade de plantas às doenças, o que varia de acordo com a espécie do hospedeiro e do patógeno. Por pouco mais de 30 minutos aos 78 e, também aos 79 DAE (dois dias do período "A"), a temperatura se manteve abaixo de $14^{\circ} \mathrm{C}$. Segundo Doorenbos et al. (1979), a semeadura do algodoeiro é aconselhável em regiões ou épocas em que as temperaturas permaneçam entre 18 e $30^{\circ} \mathrm{C}$, nunca ultrapassando o limite inferior de $14^{\circ} \mathrm{C}$.

Ainda no período "A", apesar da umidade relativa máxima sempre ter chegado a $100 \%$ em algum momento do dia, a umidade mínima chegou a valores bastante reduzidos em relação a outras fases, em torno de $60 \%$, porém, chegando a ficar abaixo de 50\%. E, finalmente, em nenhum dos dias de 77 a 79 DAE a DPM foi maior que $8 \mathrm{~h}$, se mantendo, em média, em 6,6 h.

Em seguida, durante o período "B” ocorreram condições muito favoráveis à doença. Foram três dias consecutivos, 81 a 83 DAE, em que se observou pequena amplitude térmica, com máximas mais amenas que em outras fases e mínimas não tão baixas como no período "A". A umidade relativa se manteve sempre bastante elevada, sendo que, até mesmo as mínimas, estiveram sempre acima dos 80\%. A DPM também se manteve elevada, sempre acima de $19,5 \mathrm{~h}$ nas medidas feitas junto às plantas. $\mathrm{O}$ principal fator que acarretou as mudanças de "A" para "B" foram as chuvas que ocorreram no período. Segundo Eversmeyer \& Burleigh (1979), as chuvas têm importância elevada no processo de epidemias de plantas porque dispersam o inóculo, reduzem a luminosidade e provocam quedas de temperatura, aumentando a probabilidade de formação de orvalho por dias seguidos.

Arndt (1944) verificou que a temperatura ótima para infecção da ramulose no campo é de aproximadamente $22^{\circ} \mathrm{C}$ e que a temperatura ótima para o 
desenvolvimento do patógeno está entre $25^{\circ} \mathrm{C}$ e $30^{\circ} \mathrm{C}$. A temperatura média dos dias que corresponderam ao período " $\mathrm{B}$ " variou entre $21^{\circ} \mathrm{C}$ e $22^{\circ} \mathrm{C}$ e entre $22^{\circ} \mathrm{C}$ e $24^{\circ} \mathrm{C}$, nos três dias seguintes ao referido período, ou seja, muito semelhantes às ótimas. O mesmo autor não observou infecção sob temperaturas inferiores a $18^{\circ} \mathrm{C}$ e superiores a $36^{\circ} \mathrm{C}$. Embora a temperatura média tenha se mantido acima do limite mínimo durante o período "A", por cerca de gh em média a temperatura chegou a valores inferiores a $18^{\circ} \mathrm{C}$, de modo que a temperatura no período "A" atuou induzindo um aumento da predisposição do hospedeiro e não favorecendo a infecção, o que ocorreu no período "B”.

Santos (1993) associou o maior aumento da doença, observado aos 81 DAE, à ocorrência de, no mesmo período, valores elevados de umidade relativa e temperaturas mínimas maiores que $18^{\circ} \mathrm{C}$. Além disso, o autor apresenta dados de maior ocorrência de chuvas nas duas semanas que antecederam o maior aumento da doença. $\mathrm{O}$ mesmo autor afirma que não houve aumento da incidência da doença aos 123 DAE, época em que as chuvas cessaram e a temperatura mínima atingiu valores como $12,8^{\circ} \mathrm{C}$. A influência da precipitação e da umidade relativa sobre a ramulose também foi destacada por outros autores (Kimati, 1980; Lima et al., 1985).

É possível, então, associar o aumento significativo de incidência da ramulose - de maneira generalizada em todos os tratamentos do experimento, inoculados e não inoculados - às condições meteorológicas ocorridas no período "B" que, como verificado, propiciaram condições ótimas para a ocorrência de infecção pelo patógeno ou, ainda, ao período "A", que foram responsáveis pela predisposição do hospedeiro ao ataque do patógeno (Hayman, 1969; Doorenbos et al., 1979; Tanaka, 1995; Bedendo, 1995) ou, ainda mais provável, a interação de ambos.

É possível ainda, que a ocorrência de condições desfavoráveis ao patógeno, como as altas temperaturas diurnas associada à baixa umidade relativa e à baixa temperatura noturna (período “A”), induza a reação do fungo à adversidade do ambiente, provocando a liberação de estruturas de reprodução como forma de sobrevivência da espécie. No entanto, um exame mais atento do problema, principalmente sob o aspecto da sobrevivência, demonstra que os mecanismos reprodutivos dos patógenos em função das condições do ambiente não são tão simples 
assim (Bergamin Filho \& Amorim, 1996), não havendo unanimidade entre os diversos autores sobre o assunto, devido, principalmente, à grande variabilidade de espécies e condições ambientais.

De acordo com Amorim (1995b), a produção de inóculo é bastante variável para cada espécie patogênica particular. Patógenos de regiões quentes (clima tropical e subtropical), apresentam curvas de produção diária de esporos com vários picos de máxima esporulação distribuídos por todo o período infeccioso. Segundo Cohen \& Rotem (1988), a formação de estruturas reprodutivas em fungos fitopatogênicos requer uma série de condições específicas de ambiente. Para uma determinada espécie fúngica, a gama de condições ambientais requerida para a esporulação é freqüentemente mais restrita que aquela requeria para a infecção. Para Amorim (1995a), altos níveis de esporulação, na natureza, servem para vencer barreiras impostas à infecção, como ambiente desfavorável e hospedeiro resistente, possibilitando a sobrevivência do patógeno e acarretando, eventualmente, severas epidemias.

Nesse contexto, é válido mencionar que, como demonstrado na Figura $30 \mathrm{~b}$, os ventos ocorridos no período "A" foram muito mais intensos do que o do restante do tempo. Embora a velocidade média dos ventos no interior de uma plantação represente apenas uma fração da velocidade média observada acima das plantas, rajadas muito rápidas são frequientes ao nível das folhas. As barreiras impostas à liberação dos esporos, representadas pelas camadas estacionárias de ar, são, deste modo, temporariamente removidas pelo vento que promove, ao mesmo tempo, a liberação e o transporte do patógeno (Amorim, 1995b). Dessa forma, os ventos mais intensos do período "A" facilitaram a dispersão de esporos, principalmente para as parcelas não inoculadas, onde a incidência passou de 0 para $100 \%$ em alguns casos, após a seqüência de "A" para "B".

Sabe-se que Colletotrichum gossypii var. cephalosporioides produz conídios tanto em conidióforos presentes na matriz gelatinosa do acérvulo, como também em setas férteis. Este fato tem uma grande importância do ponto de vista epidemiológico. O primeiro tipo de conídio só é disperso por respingos de chuvas, 
enquanto os conídios produzidos pelas setas férteis são rapidamente deslocados pelo movimento do ar e poderão alcançar maiores distâncias (Lenné et al., 1984).

A liberação por respingos é particularmente importante para propágulos retidos em superfícies mucilaginosas, como a matriz do acérvulo. Esta mucilagem composta de açúcares e proteínas, serve para proteger esporos e bactérias da dessecação. $\mathrm{Na}$ presença de água, entretanto, ela é dissolvida deixando livre a suspensão de propágulos na superfície do hospedeiro (Bedendo, 1995). Patógenos que produzem este tipo de substância mucilaginosa, como muitas bactérias e fungos do gênero Colletotrichum, têm, de fato, nos respingos de chuva seu principal agente de liberação (Amorim, 1995b).

Dessa forma, há a tendência de a ramulose disseminar-se em áreas circulares ou elípticas, como conseqüência da dispersão pela chuva dos conídios da matriz gelatinosa, mas também com o aparecimento simultâneo de novos focos, como conseqüência da dispersão pelo vento dos conídios produzidos nas setas férteis (Drummond, 1961). Conceito semelhante, apresentou Abrahão (1961) que, em observações de campo, verificou que a disseminação da doença em condições normais, inicia-se a partir de reduzido número de plantas, às vezes, uma ou duas que funcionam como centro de irradiação, não só para plantas vizinhas mas, também, para outras mais distantes.

Nesse sentido, com já mencionado por Cia \& Salgado (1995), a principal medida de controle para a ramulose é a utilização de cultivares que apresentem resistência ao patógeno, como a IAC 23, por exemplo, que, no presente trabalho, se mostrou bem menos suscetível que a cultivar Coodetec 401. No entanto, o mesmo autor acrescenta que nem sempre a utilização de cultivares resistentes é possível, por razões técnicas ou econômicas diversas. Nesses casos, segundo Paiva et al. (2001), outra medida que pode ser adotada é o controle químico com fungicidas, os quais devem ser aplicados quando a doença se encontra na fase inicial de manchas necróticas. O controle químico não se mostra efetivo quando a doença encontra-se na fase de indução de superbrotamento. 
Diante dos resultados apresentados na análise do microclima da cultura do algodoeiro, o monitoramento agrometeorológico se apresenta como uma ferramenta extremamente útil e eficiente na identificação de momentos ou fases em que se faz mais necessária a aplicação de fungicidas, antes mesmo da manifestação dos sintomas, que podem ocorrer dias depois dos momentos de infecção mais intensa.

\subsection{Relações entre intensidade da doença e cre scimento da cultura}

\subsubsection{Massa seca e altura das plantas}

A Figura 31 ilustra a massa seca das plantas nas parcelas que receberam a inoculação com o fungo e as que não receberam $(\mathrm{T})$, o que, neste caso, permite a comparação do crescimento e do acúmulo de massa seca entre as plantas sadias e as doentes.

O que se pode observar é que a cultivar IAC 23 praticamente não teve seu crescimento afetado pela doença. Além disso, não foi possível verificar efeito diferenciado da doença conforme a densidade populacional. Em média, a redução de massa seca nas parcelas doentes, em relação às sadias, foi de 1,8\% aos 90 DAE e, de $4,1 \%$ aos 150 DAE. 

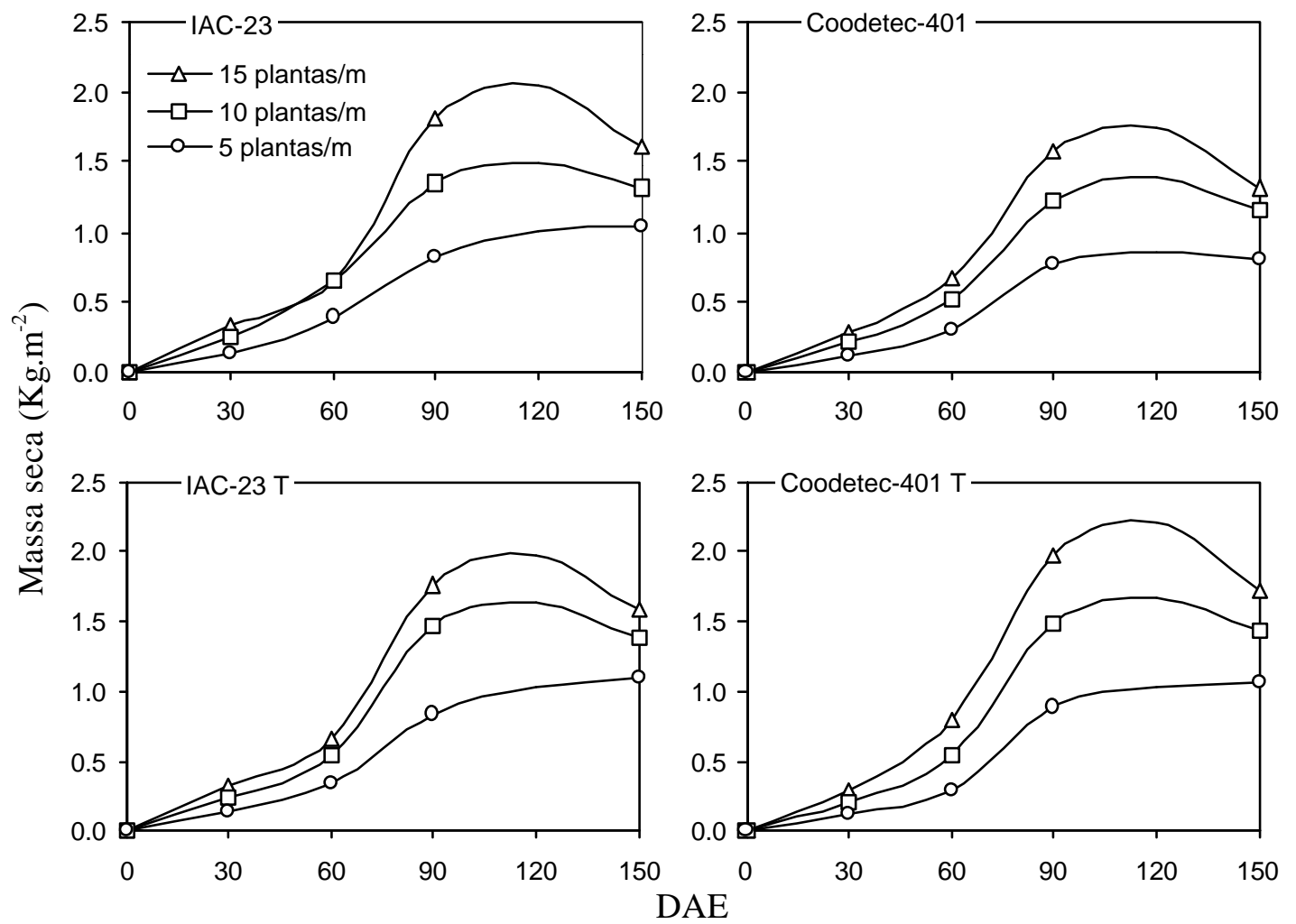

Figura 31 - Massa seca da cultura do algodoeiro, cultivares IAC 23 e Coodetec 401, nos tratamentos inoculados e testemunhas $(\mathrm{T})$ - não inoculados; de 0 a 150 dias após emergência (DAE), nas densidades de 5, 10 e 15 plantas por metro.

Na cultivar mais suscetível à doença, Coodetec 401, pode-se dizer que a doença afetou mais a densidades de 5 e 15 plantas por metro. Aos 90 DAE, a redução de massa seca na densidade de 10 plantas por metro foi de $15 \%$ e aproximadamente, $20 \%$ nas outras duas densidades populacionais, em relação às plantas não inoculadas. Aos 150 DAE, a redução de massa seca na densidade de 10 plantas por metro foi de $23 \%$ e, aproximadamente, $30 \%$ nas outras duas densidades (Tabela 9). 
Tabela 9. Massa seca por parcela de algodoeiro, das cultivares IAC 23 e Coodetec 401 aos 90 DAE, nas densidades de 5, 10 e 15 plantas por metro, parcelas inoculadas e não inoculadas.

\begin{tabular}{lcccccc}
\hline Cultivar: & & IAC 23 & & \multicolumn{3}{c}{ Coodetec 401} \\
Densidade: & $5 \mathrm{pl} / \mathrm{m}$ & $10 \mathrm{pl} . / \mathrm{m}$ & $15 \mathrm{pl} . / \mathrm{m}$ & $5 \mathrm{pl} . / \mathrm{m}$ & $10 \mathrm{pl} . / \mathrm{m}$ & $15 \mathrm{pl} . / \mathrm{m}$ \\
\hline Parcelas inoculadas & $7,6 \mathrm{~cd}$ & $12,1 \mathrm{ab}$ & $16,3 \mathrm{a}$ & $6,9 \mathrm{~d}$ & $11,1 \mathrm{bc}$ & $14,1 \mathrm{ab}$ \\
Parcelas não inoculadas & 7,6 & $13,2 \mathrm{ab}$ & 15,8 & 8,4 & $13,1 \mathrm{ab}$ & 17,8
\end{tabular}

* Os valores seguidos pela mesma letra, na linha e na coluna, não diferem estatisticamente, ao nível de 5\% de probabilidade, pelo teste de Tukey. Valores não seguidos por letras não foram analisados estatisticamente.

A altura das plantas não foi afetada pela ramulose na cultivar IAC 23. Como conseqüência da maior intensidade da doença na cultivar Coodetec 401, inclusive com superbrotamento mais evidente, a altura média das plantas verificada nas parcelas inoculadas desta cultivar foi menor do que nas não inoculadas (Tabela 10).

Tabela 10. Altura média das plantas de algodoeiro, cultivares IAC 23 e Coodetec 401, inoculadas e não inoculadas.

\begin{tabular}{|c|c|c|}
\hline Cultivar: & IAC 23 & Coodetec 401 \\
\hline Densidade: & Média das 3 densidades & Médias das 3 densidades \\
\hline Parcelas inoculadas & $118 \mathrm{a}$ & $98 \mathrm{c}$ \\
\hline Parcelas não inoculadas & $118 \mathrm{a}$ & $110 \mathrm{~b}$ \\
\hline
\end{tabular}

Não foi possível identificar relações com bom grau de correlação entre os dados de intensidade da doença ou AUDPC e os valores de massa seca das plantas de algodoeiro, como apresentado na Figura 32, tão pouco com os dados de altura das plantas. 

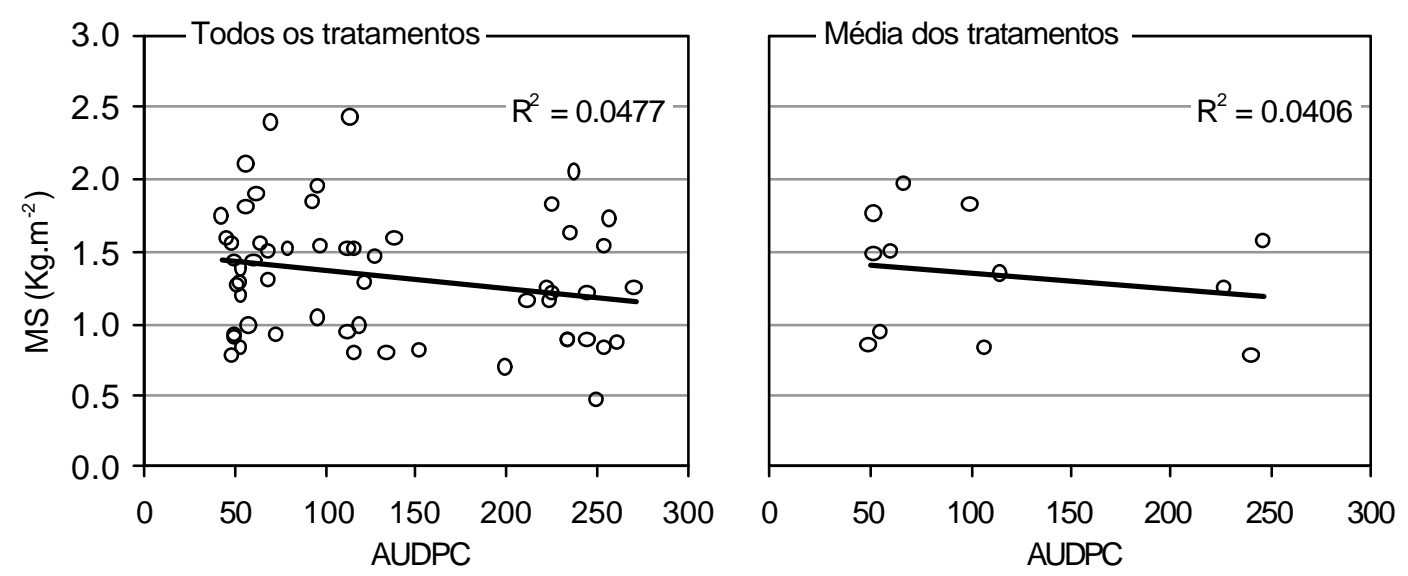

Figura 32 - Relação entre a área sob a curva de progresso da doença (AUDPC) e a massa seca (MS) aos 95 DAE, em todos os tratamentos e na média deles. Coeficientes de correlação não significativos para á = 0,05.

\subsection{2 Área foliar}

A Figura 33 apresenta o índice de área foliar (IAF) nas parcelas inoculadas e não inoculadas (T) com o patógeno. As curvas do IAF da cultivar IAC 23 praticamente não se alteraram nas parcelas inoculadas em relação às não inoculadas com o patógeno. Por outro lado, na cultivar Coodetec 401, verifica-se um menor desenvolvimento da área foliar e, conseqüentemente, do IAF nas parcelas inoculadas, onde ocorreu a ramulose. 

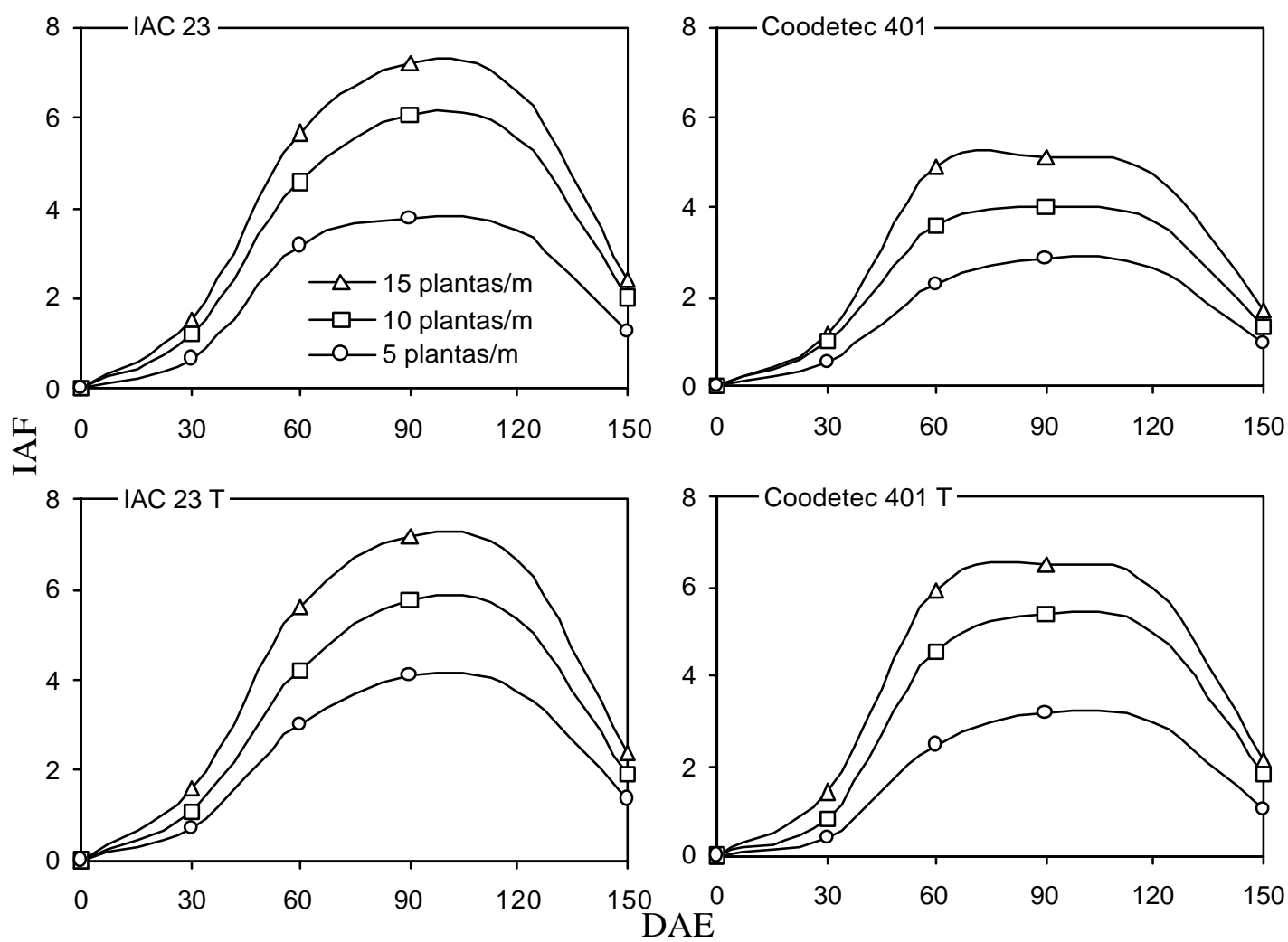

Figura 33 - Área foliar ao longo do ciclo da cultura do algodoeiro, cultivares IAC 23 e Coodetec 401, inoculadas e testemunhas (T) não inoculadas, nas densidades de 5,10 e 15 plantas por metro.

A identificação das diferenças quanto ao IAF ficam mais fáceis de serem constatadas por meio da duração da área foliar (DAF), ou seja, a integral da área foliar de 0 a 150 DAE, apresentada na Figura 34. 

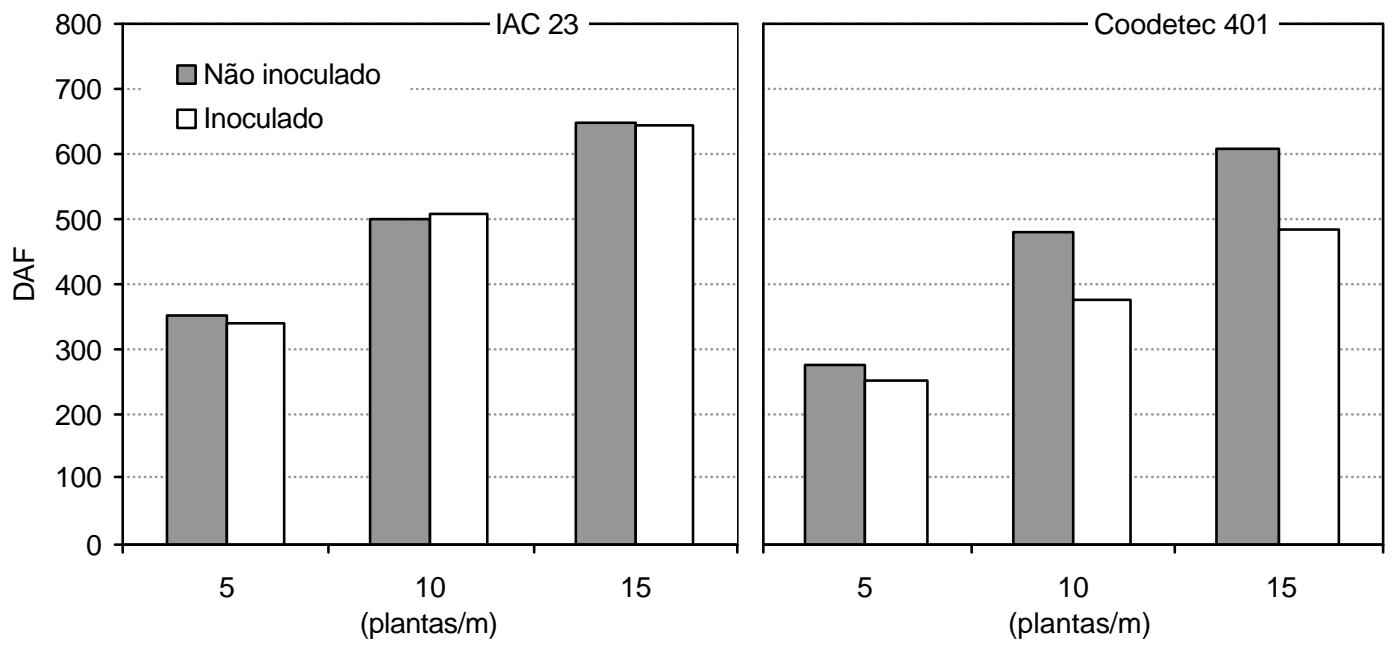

Figura 34 - Duração da área foliar (DAF) da cultura do algodoeiro, cultivares IAC 23 e Coodetec 401, inoculadas e não inoculadas, nas densidades de 5, 10 e 15 plantas por metro.

Praticamente não ocorreu diferença entre os tratamentos inoculados e não inoculados da cultivar IAC 23. Na cultivar Coodetec a redução verificada de DAF, foi de $8,5 \%$ na densidade de 5 plantas por metro, de $22 \%$ na densidade de 10 plantas por metro, e de $20 \%$ na densidade de 15 plantas por metro.

Não foi possível identificar relações com bom grau de correlação entre os dados de intensidade da doença ou AUDPC e os valores de IAF das plantas de algodoeiro (Resultados não apresentados). 


\subsection{Relações entre intensidade da doença e a produção da cultura}

A Figura 35 ilustra o rendimento de algodão em caroço, obtido das cultivares IAC 23 e Coodetec 401, nas parcelas inoculadas e não inoculadas pelo patógeno, com densidades populacionais de 5, 10 e 15 plantas por metro.

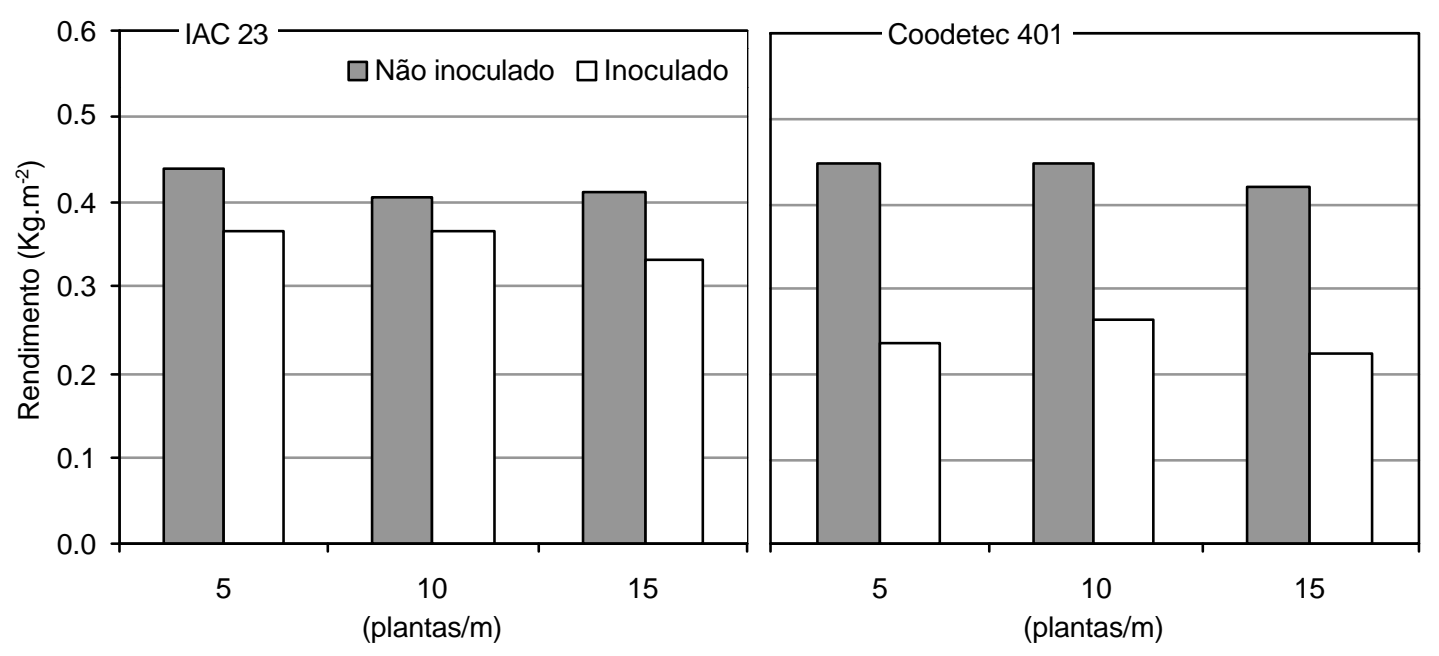

Figura 35 - Rendimento de algodão em caroço, das cultivares IAC 23 e Coodetec 401, nas parcelas inoculadas e não inoculadas, nas densidades de 5, 10 e 15 plantas por metro.

Nas parcelas não inoculadas, o rendimento médio nas três densidades populacionais foi de $0,42 \mathrm{Kg} \cdot \mathrm{m}^{-2}$ de algodão em caroço na cultivar IAC 23 e de $0,44 \mathrm{Kg} \cdot \mathrm{m}^{-2}$ na cultivar Coodetec 401. Já nas parcelas inoculadas, o rendimento médio das três densidades populacionais foi de $0,36 \mathrm{Kg} \cdot \mathrm{m}^{-2}$ de algodão em caroço na cultivar IAC 23, e de 0,24Kg. $\mathrm{m}^{-2}$ na cultivar Coodetec 401 (Tabela 11).

Nas parcelas não inoculadas, como se pode observar, praticamente não houve diferença quanto ao rendimento entre as densidades populacionais. Como exposto por Staut \& Lamas (1999), os resultados de pesquisas desenvolvidas com o algodoeiro, nas mais diferentes regiões, tanto no exterior como no Brasil, não são consistentes no que se refere a melhor população de plantas, por ser o algodoeiro uma espécie com boa plasticidade morfológica, quando se analisa apenas o aspecto quantitativo da produção. 
Tabela 11. Rendimento de algodão em caroço, em Kg.m ${ }^{-2}$, das cultivares IAC 23 e Coodetec 401, nas densidades de 5, 10 e 15 plantas por metro, nas parcelas inoculadas e não inoculadas.

\begin{tabular}{lcccccc}
\hline Cultivar & \multicolumn{3}{c}{ IAC 23 } & \multicolumn{3}{c}{ Coodetec 401} \\
Densidade & $5 \mathrm{pl} / \mathrm{m}$ & $10 \mathrm{pl} . / \mathrm{m}$ & $15 \mathrm{pl} . / \mathrm{m}$ & $5 \mathrm{pl} . / \mathrm{m}$ & $10 \mathrm{pl} / \mathrm{m}$ & $15 \mathrm{pl} . / \mathrm{m}$ \\
\hline Parcelas inoculadas & $0,37 \mathrm{ab}$ & $0,37 \mathrm{ab}$ & $0,33 \mathrm{bc}$ & $0,24 \mathrm{~d}$ & $0,26 \mathrm{~cd}$ & $0,22 \mathrm{~d}$ \\
Parcelas não inoculadas & 0,44 & $0,40 \mathrm{ab}$ & 0,41 & 0,45 & $0,45 \mathrm{a}$ & 0,42 \\
\hline $\begin{array}{l}* \\
\text { Oes valores seguidos pela mesma letra, na linha e na coluna, não diferem estatisticamente, ao nível de 5\% }\end{array}$ \\
$\begin{array}{l}\text { de probabilidade, pelo teste de Tukey. Valores não seguidos } \\
\text { estatisticamente. }\end{array}$
\end{tabular}

A Figura 36 apresenta as análises de regressão entre a área abaixo da curva de progresso da doença (AUDPC) e o rendimento de algodão em caroço, considerando-se todos os tratamentos separadamente e a média deles. As duas análises resultaram em bons coeficientes de correlação com significância estatística verificada por meio de teste $\mathrm{F}$, para á $=0,05$ e, permitem visualizar com clareza que quanto maior a AUDPC menor o rendimento do algodoeiro. Obteve-se um melhor ajuste da reta na relação feita com as médias dos tratamentos, conseqüentemente, com maior coeficiente de determinação. 

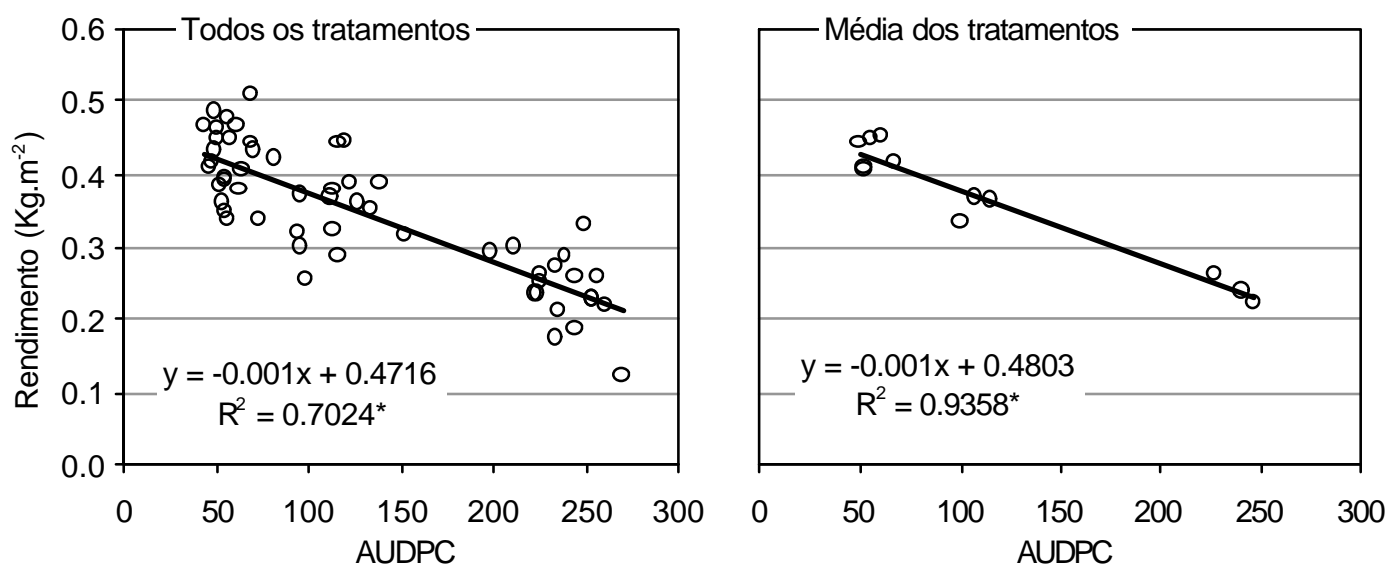

Figura 36 - Relação entre a área sob a curva de progresso da ramulose (AUDPC) e o rendimento de algodão em caroço, em todos os tratamentos e na média deles. Coeficientes de correlação significativos para á =0,05.

O estabelecimento da relação entre intensidade da ramulose - neste caso, expresso na forma de AUDPC - e dano, ou seja, perda de rendimento, é fundamental para a tomada de decisão a respeito do uso ou não do controle. Obviamente, a decisão será baseada no custo. Em outras palavras, o controle deverá ser realizado quando a intensidade da doença for tal que o dano futuro decorrente - estimado através da relação estabelecida - provoque perda maior que o valor do custo de controle.

A redução no rendimento de algodão em caroço, das parcelas inoculadas em relação às não inoculadas, é apresentada na Figura 37. Além da evidente diferença entre as duas cultivares, é possível identificar que, a redução no rendimento foi menor na densidade populacional de 10 plantas por metro nas duas cultivares. 


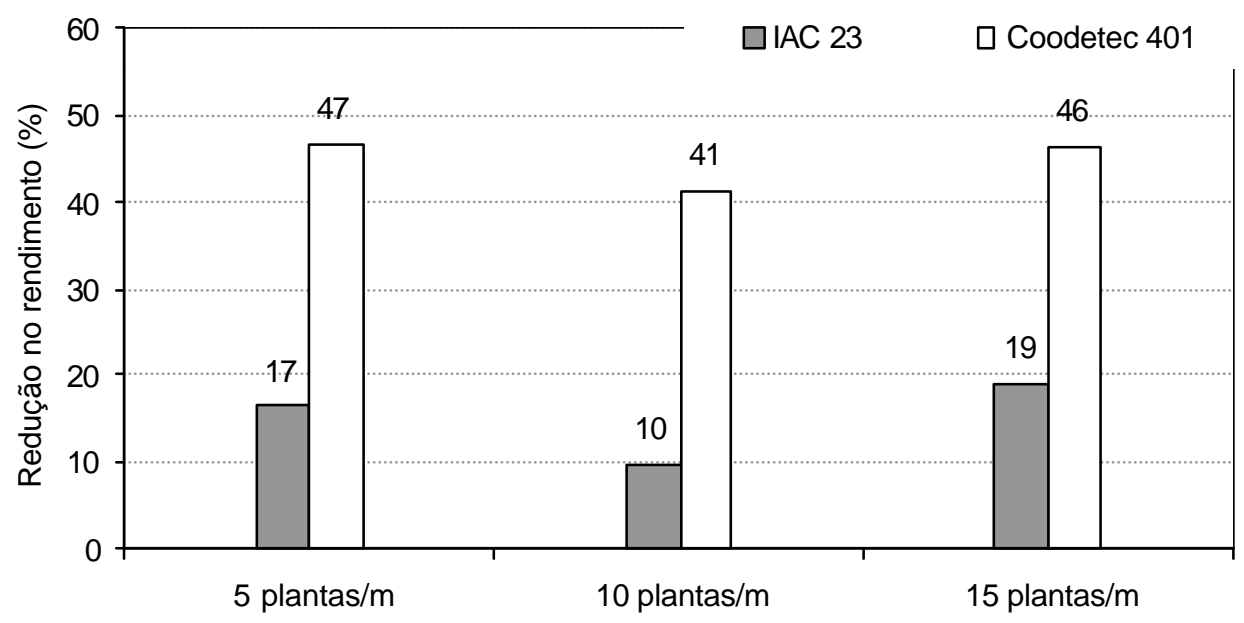

Figura 37 - Redução percentual no rendimento de algodão em caroço, das cultivares IAC 23 e Coodetec 401, nas densidades de 5, 10 e 15 plantas por metro; parcelas inoculadas em relação às não inoculadas.

O índice de colheita foi maior quanto menor a densidade populacional, e foram bastante similares nas duas cultivares. A ocorrência da doença reduziu os índices proporcionalmente em todas as densidades populacionais e nas duas cultivares mas, em maior intensidade, na cultivar Coodetec 401 (Tabela 12).

Tabela 12. Índice de colheita da cultura do algodoeiro, cultivares IAC 23 e Coodetec 401, nas densidades de 5, 10 e 15 plantas por metro, nas parcelas inoculadas e não inoculadas.

\begin{tabular}{lcccccc}
\hline Cultivar: & \multicolumn{3}{c}{ IAC 23} & \multicolumn{3}{c}{ Coodetec 401} \\
Densidade: & $5 \mathrm{pl} . / \mathrm{m}$ & $10 \mathrm{pl} . / \mathrm{m}$ & $15 \mathrm{pl} . / \mathrm{m}$ & $5 \mathrm{pl} . / \mathrm{m}$ & $10 \mathrm{pl} . / \mathrm{m}$ & $15 \mathrm{pl} . / \mathrm{m}$ \\
\hline Parcelas inoculadas & $0,40 \mathrm{a}$ & $0,31 \mathrm{abc}$ & $0,23 \mathrm{~cd}$ & $0,34 \mathrm{ab}$ & $0,25 \mathrm{bcd}$ & $0,18 \mathrm{~d}$ \\
Parcelas não inoculadas & 0,47 & $0,32 \mathrm{abc}$ & 0,30 & 0,50 & $0,35 \mathrm{ab}$ & 0,27 \\
\hline
\end{tabular}

* Os valores seguidos pela mesma letra, na linha e na coluna, não diferem estatisticamente, ao nível de 5\% de probabilidade, pelo teste de Tukey. Valores não seguidos por letras não foram analisados estatisticamente. 
A redução no rendimento da cultura e, também, no índice de colheita, tem como principal causa o fato do fungo afetar o meristema apical provocando sua necrose, o que estimula o desenvolvimento dos brotos laterais que se transformam em "ramos extranumerários", conferindo a planta um aspecto de superbrotamento ou envassouramento, como descrito por Paiva et al., (2001). Além disso, segundo Cia \& Salgado (1995), quando a doença afeta plantas novas, as gemas terminais dos ramos extranumerários podem sofrer novas infecções e, pela sua morte, estimulam o desenvolvimento de novas gemas. Esse carrear de energias para o crescimento vegetativo em resposta a sucessiva destruição das gemas apicais, exaure completamente a planta para a finalidade de frutificação. 


\section{CONCLUSÕES}

Os resultados apresentados neste estudo permitiram concluir que:

1. As densidades populacionais da cultura do algodoeiro, de 5, 10 e 15 plantas por metro, não afetaram a altura das plantas.

2. Nas densidades de 10 e 15 plantas por metro, entre 95 e 150 DAE, a massa seca das plantas diminuiu, enquanto que na densidade de 5 plantas por metro, a massa seca aumentou.

3. Quanto maior a densidade populacional da cultura do algodoeiro, menor é o índice de colheita.

4. As densidades de 5,10 e 15 plantas por metro na cultura do algodoeiro, não afetaram a temperatura da foliosfera, na altura do terço superior da plantas.

5. As temperaturas médias ao longo do ciclo da cultura do algodoeiro, apresentam diferenças significativas entre as medidas no terço superior da cultura e na estação meteorológica padrão, a $2 \mathrm{~m}$ de altura.

6. A umidade relativa do ar foi significativamente afetada pela densidade populacional da cultura do algodoeiro, tendo maior efeito até os 45 dias após emergência.

7. A diferença de umidade relativa do ar foi maior entre a estação meteorológica padrão e a foliosfera da cultura do algodoeiro, do que entre a foliosfera das diferentes densidades populacionais. 
8. O adensamento da cultura do algodoeiro teve grande efeito no aumento da duração do período de molhamento na foliosfera e, assim como na umidade relativa, esta diferença entre densidades é maior na fase inicial da cultura, diminuindo progressivamente à medida que a cultura se desenvolve.

9. Na cultura do algodoeiro, a densidade de 15 plantas por metro na linha de plantio, gerou condições mais favoráveis ao desenvolvimento da ramulose do que a densidade de 10 plantas por metro que, por sua vez, mais que a de 5 plantas por metro.

10. Devido às condições macroclimáticas durante o período do experimento terem sido muito favoráveis ao desenvolvimento da ramulose, as diferenças microclimáticas proporcionadas pelas diferentes densidades populacionais não afetaram a intensidade da doença.

11. Períodos com temperatura do ar muito baixa, aumentaram marcadamente a predisposição do algodoeiro à ocorrência de ramulose.

12. A manifestação dos sintomas, expressos pela área abaixo da curva de progresso da doença foi, 2,2 vezes maior na cultivar Coodetec 401 em relação à cultivar IAC 23.

13. A cultivar IAC 23 apresentou maior resistência à ramulose do que a Coodetec 401, tanto na fase de infecção como, na fase de colonização pelo patógeno.

14. A ocorrência de ramulose na cultura do algodoeiro reduziu a altura média, a massa seca e o índice de área foliar da cultivar Coodetec 401, e não afetou essas variáveis na cultivar IAC 23.

15. Na cultivar Coodetec 401, a redução na duração da área foliar provocada pela ramulose, foi menor na densidade de 5 que nas de 10 e 15 plantas por metro, e não houve efeito na cultivar IAC 23.

16. Não foi verificada correlação significativa entre duração de área foliar e rendimento de algodão em caroço, nas duas cultivares, inoculadas ou não. 
17. Nas duas cultivares, a redução de rendimento provocada pela doença foi menor na densidade populacional de 10 plantas por metro, do que nas demais, que foram semelhantes.

18. A área sob a curva de progresso da ramulose no algodoeiro, apresentou elevada correlação com a perda de rendimento de algodão em caroço, sendo esta, uma boa variável para a estimativa dos danos causados pela doença. 


\section{REFERÊNCIAS BIBLIOGRAFICAS}

ABRAHÃO, J. Controle da ramulose tardia do algodoeiro. O Biológico, v. 27, n. 6, p. 121-123, 1961.

AGRIOS, G.N. Environmental effects on disease development. In: Agrios, G.N. (Ed.) Plant pathology. New York: Academic Press, 1997. p. 143-172.

ALLEN, S.J.; BROWN, J.F.; KOCHMAN, J.K. Effect of temperature, dew period, and light on the growth and development of Alternaria helianthi. Phytopathology, v. 73, p. 793-796, 1982.

AMORIM, L. Colonização e reprodução. In: BERGAMIN FILHO, A.; KIMATI, H.; AMORIN, A. Manual de Fitopatologia. 3 ed. São Paulo: Agronômica Ceres, 1995a. V.1. p. 309-324.

AMORIM, L. Disseminação. In: BERGAMIN FILHO, A.; KIMATI, H.; AMORIN, A. Manual de Fitopatologia. 3 ed. São Paulo: Agronômica Ceres, 1995b. V.1. p. 267294.

AMORIN NETO, M. S.; BELTRÃO, N.E. M. Zoneamento do algodão herbáceo no Nordeste. In: BELTRÃO, N.E. M. (Org.). O agronegócio do algodão no Brasil. Brasília: Embrapa Comunicação para Transferência de Tecnologia, 1999. p. 211-229.

ARAGNO, M. Responses of microorganisms to temperature. In: LANGE, O.L.; NOBEL, P.S.; OSMOND, C.B.; ZIEGLER, H. Physiological plant ecology: responses to the physical environment. New York: Heidelberg, 1981. p. 339-369.

ARNDT, C.H. Infection of cotton seedlings by Colletotrichum gossypii as affected by temperature. Phytopathology, v. 34, p. 861 - 869, 1944.

AZEVÊDO, D.M.P. de; BELTRÃO, N.E. M.; NÓBREGA, L.B. da; SANTOS, J.W. dos; VIEIRA, D.J. Período crítico de competição entre plantas daninhas e o algodoeiro anual irrigado. Pesquisa Agropecuária Brasileira, v. 29, n. 9, p. 14171425, set. 1994. 
BAKER, D.N.; HESKETH, J.D.; DUNCAN, W.G. Simulation of growth and yield in cotton. I. Gross photosynthesis, respiration and growth. Crop Science, v. 12, n. 4, p. 431-435, July/Aug. 1972.

BASHI, E.; ROTEM, J. Adaptation of four pathogens to semi-arid habitats as conditioned by penetration rate and germinating spore survival, Phytopathology, v. 64, p. 1035-1039, 1974.

BEDENDO, I.P. Ambiente e Doença. In: BERGAMIN FILHO, A.; KIMATI, H.; AMORIN, A. Manual de fitopatologia. $3^{\text {a }}$ ed. São Paulo: Agronômica Ceres, 1995. v.1, p. 331-341.

BEDNARZ, C.W.; BRIDGES, D.C.; BROWN, S.M. Analysis of cotton yield stability across population densities. Agronomy Journal, v. 92, n. 1, p. 128-135, Jan. 2000.

BELLETINI, S. Comportamento do algodão IAC 20 (Gossypium hirsutum L. raça latifolium) em diferentes espaçamentos e distribuições espaciais. Piracicaba, 1988. 101 p. Dissertação (Mestrado) - Escola Superior de Agricultura Luiz de Queiroz, Universidade de São Paulo.

BELTRÃO, N.E. M.; SOUZA, J.G. Fisiologia e ecofisiologia do algodoeiro In: Embrapa Agropecuária Oeste. Algodão: tecnologia de produção. Dourados: Embrapa Agropecuária Oeste, 2001. p. 54-75.

BENEDICT, C.R. Physiology. In: KOHEL, R.J.; LEWIS, C.F. (Ed.). Cotton. Madison: American Society of Agronomy, 1984. p. 151-200.

BERGAMIN FILHO, A. Curvas de progresso da doença In: BERGAMIN FILHO, A.; KIMATI, H.; AMORIN, A. Manual de fitopatologia. $3^{\text {a }}$ ed. São Paulo: Agronômica Ceres, 1995. v.1, p. 602-625.

BERGAMIN FILHO, A.; AMORIM, L. Doenças de plantas tropicais: epidemiologia e controle. São Paulo: Ed. Agronômica Ceres, 1996. 289p.

CHIAVEGATO, E.J. Efeito do ambiente e de cultivares nos componentes da produção e nas características tecnológicas da fibra e do fio de algodão. Piracicaba, 1995. 115 p. Tese (Doutorado) - Escola Superior de Agricultura Luiz de Queiroz, Universidade de São Paulo.

CHIAVEGATO, E.J. Importância potencial de doenças do algodoeiro nas regiões produtoras do Brasil. Apresentado ao 3. Congresso Brasileiro de Algodão, Campo Grande, 2001.

CIA, E.; GRIDI-PAPP, I.L.; CHIAVEGATO, E.J.; SABINO, N.P.; KONDO, J.I.; PIZZINATO, M.A.; BORTOLETTO, N.; CARVALHO, L.H. Melhoramento do algodoeiro no Estado de São Paulo: Obtenção da Cultivar IAC 21. Bragantia, v. 60, 
n. 1, p. 9-17, 2001.

CIA, E.; SALGADO, C.L. Doenças do algodoeiro (Gossypium spp.). In: BERGAMIM FILHO, A.; KIMATI, H.; AMORIM, L. Manual de fitopatologia. São Paulo: Agronômica Ceres, 1995. Vol 2: Doenças das Plantas Cultivadas, p. 331-341.

CIA, E.; FUZATTO, M.G. Algodoeiro “IAC-23": um passo no árduo caminho para atingir a resistência múltipla a doenças. Campinas: IAC, 2002. 3p. (Relatório Técnico)

CIA, E.; FUZATTO, M.G. Manejo de doenças na cultura do algodão. In: CIA, E.; FREIRE, E.C.; SANTOS, W.J. (Ed.) Cultura do algodoeiro. Piracicaba:Potafós, 1999. p. 121-131.

CIA, E; FUZATTO, M.G.; GRIDI-PAPP, I.L.; SOAVE, J. Avaliação da intensidade da ramulose do algodoeiro através de inoculação artificial. In: REUNIÃO NACIONAL DO ALGODÃ̃, 2, Salvador, 1982. Resumos. Campina Grande: Embrapa Algodoeiro, p. 241.

COHEN, Y; ROTEM, J. Sporulation of foliar pathogens. In: PEGG, G.F.; AYRES, P.G. (ed.) Fungal infection of plants. Cambridge, Cambridge University Press, 1988. p. 314-333.

Cooperativa Central Agropecuária de Desenvolvimento Tecnológico e Econômico (COODETEC). Guia técnico de cultivares de algodão 1999/2000. Cascavel, , 1999. $16 \mathrm{p}$.

COSTA, A.S. Investigações sobre a ramulose. Campinas: Instituto Agronômico, 1941. 42p. (Relatório da Seção de Algodão).

DOORENBOS, J.; KASSAN, A.H.; BENTVELSEN, C.L.M.; BRANSCHEID, V.; PLUSJÉ, J.M.G.A.; SMITH, M.; UITTENBOAGAARD, G.O.; VAN DER VAL, H.K. Efectos del agua sobre el rendimiento de los cultivos. Roma: FAO, 1979. 212p. (FAO. Riego y Drenaje, 33).

DRUMMOND, O.A. A ramulose em Minas Gerais. Boletim da Agricultura, v. 10, n. 3, p. 95-97, 1691.

EVERSMEYER, M.G.; BURLEIGH, J.R. A method of predicting epidemic development of wheat leaf rust. Phytopathology, v. 60, p. 805-811, 1970.

FNP Consultoria \& Comércio. Agrianual 2002: anuário estatístico da agricultura brasileira. São Paulo. p. 141-154: 2002. Algodão. Programas incentivam a cotonicultura no Mato Grosso e Bahia.

GASPAROTTO, L.Epidemiologia do mal da folhas (Microcylus ulei (P. Henn) v. Arx) da 
seringueira (Hevea spp.). Viçosa, 1988. 124 p. Tese (Doutorado) - Universidade Federal de Viçosa.

GILLESPIE, T. J.; KIDD, G. E. Sensing duration of leaf moisture retention using electrical impedance grids. Canadian Journal of Plant Science. V. 58, p. 179-187, 1978.

GOULART, A.C.P. Tratamento de sementes do algodoeiro com fungicidas. In: Embrapa Agropecuária Oeste. Algodão: tecnologia de produção. Dourados: Embrapa Agropecuária Oeste, 2001. p. 140-158.

GROVE, G.G.; MADDEN, L.V.; ELLIS, M.A. SCHMITTHERNNER, A.F. Influence of temperature and wetness duration of infection of immature strawberry fruit by Phytophthora cactorum. Phytopathology, v. 75, p. 165-166, 1985.

HAYMAN, D.S. The influence of temperature on the exudation of nutrients from cottonseeds and on preemergence damping off by Rhizoctonia solani. Canadian Journal of Botany, Ottawa, v.47, p.1663-1669, 1969.

HEARN, A.B. Crop physiology. In: ARNOLD, M.H. (Ed.). Agricultural research for development: the namulongue contribution. London: Cambridge University Press, 1973. p. 76-122.

HEITHOLT, J.J. Canopy characteristics associated with deficient and excessive cotton plant population densities. Crop Science, v. 34, n. 5, p. 1291-1297, Sep./Oct. 1994.

HEITHOLT, J.J.; MEREDITH Jr., W.R.; WILLIFORD, J.R. Comparison of cotton genotypes varying in canopy characteristics in $76-\mathrm{cm}$ vs. 102-cm rows. Crop Science. v. 36, p. 955-960, 1996.

HOSFORD, R.M.; LAREZ, C.R.; HAMMOND, J.J. Interaction of wet period and temperature on Pyrenophora tritici-repentis infection and development in wheats of differing resistance. Phytopathology, v. 77, n. 7, p. 1021-1027, 1987.

HUNTER, R.E.; GUINN, G. Effect of root temperature on hypocotyls of cotton seedlings as a source of nutrition for Rhizoctonia solani. Phytopathology, v.58, p.981-984, 1968.

JADHAO, J.K.; DEGAONKAR, A.M.; NARKHEDE, W.N. Performance of hybrid cotton cultivars at different plant densities and nitrogen levels under rain fed conditions. Indian Journal of Agronomy, v. 38, p. 340-341, 1993.

JOST, P.H.; COTHREN, J.T. Growth and yield comparisons of cotton planted in conventional and ultra-narrow row spacings. Crop Science, v. 40, n. 2, p. 430-435, Mar./Apr. 2000. 
KERBY, T.A.; CASSMAN, K.G.; KEELEY, M. Genotypes and plant densities for narrow-row cotton systems. I. Height, nodes, earliness, and location of yield. Crop Science v. 30, p. 664-649. 1990a.

KERBY, T.A.; CASSMAN, K.G.; KEELEY, M. Genotypes and plant densities for narrow-row cotton systems. II. Leaf area and dry-matter partitioning. Crop Science v. 30, p. 664-649. 1990 b.

KERBY, T.A.; CASSMAN, K.G.; URIE, L.; KEELEY, M. Phenotypes and a production system for high yielding 30-inch. P. 119-120. In: BROWN, J.M. Beltwide Cotton Producers Res. Conference, New Orleans, L.A. 1988.

KIMATI, H. Doenças do algodoeiro - Gossypium spp. In: GALLI, F.(coord.) Manual de fitopatologia. São Paulo: Ceres, 1980. v.2, p.29-48.

KRANZ, J. Measuring plant disease. In: KRANZ, J.; ROTEM, J. (Eds.) Experimental techniques in plant disease epidemiology. Berlin: Springer-Verlag, 1988, 299p.

KRANZ, J.; HAU, B. Systems analysis in epidemiology. Annual Review of Phytopathology. V. 18, p. 67-83. 1980.

KRUGNER, T.L. Ação do ambiente sobre doenças de plantas. In: GALLI, F.(coord). Manual de fitopatologia. São Paulo: Ceres, 1978. v.1, p. 215-266.

LACA-BUENDIA, J.P.; FARIA, E.A. Manejo e tratos culturais do algodoeiro. Informe Agropecuário, v. 8, n. 92, p. 50-61, ago. 1982.

LAMAS, F.M.; STAUT, L.A. Espaçamento e densidade In: Embrapa Agropecuária Oeste. Algodão: tecnologia de produção. Dourados: Embrapa Agropecuária Oeste, 2001. p. 135-139.

LAZZAROTTO, C.; ARANTES, E.M.; LAMAS, F.M. Época de semeadura e zoneamento agrícola In: Embrapa Agropecuária Oeste. Algodão: tecnologia de produção. Dourados: Embrapa Agropecuária Oeste, 2001. p. 124-134.

LENNÉ, J.M.; SONODA, R.M.; PARBERY, D.G. Production of conidia by setae of Colletotrichum species. Mycologia, v. 76, n. 2, p. 359 - 362, 1984.

LOPES, D.B; BERGER, R.D.; BERGAMIN FILHO, A. Absorção da área foliar sadia (HAA): uma nova abordagem para a quantificação de dano e para o manejo integrado de doença. Summa Phytopathologica, v. 20, p.143-151, 1994.

MACHADO, J.C. Padrões de tolerância de patógenos associados às sementes. In: LUZ, W.C. (Ed.). Revisão anual de patologia de plantas. Passo Fundo. v.2, p. 229-263, 1994. 
MACHADO, J.C. Patologia de sementes: fundamentos e aplicações. Brasília: MEC;FAEPE;ESAL, 1988. 107p.

MADDEN, L.V. Modeling yield losses at the field scale. In: International Congress of Plant Pathology, 6, Montreal, 1993. p.11. (Abstracts).

MADDEN, L.V. Quantification of disease progression. Protection Ecology, 1980. v. 2, p. $159-176,1980$.

MARIN, F.R.; ANGELOCCI, L.R.; COELHO FILHO, M.A.; VILLA NOVA, N.A. Construção e avaliação de psicrômetro aspirado de termopar. Scientia Agrícola, v.58, n. 3, 2001.

MAUNEY, J.R. Anatomy and morphology of cultivated cottons. In: KOHEL, R.J.; LEWIS, C.F. (Ed.). Cotton. Madison: American Society of Agronomy, 1984. p. 5980 .

MENDES, B.M.J. Influência de parâmetros de clima e do hospedeiro no desenvolvimento da ferrugem do feijoeiro (Uromyces phaseoli var. typica Arth.). Piracicaba, 1987. 102 p. Tese (Doutorado) - Escola Superior de Agricultura Luiz de Queiroz, Universidade de São Paulo.

OOSTERHUIS, H.J.W. Growth and development of cotton plant In: CIA, E.; FREIRE, E.C.; SANTOS, W.J. (Ed.) Cultura do algodoeiro. Piracicaba:Potafos, p. 35-56, 1999.

ORTOLANI, A.A. Contribuição ao estudo ecológico da ferrugem do cafeeiro (Hemilea vastatrix Berk et Br.) em diferentes populações de Coffea arábica L. da região de Pindorama - Sp, Brasil. Botucatu, 1973. Tese (Doutorado) - Faculdade de Ciencias Médicas e .Biológicas de Botucatu., Universidade Estadual Paulista "Júlio de Mesquita Filho".

PAIVA, F.A.; ASMUS, G.L.; ARAÚJO, A.E. Doenças In: Embrapa Agropecuária Oeste. Algodão: tecnologia de produção. Dourados: Embrapa Agropecuária Oeste, 2001. p. 245-272.

PEDRO JR., M.J. Aspectos microclimáticos e epidemiologia. In: Curso prático internacional de agrometeorologia para a otimização da irrigação, 3. Campinas, Instituto Agronômico, 1989. 13p.

PEDRO JR., M.J.; PEZZOPANE, J.E.M.; ALFONSI, R.R.; MARTINS, F:P. Duração do período de molhamento em videira. In: CONGRESSO BRASILEIRO DE AGROMETEOROLOGIA, 7., Viçosa, 1991. Resumos. Viçosa: UFV, SBA, 1991. p.151-153.

PEREIRA, A.R.; ANGELOCCI, L.R; SENTELHAS, P.C Agrometeorologia: 
fundamentos e aplicações práticas. Guaíba: Agropecuária, 2002. 478p.

ROTEM, J. Climatic and weather influences on epidemics. In: HORSFAL, J.G.; COWLING, E.B. (Ed.) Plant disease. An advanced treatise. New York: Academic Press, 1978. v. 2, p. 317-334.

ROTEM, J. Techniques of controlled condition experiments. In: Kranz J.; Rotem J. (Eds.) Experimental techniques on plant disease epidemiology. Berlin: SpringerVerlag. 1988. p. 279-289.

ROTEM, J.; PALTI, J. Irrigation and plant disease. Annual Review of Phytopathology, v. 7, p. 267-288, 1969.

ROYLE, D.J.; BUTLER, D.R. Epidemiological significance of liquid water in crop canopies and its role in disease forecasting. In: AYRES, P.G.; BODDY, L. (Ed.) Water, fungi and plants, Cambridge: University Press, 1986. p. 139-156.

SANTOS, G.R. Progresso da ramulose do algodoeiro e transmissão de Colletotrichum gossypii South. var. cephalosporioides Costa pelas sementes. Viçosa:, 1993. 53p. Dissertação (Mestrado), Universidade Federal de Viçosa.

SENTELHAS, P.C. Ocorrência de helmintosporiose (Helminthosporium sativum) e de oídio (Erysiphe graminis) na cultura do trigo (Triticum aestivum, L.) sob diferentes condições microclimáticas. Piracicaba, 1992. 103p. Dissertação (Mestrado) Escola Superior de Agricultura Luiz de Queiroz, USP.

SILVA, N.M. Estudo da influência de fatores meteorológicos sobre o ciclo e a produção do algodoeiro ( $G$. hirsutum L.). Piracicaba, 1972. 45p. Tese (Doutorado) Escola Superior de Agricultura Luiz de Queiroz, USP.

STAUT, L.A.; LAMAS, F.M. Arranjo de plantas e época de semeadura para a cultura do algodoeiro. In: CONGRESSOS BRASILEIROS DE ALGODÃO, 2. Ribeirão Preto, 1999. Anais . Campina Grande: EMBRAPA, CNPA, 1999. p. 649-651.

SUTTON, J.C.; GILLESPIE, T.J.; HILDEBRAND, P.D. Monitoring weather factors in relation to plant disease. Plant Disease, v. 68, n. 1, p. 78-84, 1984.

TANAKA, M.A.S. Patogenicidade e transmissão por sementes do agente causal da ramulose do algodoeiro. Piracicaba: ESALQ, 1990. Tese (Doutorado) Escola Superior de Agricultura Luiz de Queiroz, USP.

TANAKA, M.A.S. Transmissão planta - semente e semente - plântula do agente causal da ramulose do algodoeiro. In: MENTEN, J.O.M. Patógenos em sementes: detecção, danos e controle químico. Piracicaba: ESALQ/FEALQ, p. 171-178, 1995.

TEIXEIRA, H. Colletotrichum gossypii South. em sementes de algodoeiro (Gossypium 
hirsutum L.): Transmissibilidade e controle. Lavras: ESAL, 1995. 74p. Dissertação (Mestrado) Escola Superior de Agricultura de Lavras.

THOMPSON, W.R. Cotton production for high yields and quality. In: CIA, E.; FREIRE, E.C.; SANTOS, W.J. Cultura do algodoeiro. Piracicaba:Potafós, 1999. p. 9-14

TORMELIN, J.R.; EVERSMEYER, M.G.; KRAMER, C.L.; BROWDER, L.E. Environmental and host effects on latent and infections periods and on urediniospore production of Puccinia recondita f.sp. tritici. Phytopathology, v. 73, p. 414-419, 1983.

TORMELIN, J.R.; JONES, A.L. Effect of temperature and relative humidity on the latent period of Venturia inaequalis in apple leaves. Phytopathology, v. 73, p. 51-54, 1983.

VALE, F.X.R.; ZAMBOLIN, L. Influência da temperatura e umidade nas epidemias de doenças de plantas. Revisão Anual de Patologia de Plantas, v. 4, p. 149-207, 1996.

WANG, H.; DAVIS, R.M. Susceptibility of selected cotton cultivars to seedling disease pathogens and benefits of chemical seed treatments. Plant Disease, v. 81, n. 9, p. 1085-1088, Mar. 1997.

WATKINS, G.M. (Ed.). Compendium of cotton diseases. St. Paul: APS, 1981. 87p.

YARWOOD, C.E. Humidity requirements of foliage pathogens. Plant Disease Reporter, v. 58, n. 2, p. 133-135, 1956.

ZADOKS, J.C. On the conceptual basis of crop loss assessment: the threshold theory. Annual Review of Phytopathology, v.23, p.455-473, 1985.

ZADOKS, J.C.; SCHEIN, R.D. Epidemiology and plant disease management. Oxford: University Press, 1979. 427p.

ZALHER, D.M.; MOTA, F.S.; AGENDES, M.O.O. Previsão agrometeorológica no controle de doenças e pragas. Brasília: Ministério da Agricultura e Reforma Agrária, 1991. 54p. 